LEGAL MATERIALS 
B.S. Chimni, Miyoshi Masahiro, and Thio Li-ann - 9789047423904 Downloaded from Brill.come4/26/2023 03:50:24AM via free access 


\title{
STATE PRACTICE OF ASIAN COUNTRIES IN THE FIELD OF INTERNATIONAL LAW
}

\author{
CHINA
}

\section{JUDICIAL DECISIONS $^{1}$}

\begin{abstract}
Maritime Claims under Chinese Law - Relevant International Convention Application of International Maritime Dangerous Goods Code
\end{abstract}

\author{
NEW NATIONAL ASSURANCE COMPANY LTD. v. SHANGHAI RIJIN-TOP \\ EXPRESS INTERNATIONAL FORWARDING CO. LTD.
}

\section{Shanghai Maritime Court of PRC (SMC), 21 April 2005 \\ Civil Judgment (2004) TMC (Chu) No. 492}

Facts

On 15 September 2003, the defendant issued a Bill of Lading (B/L) numbered as DNB030909. Shipper: Auto Best Co. Ltd.; Consignee and Notify Party: Danny's Automotive Company; Cargo: Spare Tools and Accessories; No. of Pieces: 1,183 (Container GATU8063730); Port of Lading: Ning Bo, China; Destination: Johannesburg; Shipment: KOTA WAJAR 087; Freight to Collect.

According to a Marine Cargo Transportation Insurance Contract (No. 2199080) between the plaintiff and a company named Prologistics, claimed by the plaintiff as the agent of Danny's Automotive Company, Prologistics appeared as an insured

\footnotetext{
* Edited by B.S. Chimni and Joydeep Narayan Choudhuri. The years for which the State Practice has been collated are 2004 and 2005. However, in some instances, prior state practice has been included. This editorial decision was taken for two reasons: first, that readers may find useful the state practice of previous years; second, that often this previous state practice is available only in later years. The responsibility for the content of a contribution is that of each national contributor to the State Practice Section. The original footnote form has been retained in each contribution.

${ }^{1}$ Contributed by Yun Zhao, Assistant Professor, City University of Hong Kong.
} 
party in the Contract. The plaintiff initiated the suit based on his subrogation rights, which were valued in toto at USD 67,874.76.

On 21 October 2003, the container GATU8063730 was confirmed as being totally lost in a fire on board the ship the Sea Elegance. The report by the Maritime Security Bureau of South Africa testified that a container with 20 tons of Calcium Hypochlorite (hereinafter $\mathrm{CH}$ ) was neither declared nor labelled as dangerous cargo in Singapore, was not loaded appropriately, and it eventually exploded. The $\mathrm{CH}$ container was loaded onto the bottom floor of the larboard, beside a container of HO. In the same cabin, there were containers of plastics, rubber- and paper-based cargoes; the adjacent cabin was the engine room. In the International Maritime Dangerous Goods Code (hereinafter IMDG), $\mathrm{CH}$ is listed as dangerous goods (No. 1748, level 5.1). According to the regulations issued by the United Nations Maritime Organization on IMDG, this kind of dangerous shipping unit shall be loaded on the deck cabin, avoiding excessive sunlight and heat sources, and the packages should be stacked reasonably allowing adequate ventilation. The International Salvage Union and the International Group of P\&I suggested that the $\mathrm{CH}$ can only be loaded on the deck and the chemical cargoes shall be packed in drums each containing no more than 45 kilograms. If the air temperature is higher than $35^{\circ}$ Celsius, the shipper should take measures to lower the temperature of the container of No. 1748 cargoes in IMDG, or each container should not contain over 14 tons of those goods. From the investigation it has been evident that in temperatures of over $35^{\circ}$ Celsius, the $\mathrm{CH}$ will become unstable and can possibly result in a fire or in an explosion. The experts reached a consensus that the explosion and fire on the Sea Elegance were caused by the unstable $\mathrm{CH}$ in the circumstance of an air temperature of over $35^{\circ}$ Celsius.

The Judgment

The Court rejected the Plaintiff's request by citing Articles 51 and 269 of the Maritime Code of the People's Republic of China, as well as Article 54 of the Civil Procedure Code of the People's Republic of China.

The accident was caused by the negligence of the CH's consignor. He failed to declare and to label the container as dangerous goods as defined in the IMDGC, which caused the improper loading and eventually resulted in fire and explosion. The consignors/shippers should have been more aware of the features of the goods than was the carrier. They were obligated to remind the carrier to pay attention to the character of the cargo and to take measures to prevent, and if necessary deal with, possible accidents. If a shipper failed to fulfil this obligation, he would be found responsible for any damage. In this case, the carrier loaded the cargoes unwittingly, so he and his employees were not negligent as regards the cause of the fire accident.

Even if the loss of the goods was because of the inappropriate loading by the employees of the carrier, the plaintiff would not be entitled to damages for there is a special rule in the legislations. According to the law as per Article 51 of the Maritime Code of the People's Republic of China, unless caused by the actual fault of the carrier, the carrier will not be liable for the loss of or damage to the goods incurred during the period of the carrier's responsibility arising or resulting from 
a fire. The evidence provided by the plaintiff did not prove the existence of the actual fault of the carrier himself, so the carrier was exempted from the responsibility for the damages caused in the fire. The plaintiff did not justify his request for damages on the basis of inappropriate loading.

Application of the New York Convention on Recognition and Enforcement of
Foreign Arbitral Awards, 1958 - Application for recognition and enforcement

VYSANTHI SHIPPING COMPANY LTD. v. CHINA GRAINS, OILS \& FEEDSTUFFS CO. LTD. AND OTHERS

Tianjin Maritime Court of PRC (TMC), 29 October 2004

Civil Order in Writing (2004) TMC (Que) No.1

Facts

The dispute between the applicant and the first defendant on the $\mathrm{B} / \mathrm{L}$ of the Joanna V Ship issued on 28 June 1996 had been heard by the London Court of International Arbitration (LCIA) and an award was issued on 14 March 2001. According to the award, the applicant should obtain USD 367,136.86 in general average contribution (GAC) and USD 28,500 in damages of resorting. The applicant should also obtain interest at seven per cent per annum on the above amount. The interest on damages of resorting (USD 28,500) would be calculated from 1 August 1996. The commencement time for calculating the GAC interest would, however, depend on the results of the negotiation between the applicant and the first defendant. If their negotiation failed, the arbitration court would decide the date. The end dates of the interest of both damages would be the day when the first defendant made the de facto payment to the applicant. On 20 June 2001, the LCIA made the second award, stating that the date of commencement for calculating the interest of the resorting damages should be 12 July 1996. In the same award, it was stated that the arbitration fees for the two arbitration procedures would be paid by the first defendant. On 13 February 2002, the third award was made to confirm that the cost of the whole dispute should be paid by the first defendant.

On 28 March 2002, the first defendant and the second defendant brought an action before the Commercial Court of the Queen's Bench Division, applying for the setting aside of the above awards. On 10 July 2002, the court ruled that the defendants should perform as the award decided. On 17 January 2004, the Tianjin Maritime Court received the applicant's application for recognizing and enforcing the above three awards.

The Judgment

The court did not recognize and enforce the three awards brought forward by the applicant. These awards were made by the LCIA on 14 March 2001, 20 June 
2001, and 13 February 2002, respectively. The applicant would pay the litigation fee (RMB 500).

The United Kingdom and the People's Republic of China are both parties to the 1958 New York Convention on Recognition and Enforcement of Foreign Arbitral Awards. In line with the Convention and the relevant provisions in the law of People's Republic of China, arbitral awards made in the United Kingdom shall be recognized and enforced in the People's Republic of China. The Civil Procedure Law of the People's Republic of China rules in Article 219 and states as follows: "The time limit for the submission of an application for execution shall be one year, if both or one of the parties are citizens; it shall be six months if both parties are legal persons or other organizations." The Tianjin Maritime Court received the written application on 17 January 2004. Although the date when the awards were received by the parties was not clear and the time period for the performance of the awards was also not clear, the fact that the defendants brought the action before the British court on 28 March 2002 clearly proved that the first and second defendants, as well as the applicant, received the awards before that day. The application for recognition and enforcement had been overdue. The judgment of the British court was that the circumstances did not consist of a reasonable excuse for extending and/or breaking off the calculation of the six-month time limit during which one can successfully apply for the recognition and enforcement of foreign arbitral awards.

\section{Application of the 1993 Uniform Customs and Practice for Documentary Credits - Reimbursement under Letter of Credit}

INDUSTRIAL BANK OF KOREA v. QINGDAO HUATIAN HANDTRUCK CO. LTD. \& TIANJIN BRANCH OF THE INDUSTRIAL BANK OF KOREA CO. LTD. $^{2}$

\section{Shandong Higher People's Court, 15 December 2005 (2005) Lu Min Si Zhong Zi No. 71}

Facts

'A', the Industrial Bank of Korea, issued an Irrevocable Documentary Credit numbered M04Z9403NU30011, whose beneficiary was 'D', the Qingdao Huatian Handtruck Co. Ltd. On the Documentary Credit it was stated that the expiry date/place was 10 May 2005/China, the amount was USD 23,900 payable at any bank, the deadline of payment was 90 days after sight, and the latest shipment date was 30 April 2004. The Documentary Credit also required documents such as the commercial invoice, the full set of the clean on board marine bill of lading, the packing list, the certificate of origin, etc. The period for the presentation of documents was within

\footnotetext{
2 Source: <http://www.ccmt.org.cn/ss/writ/judgementDetial.php?sId=1845>.
} 
ten days after the date of issuance, and did not exceed the expiry date of the Documentary Credit. The documents mentioned above were submitted together with a sight draft of USD 23,900 to 'A' on 14 April 2004. However, on 27 April 2004, ' $A$ ' refused to pay, and the reason stated in its telegram was that the draft was a sight draft, not payable 90 days after sight. On 10 May 2004, a draft payable 90 days after sight was sent to ' $A$ ', but 'A' again refused to reimburse by telefax; the reason given was that the period for presentation of documents had expired. After several unsuccessful approaches and negotiations, on 5 November 2004, 'A' replied, "Though there are factors not satisfying the requirements to pay, we are willing to reimburse half of the amount (i.e., USD 11,950). If you agree, please acknowledge us by SWIFT." Both parties, however, failed to reach an agreement on the payment.

The Judgment

Pursuant to Section 1(1) of Article 153 of the Civil Procedure Law of the People's Republic of China, the appellate court held that the appeal is dismissed, and the original judgment is affirmed. The litigation costs for the appeal case are RMB 5588, and they shall be paid by 'A'.

Since ' $A$ ' and the Tianjing Branch of the Industrial Bank of Korea Co. Ltd. (hereinafter "B") are a Korean corporation and its branch, the present case is a commercial case concerning foreign interests. Therefore, the provisions of the Civil Procedure Involving Foreign Interests should be applied. Since both the beneficiary's domicile and the issuing bank's domicile are the place of performance of the contract of documentary credit, D's domicile is also one of the places of performance. Therefore, the trial court has jurisdiction in the present case as the contract's place of performance is under the jurisdiction of the appellate court. Further, the parties to the case have reached an agreement to apply the Uniform Customs and Practice for Documentary Credits (1993 edition, hereinafter "UCP500") as the applicable law.

The main issue in the present case is whether A's reason for refusing to reimburse was valid. According to the provisions stipulated in the chapter of the "Documents" of the UCP500, drafts are not included in the definition of "documents". Therefore, unless there are special stipulations in the Documentary Credit clause, drafts are generally not documents in the sense of Documentary Credits. However, in the present case, there were special clauses on drafts. Since the Documentary credit is the contract between the issuing bank and the beneficiary, the parties should be bound by the clauses of the contract. Therefore, D's first draft did not appear on its face to be in compliance with the terms and conditions of the Credit; it constitutes an alteration to the original contract, and ' $\mathrm{A}$ ' had the right to refuse to accept it. In this sense, A's reason for refusing to pay was valid. However, since the draft is not a kind of "document", its presentation should not be limited by the aforementioned deadline. Therefore, A's reason for the second refusal to pay was not valid, and the trial court should support D's claims to USD 23,900 and the interest accrued. 
NATIONAL LAWS ON INTERNATIONAL LAW MATTERS ${ }^{3}$

\section{Special Marine Reserves \\ Interim Measures for the Administration of Special Marine Reserves}

In November 2005, Interim Measures for the Administration of Special Marine Reserves were promulgated in accordance with Article 23 of the Marine Environment Protection Law of the People's Republic of China (as revised in 1999) which stipulates:

Wherever there exist special geographical conditions or ecosystem, or special need for exploitation and utilization of biological and non-biological resources, special marine reserves should be established for special administration with effective protection measures and scientific exploitation mode.

The scope of application of this Decree is limited to the sea areas under the jurisdiction of the People's Republic of China. ${ }^{4}$

\section{Fishery Administrative Cruising within Exclusive Economic Zones Provisions on the Administration of Fishery Administrative Cruising within Exclusive Economic Zones}

Fishery administrative cruising started in the year 2000 in China upon the promulgation of the "Provisions on the Administration of Fishery Administrative Cruising within Exclusive Economic Zones (No. 8 [2000] of the BFMFPS)." Change of circumstances as well as the accumulation of experience in fishery administrative cruising in the following years called for a revision of the 2000 Provisions.

The change of circumstances includes the conclusion of fishery agreements with Japan and Korea (coming into force on 1 June 2000 and 30 June 2001, respectively). A substantial revision of the Provisions on the Administration of Fishery Administrative Cruising appears in Article 21, which extends the fishery administrative cruising to the high seas. It also confirms, in light of the Sino-Japanese Fishery Agreement and the Sino-Korean Fishery Agreement, administrative cruising in areas such as sea waters subject to temporary measures, transitional sea areas or condominium sea areas.

\footnotetext{
${ }^{3}$ Contributed by Zhang Xinjun, School of Law, Tsinghua University, Beijing, China

${ }^{4}$ For the text of the Chinese version of the Decree No. 24 (2005) of the State Oceanic Administration promulgated on 16 November 2005, see the official website of the State Oceanic Administration of the People's Republic of China < http://www.soa.gov.cn/bbs/060117.doc > (accessed 15 June 2006).
} 


\title{
Excerpt from Provisions on the Administration of Fishery Administrative Cruising within Exclusive Economic Zones ${ }^{5}$
}

\section{[No. 83 (2005) of China Fishery Administration Commanding Centre]}

\author{
[Date of Promulgation: 14 November 2005] \\ [Effective date: 14 November 2005]
}

Article 1. The present Provisions are formulated in accordance with the Fishery Law of the People's Republic of China and other laws and regulations in order to regulate and strengthen the administration of fishery administrative cruising, and to maintain the normal fishery production order as well as to maintain the marine rights and interests of the state in exclusive economic zones.

Article 2. The "fishery administrative cruising within exclusive economic zones" as mentioned in the present Provisions refers to the law enforcement whereby the fishery law enforcement authority, under the relevant laws and regulations of the state, sends out fishery administrative ships for carrying out supervision and inspection over and imposes an administrative penalty upon Chinese and foreign ships and persons that engage in fishery activities such as fishery production and survey of biological resources within the exclusive economic zones of China.

Article 8 . The main tasks for the fishery administrative cruising within exclusive economic zones shall be:

(1) Investigating and regulating foreign ships that illegally enter into the exclusive economic zones of China for fishery activities;

(2) Carrying out supervision and on-the-spot regulation of foreign ships that are allowed to engage in fishery industry or surveys of biological resources within the exclusive economic zones of China;

(3) Carrying out supervision over the implementation of bilateral or multilateral fishery agreements of domestic and foreign fishing ships within the jointly managed fishing areas as determined by the agreements concluded between China and the relevant countries, and carrying out on-the-spot regulation of domestic fishing ships, investigating and administrating illegal fishery acts;

(4) Observing and recording the activities of domestic and foreign fishing ships;

(5) Assisting the settlement of fishery disputes or maritime casualties between domestic and foreign fishing ships;

(6) Participating in the salvation of fishing ships to which maritime safety accidents occur, and

(7) Fulfilling other tasks as assigned by the CFACC and the fishery bureau for sea areas.

5 Unofficial translation. The Chinese version appears in Zhong Guo Shui Chan (China Fishery) No. 2 (2006), pp. 17-19. 
Article 15. The visiting and inspection of foreign ships shall be conducted by following the prescribed visiting and inspection procedures. The investigation and regulation of foreign ships that violate the law shall be conducted in pursuance of the Interim Provisions on the Administration of Fishery Activities of Foreign Persons and Ships on Sea Areas Subject to the Jurisdiction of the People's Republic of China (Order No. 18 [1999] of the Ministry of Agriculture) and the Notice on Specific Handling Procedures for Fishery Cases Involving Foreign Persons and Ships (No. 11 [1999] of the Bureau of Fishery Management and Fishing Port Superintendence of the People's Republic of China).

Article 21 . The fishery administrative cruising in the high seas, sea waters subject to temporary measures, transitional sea areas or condominium sea areas as prescribed by the fishery agreements concluded between China and other countries shall be conducted in accordance with the present Provisions.

Article 22. The power to interpret the present Provisions shall remain with the Bureau of Fishery Management and Fishing Port Superintendence of the People's Republic of China.

Article 23. The present Provisions shall come into force as of the date of promulgation, and the original Notice of the BFMFPS on Printing and Distributing the Provisions on the Administration of Fishery Administrative Cruising within Exclusive Economic Zones (No. 8 [2000] of the BFMFPS) shall be simultaneously repealed.

\section{Revising Implementation of the Clean Development Mechanism Projects under Article 12 of the Kyoto Protocol to the United Nations Framework Convention on Climate Change \\ Measures for Operation and Management of the Clean Development Mechanism (CDM) Projects}

On 31 May 2004, the People's Republic of China promulgated the decree "Interim Measures for Operation and Management of Clean Development Mechanism Projects" (Interim Measures). ${ }^{6}$ The "Interim Measures" were modified by the "Measures for Operation and Management of Clean Development Mechanism Projects," promulgated on 12 October 2005. Although modification was limited to the minimum extent, a substantial change made in the new regulation is "benefit sharing" under Article 24. Under the "Interim Measures", the Chinese Government would retain the benefit from project owners in selling Certified Emission Reductions (CERs). However, the manner of "benefit sharing" was not specified. The new Article 24 sets up criteria for collecting fixed portions of revenue from different types of CDM projects.

\footnotetext{
6 The full text of the "Interim Measures" appears in the "State Practice of Asian Countries in the Field of International Law” section of the Asian Yearbook of International Law, Vol. 11 (2003-2004).
} 


\section{Excerpt from Measures for Operation and Management of Clean Development Mechanism (CDM) Projects ${ }^{7}$}

[Order No. 37 (2005) Ministry Order of National Development and Reform Commission, Ministry of Science and Technology, Ministry of Foreign Affairs, and Ministry of Finance]

[Date of Promulgation: 12 October 2005]

[Effective Date: 12 October 2005]

Article 24. Whereas emission reduction resource is owned by the Government of China and the emission reductions generated by a specific CDM project belong to the project owner, revenue from the transfer of CERs shall be owned jointly by the Government of China and the project owner, with the allocation ratio defined as below:

(1) the Government of China takes 65 per cent CER transfer benefit from HFC and PFC projects;

(2) the Government of China takes 30 per cent CER transfer benefit from the $\mathrm{N} 2 \mathrm{O}$ project;

(3) the Government of China takes two per cent CER transfer benefit from CDM projects in priority areas defined in Article 4 and forestation projects.

The revenue collected from CER transfer benefits of CDM projects will be used in supporting activities on climate change. The detailed regulations on the collecting and using of the revenue will be formulated by the Ministry of Finance jointly with the NDRC and other relevant departments.

(4) The Article does not apply to the projects already approved by the Government of China before 12 October 2005.

Immunity of Properties of Foreign Central Banks against Judicial Compulsory Measures

Law of the People's Republic of China on the Immunity of Judicial Compulsory Measures against the Properties of Foreign Central Banks

China has long maintained the position of supporting the doctrine of State immunity which bars a national court from adjudicating or enforcing claims against foreign States and their properties. The Chinese judicial practice is also consistent with that position. The Chinese court does not adjudicate or enforce claims relevant to properties of foreign central banks. Nevertheless, there has as yet been no legislation on the matter.

\footnotetext{
7 The Chinese text of the updated regulation can be viewed on the official website of the NDRC's (National Development and Reform Commission) Office of National Coordination Committee on Climate Change at <http://cdm.ccchina.gov.cn/UpFile/File538.PDF> (accessed 28 March 2006). The English version can also be viewed on the same official website $<$ http://cdm.ccchina.gov.cn/ english/NewsInfo.asp?NewsId=100> (accessed 28 March 2006).
} 
The request for legislation came from Hong Kong, a Special Administrative Region (SAR) of China since 1997. Before that, Britain's State Immunity Act applied in Hong Kong. It granted to foreign central banks immunity from adjudication and enforcement for their properties in Hong Kong. When the British administration terminated on 1 July 1997, the British law no longer applied; some foreign central banks in Hong Kong thus expressed their concerns that there was no statutory protection for their properties from adjudication and enforcement. It is under such circumstances and upon receiving the request from the Hong Kong SAR Government in 2000 that the Central Government of China passed the present legislation.

Text of Law of the People's Republic of China on the Immunity of Judicial Compulsory Measures against the Properties of Foreign Central Banks ${ }^{8}$ [Adopted at the 18th session of the Standing Committee of the Tenth National People's Congress of the People's Republic of China on 25 October 2005, Order of the President, No. 41 (2005)]

[Date of Promulgation: 25 October 2005]

[Effective date: 25 October 2005]

Article 1. The People's Republic of China grants to foreign central banks the immunity of judicial compulsory measures of protection and execution to their properties, unless the foreign central banks or the Governments of the countries to which the foreign central banks belong abandon this immunity in written form, or those properties are especially used for protection and execution.

Article 2. The term "foreign central banks" as mentioned in the Measures refers to the central banks of foreign countries and regional economic integration organizations, or those financial administrative organs performing the functions of central banks.

The term "properties of foreign central banks" as mentioned in the Measures refers to the cash, bills, bank deposits, securities, foreign exchange reserves, and gold reserves, as well as the real estate and other properties of foreign central banks.

Article 3. Where any foreign country does not grant the immunity to the properties of the central bank of the People's Republic of China or the properties of financial administrative organs of special administrative regions of the People's Republic of China, or grants an immunity which is lower than that as prescribed in this Law, the People's Republic of China shall handle it according to the principle of reciprocity.

Article 4. This Law shall come into force as of the date of promulgation.

\footnotetext{
8 Unofficial translation. The Chinese version appears in the Gazette of the Standing Committee of the National People's Congress of the People's Republic of China (2005, No. 8), published by the General Office of the Standing Committee on the National People's Congress.
} 


\title{
INDIA $^{9}$
}

\section{JUDICIAL DECISIONS}

\begin{abstract}
Implementation of domestic law on Prevention of Terrorism - Constitutional Validity of the Prevention of Terrorism Act - Scope and definition of 'Terrorism' - Terrorism and Human Rights - Security Council Resolutions 1368 (2001) and 1373 (2001)
\end{abstract}

PEOPLE'S UNION FOR CIVIL LIBERTIES AND ANOTHER v. UNION OF INDIA

Supreme Court of India, 16 December 2003

AIR 2004 Supreme Court 456

Facts

The Petitioners challenged the constitutional validity of certain provisions of the Prevention of Terrorism Act, 2002 (hereinafter POTA) contending that (a) the provisions of POTA fell under Entry 1 (Public Order) of List II (State List) of the Indian Constitution ${ }^{10}$ and accordingly the Indian Parliament lacked the legislative competence; (b) that terrorist activity and its regulation (essentially as a 'public order' concept) was within the realm of a State(s), and therefore State(s) only had the competence to enact legislation. The primary issue was whether acts of terrorism aimed at weakening the sovereignty and integrity of the country could be equated with mere breaches of public order or public safety.

The Judgment

“Terrorist acts", the Court noted, were

$[\mathrm{M}]$ eant to destabilize the nation by challenging its sovereignty and integrity, to raze the constitutional principles that we hold dear, to create a psyche of fear and anarchism among common people, to tear apart secular fabric, to overthrow democratically elected Government, to promote prejudice and bigotry, to demoralize the security forces, to thwart the economic progress and development and so on ... This cannot be equated with usual law and order problems within a State.

${ }^{9}$ Contributed by V.G. Hegde, Associate Professor, School of International Studies, Jawaharlal Nehru University, New Delhi.

${ }^{10}$ Article 246 of the Indian Constitution provides for the distribution of legislative powers between Union and States. The various matters of legislation have been enumerated in three lists: List I or the Union List; List II or the State List; List III or the Concurrent List. The Union Parliament has exclusive powers of legislation with respect to subjects or items in List I. The State Legislatures have exclusive powers to legislate on subjects or items in List II. The legislative power on items in List III is concurrent. 
Referring to the character of terrorism as "inter-state, inter-national or crossborder", the Court stated that it was not "a regular criminal justice endeavour". "Terrorism", it noted, "is definitely a criminal act, but it is much more than mere criminality",

Recognizing terrorism as a challenge to the whole community of civilized nations, the Court noted that terrorist activities in one country might take on a transnational character, carrying out attacks across one border, receiving funding from private parties or a Government across another, and procuring arms from multiple sources. Referring to domestic and international aspects of terrorism, the Court noted:

Terrorism in a single country can readily become a threat to regional peace and security owing to its spillover effects. It is, therefore, difficult in the present context to draw sharp distinctions between domestic and international terrorism. Many happenings in the recent past caused the international community to focus on the issue of terrorism with renewed intensity. The Security Council unanimously passed resolutions 1368 (2001) and 1373 (2001); the General Assembly adopted resolution 56/1 by consensus, and convened a special session. All these resolutions and declarations, inter alia, call upon Member States to take necessary steps to 'prevent and suppress the financing of terrorist acts'. India is a party to all these resolutions. Anti-terrorism activities [at] the global level are mainly carried out through bilateral and multilateral co-operation among nations. It has thus become our international obligation also to pass necessary laws to fight terrorism.

The Court also referred to the Report of the Policy Working Group on the United Nations and Terrorism which urged the global community to concentrate on a triple strategy to fight terrorism. These strategies, as noted by the Court, were (a) to dissuade disaffected groups from embracing terrorism; (b) to deny groups or individuals the means to carry out acts of terrorism, and (c) to sustain broad-based international cooperation in the struggle against terrorism. Based on these, the Court averred:

Therefore, the anti-terrorism laws should be capable of dissuading individuals or groups from resorting to terrorism, denying the opportunities for the commission of acts of terrorism by creating [an] inhospitable environment for terrorism and also leading the struggle against terrorism. Anti-terrorism law is not only a penal statute but also focuses on pre-emptive rather than defensive State action.

On the issue of balancing the protection and promotion of human rights, on the one hand, with the combating of terrorism within the Constitutional mandate, the Court stated:

The protection and promotion of human rights under the rule of law [are] essential in the prevention of terrorism. Here comes the role of law and Court's responsibility. If human rights are violated in the process of combating terrorism, it will be self-defeating. Terrorism often thrives where human rights are violated, which adds to the need to strengthen action to combat violations of human rights. The lack of hope for justice 
provides [the] breeding grounds for terrorism. Terrorism itself should also be understood as an assault on basic rights. In all cases, the fight against terrorism must be respectful to human rights. Our Constitution laid down clear limitations on State actions within the context of the fight against terrorism. To maintain this delicate balance by protecting 'core' Human Rights is the responsibility of [the] Court in a matter like this. The constitutional soundness of [the] POTA needs to be judged by keeping these aspects in mind.

The Court also had to deal with the legality and constitutional validity of the POTA provisions relating to the forfeiture of property of any person prosecuted and ultimately convicted. ${ }^{11}$ On this issue, the Court noted that:

Funding and financing play a vital role in fostering and promoting terrorism, and it is only with such funds that terrorists are able to recruit persons for their activities and make payments to them and their family to obtain arms and ammunition for furthering terrorist activities and to sustain the campaign of terrorism. Therefore, seizure, forfeiture and attachment of properties are essential in order to contain terrorism and are not unrelated to the same. Indeed, it is relevant to notice a resolution passed by the United Nations Security Council (Resolution No. 1373 dated 28 September 2001) which emphasized the need to curb terrorist activities by freezing and forfeiture of funds and financial assets employed to further terrorist activities. It will also be interesting to notice [...] the United Nations International Convention for the Suppression of the Financing of Terrorism but at the same time it is not necessary to go into those details in the present context. The scheme of the provisions indicates that the principles of natural justice are duly observed and they do not confer any arbitrary power, and forfeiture can only be made by an order of the Court against which an appeal is also provided to the High Court and the rights of [the] bona fide transferee are not affected. Therefore, for the present, it is not necessary to pronounce on the constitutional validity of these provisions and we proceed on the basis that they are valid.

The Court upheld the constitutional validity of the POTA and the provisions which were specifically challenged.

11 The constitutional validity of several provisions of the POTA were challenged which inter alia, included the powers of the investigating officers, the word 'abet' in the context of a terrorist act, the issue of knowledge or mens rea. 


\section{Issues relating to Environment Protection and Right to Development - Applica- tion of Precautionary Principle in the context of Large Dams - Sustainable Development - Disaster Management}

\section{N.D. JAYAL AND ANOTHER v. UNION OF INDIA AND OTHERS}

\section{Supreme Court of India, 9 September 2003 AIR 2004 Supreme Court 867}

Facts

The petitioners were seeking the intervention of the court concerning the safety ${ }^{12}$ and environmental aspects of the Tehri Dam, ${ }^{13}$ a dam being built in a seismic-prone zone in the Himalayan region. The proposal to build a dam was conceived in the 1960s; several Committees of Experts on various technical issues investigated environmental, seismic and rehabilitation issues. At one stage, the Government of India had stayed the operation of the dam on environmental considerations. Finally, while granting a conditional clearance to the project in 1990, the Government had sought: (a) environmental safeguard measures planned and implemented pari passu with progress of work on the project; (b) the detailed surveys and studies to be carried out according to the proposed schedule and details made available to the Department for assessment; (c) the catchment area treatment programme and the rehabilitation plans be so drawn up as to be completed ahead of the filling of the reservoir, and (d) the Department should be kept informed of progress on various works periodically. ${ }^{14}$

\section{The Judgment}

The Court, while refusing to re-open discussion on the safety aspects of the dam, dealt with matters pertaining to the preservation of the ecology and development. The Court referring to its earlier cases ${ }^{15}$ observed:

\footnotetext{
12 Petitioners had sought to conduct a Three-Dimensional (3D) Non-Linear Test to evaluate the earthquake susceptibility of the dam against the Maximum Credible Earthquake. However, the Court refused to go into this question as the safety aspects had been considered in an earlier case by the Supreme Court in 1992, namely, Tehri Bandh Virodhi Sangarsh Samiti v. State of Uttar Pradesh. 13 The Tehri Dam, located in the Himalayan region, was constructed at the confluence of the Bhagirathi and Bhailangana rivers in the neighbourhood of the Garhwal town in the State of Uttaranchal, resulting in the relocation of an entire town.

14 These four conditions had been laid down by the Supreme Court in Narmada Bachao Andolan v. Union of India, AIR 2000 SC 3751. Specifically on this project, the following conditions related to the completion or compilation of data and an action plan relating to: (a) catchment area treatment; (b) command area development; (c) flora and fauna; (d) water quality maintenance; (e) Bhagirathi Basin Management Authority; (f) Disaster Management, and (g) rehabilitation.

15 Vellore Citizens Welfare Forum v. Union of India, AIR 1996 SC 2715 and M.C. Mehta v. Union of India, AIR 2002 SC 1696.
} 
[T] he balance between environmental protection and developmental activities could only be maintained by strictly following the principle of 'sustainable development'. This is a development strategy that caters to the needs of the present without negotiating the ability of upcoming generations to satisfy their needs. The strict observance of sustainable development will put us on a path that ensures development while protecting the environment, a path that works for all peoples and for all generations. It is a guarantee to the present and a [bequest] to the future that all environmental related developmental activities should benefit more people while maintaining the environmental balance. This could be ensured only by the strict adherence to sustainable development without which life of coming generations will be in jeopardy.

The Court, while recognizing the right to a clean environment as a fundamental right under Article 21 of the Indian Constitution, addressed the question of placing the right to development within the same legal reasoning. Thus, the Court observed:

The right to development cannot be treated as a mere right to economic betterment or cannot be limited to a misnomer for simple construction activities. The right to development encompasses much more than economic well-being and includes within its definition the guarantee of fundamental human rights. The 'development' is not related only to the growth of GNP. In the classic work 'Development As Freedom', the Nobel prize winner Amartya Sen pointed out that 'the issue of development cannot be separated from the conceptual framework of human rights'. This idea is also part of the UN Declaration on the Right to Development. The right to development includes the whole spectrum of civil, cultural, economic, political and social process[es], for the improvement of peoples' wellbeing and realization of their full potential. It is an integral part of human rights. Of course, construction of a dam or a mega project is definitely an attempt to achieve the goal of wholesome development. Such works could very well be treated as an integral component for development.

The Court examined each of the components of the conditional clearance such as (a) catchment area treatment; (b) command area development; (c) flora and fauna; (d) water quality maintenance; (e) Bhagirathi Basin Management Authority; (f) Disaster Management, and (g) rehabilitation. After examining these aspects, the majority decision of the Court pointed out that the petitioners had disputed "the extent of compliance only and not that there is no compliance at all". The majority decision found that there was compliance, although with certain lapses. According to the Court, these lapses in compliance could be prevented by the setting up of monitoring agencies. Dharmadhikari, J., while dissenting with these conclusions, particularly on the safety aspects of the dam, observed:

On the safety aspect of the Dam, particularly when the location of the Dam is in a highly earthquake-prone zone in the valleys of Himalayas, all additional safeguards are required to be undertaken on the 'precautionary principle' as contained in the Rio Declaration on Environment and Development taken in the United Nations Conference held in January 1992 to which India is a party. The precautionary principle in the Rio Declaration reads: 
"In order to protect the environment, the precautionary approach shall be widely applied by States accordingly to their capabilities. Where there are threats of a series of reversible damage, lack of full scientific certainty shall not be used as a reason for postponing cost effective measures to prevent environment degradation."

\section{Dharmadhikari, J. further observed:}

The precautionary principle accepted by India being a party and signatory to international agreement and understandings in the field of environment has become part of domestic law, i.e., the Environmental Protection Act. The Governmental authorities in India cannot be permitted to set up a plea of scientific uncertainty of [the] 3-D Non-Linear Analysis of the Dam. On the safety aspect, the pleas like res judicata based on [an] earlier decision of this Court cannot be allowed to be raised when further developments and events in the course of the Project require further precautions to be taken before filling the Dam to the optimum capacity. It is not the case of the respondents that [the] 3-D Non-Linear Analysis of the Dam cannot be undertaken with the assistance of foreign Experts on the subject. To take care of all eventualities of damage to [the] Dam by earthquake [the] 3-D Non-Linear Analysis of the Dam suggested by four Experts as a matter of abundant caution must be undertaken. It is only after [the] 3-D Non-Linear Analysis of the Dam is completed and the opinion of the Experts on the safety aspect is again sought that further impoundment of the Dam should be allowed. In M.C. Mehta v. Union of India (Trapezium Matter) (1997 (2) SCC 353), this Court has applied the 'Polluter pays principle' and the 'Precautionary principle' of international law as the law of the land of this country, India being party to the United Nations Conference and signatory to International Declarations and Agreements.

While dealing with issues of protection of environment, natural resources and rehabilitation, Dharmadhikari, J. concluded:

The Rio Declaration on Environment and Development in the United Nations Conference held in June 1992 to which India was a party and signatory and on which the Environment Protection Act, its Rules and Policies are modelled obligates the Authorities of India by the norms fixed in International and Domestic Law that the environmental and natural resources of people under operation, domination and occupation shall be protected. 
Scope and Application of Bilateral Double Taxation Avoidance Convention between India and Mauritius - In the event of Conflict Provisions of Bilateral Tax Treaty to prevail over Income-tax Act (section 90) - Treaty-making power of the State

\title{
UNION OF INDIA v. AZADI BACHAO ANDOLAN
}

\author{
Supreme Court of India, 10 October 2003 \\ AIR 2004 Supreme Court 1107
}

Facts

The Petitioners challenged two Circulars ${ }^{16}$ issued by the Government of India pursuant to which certain instructions were issued to income-tax authorities concerning assessment of income-tax cases pertaining to Foreign Institutional Investors (FIIs) based in Mauritius, involving the interpretation of the Indo-Mauritius Double Taxation Avoidance Convention, 1983 (hereinafter 'DTAC'). These FIIs, relying on these Circulars, invested large amounts of capital in shares in Indian companies with the expectation of making profits through the sale of such shares without being subjected to tax in India. ${ }^{17}$ In 2000, Indian income-tax authorities issued Show Cause notices to some FIIs functioning in India yet registered in Mauritius, calling upon them to show cause as to why they should not be taxed for profits and for dividends accrued to them in India. These companies were registered or incorporated in Mauritius and their main purpose was to invest in the Indian share market without being liable to be taxed. The Petitioners, inter alia, argued that these companies were controlled and managed from countries other than India or Mauritius and as such they were not "residents" 18 of Mauritius so as to derive the benefits of the DTAC. ${ }^{19}$ The

16 Circular No. 682 dated 30 March 1994 clarifying that the capital gains of any resident of Mauritius acquired by the alienation of shares of an Indian company shall be taxable only in Mauritius according to Mauritius taxation laws and will not be liable to tax in India. The other Circular was No. 789 dated 13 April 2000 further clarifying the legal position of the taxability of capital gains and dividends in India.

17 Section 90 of the Indian Income-Tax Act dealt with the relationship between DTAC and the Income Tax Act. In other words, it, inter alia, covered the Agreements concluded by the Government of India with the Government of any country outside India (a) for the granting of relief in respect of income tax payable in the other country; (b) for the avoidance of double taxation of income; (c) for exchange of information for prevention of the evasion or avoidance of income tax; (d) for recovery of income tax as per the laws of either country; and to make necessary provisions as may be necessary for implementing the agreement. The other important feature of section 90 was that DATC provisions prevailed over the provisions of the Income Tax Act for granting relief of tax or as the case may be avoidance of double taxation to the extent they were more beneficial to the assessee.

18 According to Article 4 of the DTAC, a "resident" of one State should be any person who, under the laws of that State, was liable to taxation therein by reason of his domicile, residence, place of management or any other criterion of a similar nature. 
Court had to consider the scope and application of Section 90 of the Indian IncomeTax Act in relation to the DTAC with Mauritius.

\section{The Judgment}

The Court dealt with the issue of exercise of fiscal jurisdiction by States and the complexities involved in moderating such a jurisdiction through bilateral tax treaties. The Court, in fact, outlined the rationale behind concluding tax treaties. The Court stated:

Every country seeks to tax the income generated within its territory on the basis of one or more connecting factors such as the location of the source, residence of the taxable entity, maintenance of a permanent establishment and so on. A country might choose to emphasise one or the other of the aforesaid factors for exercising fiscal jurisdiction to tax the entity. Depending on which of the factors is considered to be the connecting factor in different countries, the same income of the same entity might become liable to taxation in different countries. This would give rise to harsh consequences and impair economic development. In order to avoid such an anomalous and incongruous situation, the Governments of different countries enter into bilateral treaties, conventions or agreements for granting relief against double taxation. Such treaties, conventions or agreements are called double taxation avoidance treaties, conventions or agreements.

The Court first dealt with the Constitutional sources of executive authority in concluding a treaty. While noting that the power of entering into a treaty is an inherent part of the sovereign power of the State, in the Indian context, the Court stated:

Our Constitution makes no provision making legislation a condition for entry into an international treaty in time either of war or peace. The executive power of the Union is vested in the President and is exercisable in accordance with the Constitution. The Executive is qua the State competent to represent the State in all matters international and may by agreement, convention or treaty incur obligations which in international law are binding upon the State. But the obligations arising under the agreement or treaties

\footnotetext{
19 The Delhi High Court had concurred with the arguments of the petitioners and accordingly had quashed the Circulars. Briefly, the findings of the High Court were, inter alia, (a) certificate of residence issued by authorities of Mauritius as insufficient evidence as regards the status of the resident and beneficial ownership; (b) the income-tax officer, in his quasi-judicial function, be entitled to lift the corporate veil in order to see whether the company is actually a resident of Mauritius or not and whether the company was paying income tax in Mauritius or not; (c) conclusiveness of a certificate of residence issued by the Mauritius Tax Authorities contemplated neither under the DTAC nor under the Indian Income Tax Act; (d) "Treaty-shopping" by which the resident of a third country took advantage of the provisions of the Agreement was illegal and thus necessarily forbidden; (e) avoidance of double taxation had been a term of art and meant accordingly as that a person had to pay tax in at least one country; avoidance of double taxation would not mean that a person did not have to pay tax in any country whatsoever.
} 
are not by their own force binding upon Indian nationals. The power to legislate in respect of treaties lies with the Parliament under entries 10 and 14 of List I of the Seventh Schedule. But making of law under that authority is necessary when the treaty or agreement operates to restrict the rights of citizens or others or modifies the law of the State. If the rights of the citizens of others which are justificable are not affected, no legislative measure is needed to give effect to the agreement or treaty. ${ }^{20}$

On the issue of implementation of tax treaties and section 90 of the Indian Income-Tax Act, the Court, while providing justification for such a provision in Income-Tax law, noted:

\begin{abstract}
When it comes to fiscal treaties dealing with double taxation avoidance, different countries have varying procedures. In the United States, such a treaty becomes a part of municipal law upon ratification by the Senate. In the United Kingdom, such a treaty would have to be endorsed by an order made by the Queen in Council. Since in India such a treaty would have to be translated into an Act of Parliament, a procedure which would be timeconsuming and cumbersome, a special procedure was evolved by enacting Section 90 of the Act.
\end{abstract}

Considering the legislative history of Section 90, the Court further noted that "Since tax treaties are intended to grant tax relief and not put residents of a contracting country at a disadvantage vis-à-vis other taxpayers, Section 90 of the Income-tax Act has been amended to clarify that any beneficial provision in the law will not be denied to a resident of a contracting country merely because the corresponding provision in the tax treaty is less beneficial". Surveying the case laws of various High Courts within India, the Court concluded that the judicial consensus in India had been that Section 90 was specifically intended to enable and empower the Central Government to issue a notification for the implementation of the terms of a double taxation avoidance agreement. When that happens, the Court further concluded, the provisions of such an agreement, with respect to cases where they apply, would operate even if inconsistent with the provisions of the Income-tax Act. The Court, while referring to the contention of the respondents that according to Article 265 of the Constitution no tax could be levied or collected except by authority of law, pointed out that Section 90 was brought onto the Statute book precisely to enable the executive to negotiate a DTAC and quickly implement it. ${ }^{21}$

\footnotetext{
${ }^{20}$ See in this connection Maganbhai Ishwarbhai Patel and Others v. Union of India and another (1970) 3. SCC 400 (as cited by the Court)

${ }^{21}$ While on this issue, the Court considered in detail the whole matter of delegated power of legislation and as to why a delegatee of legislative power in all cases should have no power to grant exemption. The Court also dealt with the issue of enabling powers of the tax authorities to issue notifications, circulars, etc. under Section 119.
} 
Implementation of Certain Provisions of The International Convention on Standards of Training, Certification and Watchkeeping for Seafarers, 1978 (STCW 78) - Interpretation of Amendments to the Merchant Shipping Act, 1958 specifically relating to the obtaining of Certificate of Service in consonance with the STCW 78

\section{NARESH KUMAR v. UNION OF INDIA}

\section{Supreme Court of India, 5 April 2004 \\ AIR 2004 Supreme Court 2026}

Facts

The issue involved the recognition of Certificates of Service (CoS) and Certificates of Competence ( $\mathrm{CoC}$ ) obtained by the officers of the Indian Navy while they were in service, without examination, for the purposes of the Merchant Navy according to the requirements of the Merchant Shipping Act, 1958. Section 80 of the Merchant Shipping Act, 1958 which provided this recognition was repealed in 1986 to give effect to the standards of Convention on Standards of Training, Certification and Watchkeeping for Seafarers (STCW) 1978. This Certificate was a requirement under the STCW 1978. The STCW 1978 was amended in 1995 to become known as STCW 1995. The STCW 1995 provided that existing holders of the certificate should complete approved training assessment and obtain a fresh Certificate of Competence. Pursuant to this, the Government of India issued necessary notifications implementing the requirements of STCW 1995. The short question that arose before the Court concerned whether the Certificate of Service issued under Section 80 of the Merchant Shipping Act (now repealed) could continue to be treated as a Certificate under the Convention after the 1978 Convention, as amended by STCW 1995 which subsequently came into force.

The Judgment

The Court, while looking at the setting of the STCW 1978, noted the current status of the Convention vis-à-vis India. It stated:

The International Convention on Standards of Training, Certification and Watchkeeping for Seafarers 1978 (STCW 78) came into force globally. India was one of the signatories to the Convention and ratified the Convention on 16 February, 1986. The object of the Convention is to have uniform standards of training and certification. Thus, Article VI of the 1978 Convention enjoins that Certificates be issued for masters, officers or ratings. It provides that these shall be issued to those candidates who meet the requirements for service, age, medical fitness, training, qualification and examinations in accordance with the appropriate provisions. The 1978 Convention was amended in 1995 and is known as STCW 1995. This 1995 Convention extensively amended the 1978 Convention, but Article I to XVII of the 1978 Convention remained unamended. Consequently, the 
Merchant Shipping (STCW) Rules, 1998 were also framed. Rule 11, inter alia, requires that existing $\mathrm{CoS}$ holders who intend to become holders of the $\mathrm{CoC}$ shall be required to complete approved training assessment. Similarly, Rule 15 requires that every Master on a seagoing of 500 gross tonnage or more shall hold an appropriate Certificate of Competency in Form 3.

The Court did not agree with the contention of the Petitioners that Section 5 of the amended Merchant Navy Act, 1958 saved some of the effects of the repealed Section 80 (which recognized the Navy officers' Certificate of Service) of the Merchant Shipping Act, 1958. The Court, examining the status of Section 80, stated,

No doubt Section 80 of the Act was holding the field before it was amended but it has been eclipsed with the emergence of the 1978 Convention as amended by the 1995 Convention. With the emergence of the 1995 Convention there is no provision for indefinite continuance of $\mathrm{CoS}$ in respect of the officers of the Merchant Ships. As already noticed, the petitioners are now serving in [the] Merchant Navy. India, being a signatory to the 1995 Convention, has to ensure uniform standards, as prescribed by the Convention.

On an Undertaking by the Director-General of Shipping, the Government of India, on working out the procedural details of the implementation mechanism consistent with the STCW, the Court disposed of the petition.

\section{Definition of 'Terrorism'- Relationship between Terrorist Activity and Crime - Surveying of the Attempts made by the Untied Nations and Other Bodies to Define 'terrorism'}

\section{MADAN SINGH v. STATE OF BIHAR}

\section{Supreme Court of India, 2 April 2004} AIR 2004 Supreme Court 3317

\section{Facts}

Twenty persons faced trial for the alleged commission of various offences punishable under the Indian Penal Code, Terrorist and Disruptive Activities (Prevention) Act, 1987 (TADA) and the Arms Act. One of the main contentions of the Appellants was that there was no evidence to show that the accused persons were terrorists or extremists or that the activities or actions alleged were encompassed by the provisions of the TADA Act to be described as terrorist acts.

\section{The Judgment}

The Court, after dealing with the factual scenario in the case, considered the definitional issues concerning 'terrorism' and 'terrorist activity'. The Court, inter alia, noted that "A 'terrorist' activity does not merely arise by causing disturbance 
of law and order or of public order. The fallout of the intended activity is to be one that it travels beyond the capacity of the ordinary law enforcement agencies to tackle it under the ordinary penal law. It is in essence a deliberate and systematic use of coercive intimidation". Further, the Court, while distinguishing between criminal activity and terrorism, stated:

Finding a definition of "terrorism" has haunted countries for decades. A first attempt to arrive at an internationally acceptable definition was made under the League of Nations, but the one which the convention drafted in 1937 never came into existence. The UN member States still have not agreed upon a definition apparently on account of what at times [is] reveal[ed] to be State sponsored terrorism, both at national and international levels. Terminology consensus would, however, be necessary for a single comprehensive convention on terrorism which some countries favour in place of the present 12 piecemeal conventions and protocols. The lack of agreement on a definition of terrorism has been a major obstacle to meaningful international counter-measures. Cynics have often commented at national and international levels that one State's "terrorist" is another State's "freedom fighter" and that too with the blessings of those in power. Crime became a highly politicised affair; greed compounded by corruption and violence enabled unscrupulousness, and hypocrisy reigns supreme supported by duplicity and deceitful behaviour in public life to amass and usurp public power to perpetuate personal aggrandizement, pretending to be for the common good. If terrorism is defined strictly in terms of attacks on non-military installations and soldiers residences could not be included in the statistics. In order to cut through the Gordian definitional knot, terrorism expert A. Schmid suggested in 1992 in a report for the then UN Crime Branch that it might be a good idea to take the existing consensus on what constitutes a "war crime" as a point of departure. If the core of war crimes - deliberate attacks on civilians, hostage-taking and the killing of prisoners - is extended to peacetime, we could simply define acts of terrorism veritably as "peacetime equivalents of war crimes".

The Court, inter alia, while referring to various definitions of 'terrorism', specifically to United Nations General Assembly Resolution 51/210 on Measures to Eliminate International Terrorism, concluded:

Terrorism is one of the manifestations of increased lawlessness and the cult of violence. Violence and crime constitute a threat to an established order and are a revolt against a civilized and orderly society. "Terrorism", though, has not been separately defined under TADA, but there is sufficient indication in Section 3 itself to identify what it is by an all inclusive and comprehensive phraseology adopted in engrafting the said provision, which serves the double purpose as a definition and punishing provision; nor is it possible to give a precise definition of "terrorism" or lay down what constitutes "terrorism". It may be possible to describe it as use of violence when its most important result is not merely the physical and mental damage of the victim but the prolonged psychological effect it produces or has the potential of producing on the society as a whole. There may be death, injury, or destruction of property or even deprivation of individual liberty in the process, but the extent and reach of the intended terrorist activity travels beyond the 
effect of an ordinary crime capable of being punished under the ordinary penal law of the land and its main objective is to overawe the Government or disturb the harmony of the society or "terrorise" people and the society and not only those directly assaulted, with a view to disturb the even tempo, peace and tranquillity of the society and create a sense of fear and insecurity.

The Court concluded that the appeals were sans merit and deserved dismissal.

Scope of Application of Internet Domain Names and Passing off Action in Trademark Law - International Regime on Internet Domain Names - Internet Corporation for Assigned Names and Numbers (ICANN) and World Intellectual Property Organization (WIPO)

\section{SATYAM INFOWAY LTD v. SIFYNET SOLUTIONS PVT. LTD}

Supreme Court of India, 6 May 2004

AIR 2004 Supreme Court 3541

Facts

The principal question, as noted by the Court, was whether Internet domain names were subject to the legal norms applicable to other Intellectual Property Rights such as trademarks. The Appellant, incorporated in 1995, had registered several domain names with the word 'sify' in June 1999 with the Internet Corporation for Assigned Names and Numbers (ICANN) and the WIPO. According to the Appellant, the word 'sify' was invented by using elements of its corporate name Satyam Infoway, accordingly claiming a wide reputation and goodwill. The Respondent, on the other hand, used the word 'siffynet' for his Internet marketing business in 2001. The Respondent, the Court noted, claimed itself to have obtained registration of this name with ICANN in 2001 .

The Appellant filed a suit in the civil court on the basis that the Respondent was passing off its business and services by using the Appellant's business name and domain name. The civil court, upon an application by the Appellant, granted a temporary injunction on the grounds that the Appellant was the prior user of the trade name 'sify' and that confusion would be caused in the mind of the general public by such deceptive similarity. The balance of convenience, the civil court found, was in favour of the Appellant. The Respondent preferred an appeal to the High Court and the same was allowed by the High Court after reconsidering the issue of 'balance of convenience'. The High Court also referred to the business carried out by the Respondent and noted that it was different from the one carried out by the Appellant; accordingly there was no question of customers being misled or confused. The impugned order by the High Court, as noted by the Supreme Court, primarily proceeded on the basis that the principles relating to passing off actions in connection with trademarks are applicable to domain names. It was contended that a domain 
name could not be confused with "property names" such as Trademarks. Domain names, it was argued, constituted merely an address on the Internet. It was also submitted that registration of a domain name with ICANN did not confer any intellectual property right, that it was a contract with a registration authority allowing communication to reach the owner's computer via Internet links channelled through the registration authority's server and that it was akin to the registration of company name which was a unique identification of a company, but of itself conferred no intellectual property rights.

\section{The Judgment}

The Court, after examining the definitional aspects of 'trade mark', 'mark', 'goods' and 'services', sought to place the aspects of 'domain name' as a 'property right'. The Court noted that:

With the increase of commercial activity on the Internet, a domain name is also used as a business identifier. Therefore, the domain name not only serves as an address for Internet communication but also identifies the specific Internet site. In the commercial field, such domain name owner provides information/services which are associated with such domain name ... Consequently, a domain name as an address must, of necessity, be peculiar and unique and where a domain name is used in connection with a business, the value of maintaining an exclusive identity becomes critical.

The Court further examined the relationship between passing off, i.e., to pass off to the public the goods and services of others as that of his own, and trademark law. While passing off claims were made in a given case, the important question, according to Court, was: Who invented the mark first? The prior user, the Court further noted, would succeed depending upon the fact that (a) it would not be essential to prove 'long user' to establish reputation in a passing off action; and (b) it would, rather, be important to prove the volume of sales and extent of advertisement. The other element that must be established in a passing off action would be the factor of 'misrepresentation to the public'. The Court, while noting that the 'intention' to misrepresent was important, stated that the relevant factor which needed to be established was the likelihood of confusion in the minds of the public (the term 'public' to mean actual or potential customers or users).

On the question of a passing off action resulting in loss or the likelihood of it, the Court stated:

The use of the same or similar domain name may lead to a diversion of users which could result from such users['] mistakenly accessing one domain name instead of another. This may occur in e-commerce with its rapid progress and instant (and theoretically limitless) accessibility to users and potential customers and particularly so in areas of specific overlap. Ordinary consumers/users seeking to locate the functions available under one domain name may be confused if they accidentally arrived at a different but similar web 
site which offers no such services. Such users could well conclude that the first domain name owner had misrepresented its goods or services through its promotional activities and the first domain owner should thereby lose their customer. It is apparent therefore that a domain name may have all the characteristics of a trademark and could found an action for passing off.

The Court further noted that there was an operational distinction between a trademark and a domain name at the international level. The Court stated:

A trademark is protected by the laws of a country where such trademark may be registered. Consequently, a trade mark may have multiple registrations in many countries throughout the world. On the other hand, since the Internet allows for access without any geographical limitation, a domain name is potentially accessible irrespective of the geographical location of the consumers. The outcome of this potential for universal connectivity is not only that a domain name would require world wide exclusivity but also that national laws might be inadequate to effectively protect a domain name. The lacuna necessitated international regulation of the domain name system (DNS). This international regulation was effected through WIPO and ICANN. India is one of the 171 States of the world which are members of WIPO. WIPO was established as a vehicle for promoting the protection, dissemination and use of intellectual property throughout the world. Services provided by WIPO to its member States include the provision of a forum for the development and implementation of intellectual property policies internationally through treaties and other policy instruments.

Referring to Uniform Domain Name Disputes Resolution Policy (UDNDR Policy) by ICANN (established in October 1999), the Court noted that this dispute resolution mechanism did not have same consequences under the Indian Trade Marks Act, 1999, although it at least evidenced the recognized user of the mark. The Court further noted that the UDNDR policy was instructive as to the kind of rights which a domain name owner might have upon registration with ICANN accredited Registrars. While outlining the main contours of ICANN dispute resolution mechanism, the Court noted:

As far as India is concerned, there is no legislation which explicitly refers to dispute resolution in connection with domain names. But although the operation of the Trade Marks Act, 1999 itself is not extra-territorial and may not allow for adequate protection of domain names, this does not mean that names are not to be legally protected to the extent possible under the laws relating to passing off.

The Court, in the final analysis, coming to the merits of the case and basing its reasoning with regard to the passing off action on the goodwill, commercial loss and similarity (both visual and phonetic) that a trader had in his name as being similar to in an action for infringement of a trade mark, decided the matter in favour of the Appellant. 


\title{
Scope and application Environment Protection Act, 1986 - Stockholm Declara- tion of 1972 and the Development of Indian Laws on Environment - Balancing of Environment Protection and the Socio-economic Needs
}

\author{
ESSAR OIL LTD. v. HALAR UTKARSH SAMITI AND OTHERS
}

\section{Supreme Court of India, 19 January 2004 AIR 2004 Supreme Court 1834}

Facts

The issue related to the laying down of pipelines to pump crude oil from a single buoy mooring in the Gulf across a portion of the Jamnagar Marine National Park and Marine Sanctuary located along the lower lip of the Gulf of Katchch in the State of Gujarat. The Court had to decide the legality, as challenged through several public interest petitions, of the laying of the pipelines in accordance with the provisions of the Wildlife Protection Act, 1972, the Forest (Conservation) Act, 1980 and the Environment (Protection) Act, 1986. While interpreting the provisions of these enactments, the Court, in its obiter, referred to the effect of the Stockholm Declaration of 1972 and other related international environmental legal provisions in shaping the Indian law on the subject, in particular Section 29 of the Wildlife (Protection) Act, 1972 which inter alia, provided that:

\begin{abstract}
No person shall destroy, exploit or remove any wildlife from a sanctuary or destroy or damage the habitat of any wild animal or deprive any wild animal of its habitat within such sanctuary except under and in accordance with permit granted by the Chief Wildlife Warden and no such permit shall be granted unless the State Government, being satisfied that such destruction, exploitation or removal of wildlife from the sanctuary is necessary for the improvement and better management of wildlife therein, authorizes the issue of such permit
\end{abstract}

The Judgment

The Court, while interpreting Section 29 of the Wildlife (Protection) Act, 1972, noted that this interpretation must be done keeping in mind the Stockholm Declaration of 1972. The Court observed:

Indeed, in the wake of the Stockholm Declaration in 1972, as far as this country is concerned, provisions to protect the environment were incorporated in the Constitution by an amendment in 1976. Article 48A of the Constitution now provides that the "State shall endeavour to protect and improve the environment and to safeguard the forests and wildlife of the country". It is also one of the fundamental duties of every citizen of the country under Art. 51A (g) "to protect and improve the natural environment including forests, lakes, rivers and wildlife and to have compassion for living creatures". 
The Court outlined various Principles of the Stockholm Declaration to sustain humanity and its environment. While emphasizing the need to balance economic and social needs, on the one hand, with environment considerations, on the other, the Court stated:

Indeed, the very existence of humanity and the rapid increase in the population together with consequential demands to sustain the population has resulted in the concreting of open lands, cutting down of forests, the filling up of lakes and pollution of water resources and the very air which we breathe. However, there need not necessarily be a deadlock between development on the one hand and the environment on the other. The objective of all laws on environment should be to create harmony between the two since neither one can be sacrificed at the altar of the other.

The Court interpreted Section 29 of the Wildlife (Protection) Act, 1972 and sought to answer the question as to whether it could be stated that the laying of pipelines through a sanctuary necessarily results in the destruction of wildlife. The Court, considering the legal position in England and other countries, noted that it would ultimately be a question of fact to be determined by experts in each case and accordingly asked the State Government to obtain an environmental impact report from expert bodies. It also sought an environmental management plan. The Court also laid emphasis on transparency and the sharing of information with those who were affected by this decision.

Interpretation of Section 45 and Section 8 of the Indian Arbitration and Conciliation Act, 1996 - Extent of Judicial Intervention to refer the matter to Arbitration - Legality of Arbitration Agreement - Whether Courts should take a prima facie view while deciding the Legality - Application and Interpretation of UNCITRAL Model Law on International Commercial Arbitration

SHIN-ETSU CHEMICAL CO. LTD. v. M/S AKSH OPTIFIBRE LTD.

\section{Supreme Court of India, 12 August 2005}

AIR 2005 Supreme Court 3767

Facts

The parties concluded an agreement in November 2000 with an arbitration clause which, inter alia, provided that the governing law would be Japanese Law and the arbitration would be held in Tokyo, Japan in accordance with the Rules of Conciliation and Arbitration of the International Chamber of Commerce. It was also agreed that the award of arbitration should be final and binding on both of the parties. The Appellant terminated the agreement in December 2002. The Respondent, thereafter, instituted a suit claiming a decree of declaration and injunction against the Appellant for cancellation of the agreement and a declaration that the long-term sale and purchase agreement of November 2000 including the arbitration clause were un- 
conscionable, unfair and unreasonable and against the public policy; the same was entered into under undue influence and was, therefore, void ab initio, inoperative, incapable of performance and could not be given effect. The Appellant, invoking Section $8^{22}$ of the Indian Arbitration and Conciliation Act, 1996 pleaded before the court that the Respondent should be directed to submit before the arbitration proceedings in Tokyo. The Trial Court concurred with the Appellant and remitted the parties to arbitration. The High Court, on an appeal, took a different view and pointed out that the matter should have been examined under Section $45^{23}$ as well, and remitted the matter back to the trial court for reconsideration. The legal question before the Court was with regard to the nature of adjudication contemplated by Section 45 when the objection about the agreement being "null and void, inoperative or incapable of being performed", that is, whether the judicial authority while exercising power under Section 45 should decide the objection on a prima facie view of the matter and render a prima facie finding or a final finding on merits on affording parties such opportunity as the justice of the case may demand having regard to the facts of the case.

\title{
The Judgment
}

According to the Court, the entire issue arose on account of the nature of legislative consolidation under the Indian law on the subject which now dealt, in a single text, with domestic arbitration, international commercial arbitration, and enforcement of foreign arbitral awards. The Court noted that

\begin{abstract}
Before enactment of the Act there were separate statutes governing international arbitration and domestic arbitration, namely, the Arbitration (Protocol and Convention) Act, 1937 (6 of 1937), The Arbitration Act, 1940 (10 of 1940) and The Foreign Awards (Recognition and Enforcement) Act, 1961 (45 of 1961). These statutes have been repealed as provided in Section 85 of the Act.
\end{abstract}

The Court further noted that "The 1996 Act was enacted considering the international scenario as is evident from its Preamble". Quoting the Preamble of the Indian Arbitration and Conciliation Act, 1996 which, inter alia, referred to UNCITRAL Model Law on International Commercial Arbitration, 1985, UNCITRAL Conciliation Rules,

\footnotetext{
${ }^{22}$ Section 8 is essentially a provision to desist parties from going to the court on any pretext. It read, inter alia: "A judicial authority before which an action is brought in a matter which is the subject of an arbitration agreement shall, if a party so applies not later than when submitting his first statement on the substance of the dispute, refer the parties to arbitration".

${ }^{23}$ Section 45 fell within the ambit of 'enforcement of arbitral awards'; the 'agreement' referred to in this section is in relation to enforcement. Section 45 reads: "Notwithstanding anything contained in Part I or in the Code of Civil Procedure, 1908 (5 of 1908), a judicial authority, when seized of an action in a matter in respect of which the parties have made an agreement referred to in Section 44 , shall, at the request of one of the parties or any person claiming through or under him, refer the parties to arbitration, unless it finds that the said agreement is null and void, inoperative or incapable of being performed".
} 
1980, and the "desirability of uniformity of the law of arbitral procedures and the specific needs of international commercial arbitration practice", the Court noted the entire enforcement scheme in the context of present case. It stated:

The enforcement of foreign awards has been dealt with in Part II of the Act which has two Chapters, Chapter I dealing with New York Convention Awards and Chapter II dealing with Geneva Convention Awards. In this matter we are concerned with Chapter I which comprises of Sections 44 to 52. Section 44 defines foreign award. It is not in dispute that the present case falls under the ambit of Section 44 . Section 45 has already been extracted above. Conditions for enforcement of foreign awards are stipulated in Section 48 under which enforcement may be refused at the request of the party against whom it is invoked only if that party furnishes to the court proof as postulated in Clauses (a) and (e). In addition, the enforcement of the award may also be refused on the grounds stipulated in Section 48 (2) of the Act. Section 49 provides that where the court is satisfied that the foreign award is enforceable under Chapter I, the award shall be deemed to be a decree of the court. Section 50 provides as to against which orders an appeal shall lie.

The Court, noting that the judicial interference had been limited to a narrower circumference than under the old arbitration laws, continued with the examination of standard of review in relation to Section 45 - a prima facie finding or a final finding? The Court noted the similarity of language between Section 45 and other international conventions on the subject, such as the Geneva Protocol on Arbitration Clauses in Commercial Matters (1923) (Art. IV, Para. 1), the New York Convention (Art. II, Para. 3) as well as UNCITRAL Model Law (Art. VIII). The Court, while referring to cases in other national jurisdictions, further noted that:

Apart from the fact that the Arbitration and Conciliation Act, 1996 is not a complete adaptation of the UNCITRAL Model Law, the scheme/provisions of the Hong Kong Arbitration Ordinance are different from the Arbitration and Conciliation Act, 1996. Therefore, it may not be appropriate to follow the decisions interpreting the provisions of the UNCITRAL Model Law or the Hong Kong Arbitration Ordinance.

The Court confirmed the decision of the High Court in remanding the application under Section 45 of the Arbitration and Conciliation Act, 1996 for a fresh decision by the trial court. 
Influx of Illegal Migrants in large numbers - Does the Influx of a Large Population amount to 'aggression' under International Law? - Definition of 'Aggression' and its Historical Overview in the Indian Context - Treatment of Aliens under International Law

\section{SARBANANDA SONOWAL v. UNION OF INDIA AND ANOTHER}

Supreme Court of India, 12 July 2005

AIR 2005 Supreme Court 2920

Facts

The Writ Petition filed before the Supreme Court by way of public interest litigation was for declaring certain provisions of the Illegal Migrants (Determination by Tribunals) Act, (Act No. 39 of 1983), ${ }^{24} 1983$ (hereinafter, the 'IMDT Act') as ultra vires the Constitution of India, null and void; and the consequent declaration that the Foreigners Act, 1946 and the Rules made thereunder should apply to the State of Assam.

The Judgment

The Court considered various status reports on the influx of migrants into the State of Assam and also the status reports on the implementation of the IMDT Act. The consequences of such influx were also considered by the Court. The Court, taking into account the entire issue in its historical context, considered the implementation of various accords concluded between, on one side, the Government of India and the Government of Assam, and on the other the agitating/affected parties. The legal effects of such accords and their implications on the demography of Assam were also considered by the Court. The Court also considered the plea that the foremost duty of the Central Government was to defend the borders of the country, prevent any trespass and make the life of the citizens safe and secure. ${ }^{25}$ Referring to various international legal scholars, the Charter of the United Nations, the Work of the International Law Commission, and the UN Special Committee on Aggression, the Court noted that "a consensus was arrived at and an agreed definition was approved

${ }^{24}$ The IMDT Act was passed by the Indian Parliament in 1983. It was made applicable only to the State of Assam. The scope of this enactment was to determine whether a person who entered India after 25 March 1971, without valid passport or travel documents, was or was not an illegal migrant. The Foreigners Act of 1946 which actually governed such cases of the entry of illegal migrants was not made applicable to the State of Assam.

${ }^{25}$ The Court is referring to Article 355 of the Constitution of India which, inter alia, states: "[The] duty of the Union to protect States against external aggression and internal disturbance and to ensure that the Government of every State is carried on in accordance with the provisions of this Constitution". 
by the United Nations General Assembly on 12 April, 1974 vide Resolution No. 3314 (XXIX)". The Court further noted:

The Soviet Union pressed for inclusion of "ideological aggression" and also "the promotion of the propaganda of Fascist-Nazi views, racial and national exclusiveness, hatred and contempt for other peoples". Iran pressed for inclusion of "indirect aggression, of intervention in another State's internal or foreign affairs", including "direct or indirect incitement to civil war, threats to internal security, and incitement to revolt by the supply of arms or by other means". Many States wanted the definition to include "economic aggression". Shri M. Jaipal of India advocated that in view of "modern techniques of coercion" the definition of aggression should have included "economic pressures" and "interventionary and subversive operations".

The Court also referred to the Statement of India's Representative to the Sixth Committee on the definition of Aggression which emphasized the need for a comprehensive definition. This Statement, the Court noted, also referred to the "unique type of bloodless aggression from a vast and incessant flow of millions of human beings forced to flee into another State" impairing thereby the economic and political wellbeing of the receiving victim State and threatening its very existence.

On the issue of the deportation of aliens, the Court noted that they also possessed several rights, and that the procedure for their identification and deportation should be detailed and elaborate in order to ensure fairness to them. The Court further noted:

The power to refuse admission is regarded as an incident of the State's territorial sovereignty. International Law does not prohibit the expulsion en masse of aliens. Reference has also been made to Article 13 of the International Covenant of 1966 on Civil and Political Rights which provides that an alien lawfully in the territory of a State party to the Covenant may be expelled only pursuant to a decision reached by law, and except where compelling reasons of national security otherwise require, is to be allowed to submit the reasons against his expulsion and to have his case reviewed by and to be represented for the purpose before the competent authority. It is important to note that this Covenant of 1966 would apply provided an alien is lawfully in India, namely, with a valid passport, visa, etc. and not to those who have entered illegally or unlawfully.

The Court held, inter alia, that the provisions of the IMDT Act were ultra vires the Constitution of India. 


\section{OTHER RELEVANT STATE PRACTICE}

\section{Measures to Eliminate International Terrorism ${ }^{26}$}

\section{Indian Statement in the Sixth Committee of the $60^{\text {th }}$ Session of the United Nations General Assembly Resolution on Agenda Item 108: Measures to Elimin- ate International Terrorism on 6 October 2005}

India noted that it attached highest importance to this agenda item. It also noted with satisfaction the report of the UN Secretary General on this item, which contained information submitted by States, and international organizations describing their activities relating to the prevention and suppression of international terrorism.

India further noted that the Declaration on Measures to Eliminate International Terrorism, adopted by the General Assembly Resolution 49/60 in 1994, was the first significant step taken by the United Nations in the fight against terrorism. It was the first comprehensive standard-setting instrument at the international level unequivocally to condemn all acts, methods and practices of terrorism as criminal and unjustifiable whenever and by whomever committed. It obliged States to refrain from organizing, instigating, assisting or participating in terrorist acts in the territories of other States, or from acquiescing in or encouraging activities within their territories directed towards the commission of such acts.

The Declaration, India pointed out, made clear that no considerations of political philosophical, ideological, racial, ethnic, religious or any other nature could justify criminal acts intended or calculated to promote a state of terror in the general public. Unfortunately, according to India, the Declaration continued to be flouted by some States that provided moral, material, financial and logistical sponsorship and support as well as provided arms to terrorists. It was of paramount importance to ensure that the Declaration was implemented sincerely by all States and that the standards it had set were effectively put into operation.

Referring to steps taken by India in strengthening international cooperation to combat terrorism, the Indian Statement further noted:

We have entered into several bilateral treaties in the areas of combating organized crime, narcotic drug offences, extradition and treaties of mutual assistance in criminal matters. These treaties facilitate the exchange of operational information and development of joint programmes to combat organized crime and terrorism. They also facilitate the transfer of fugitive offenders, suspected terrorists, etc., so that they can stand trial in the State in which the offence is committed. The mutual legal assistance treaties facilitate prosecution of offences, location of fugitives, and the transfer of witnesses and exhibits, all

${ }^{26}$ For the Indian Statements generally see http://meaindia.nic.in and http:// www.un.int/India/ 
of which play a vital role in the punishment of crime and prosecution of offenders. India is a party to twelve international sectoral conventions on terrorism that have been concluded under the aegis of the United Nations. We are also studying carefully the Convention for the suppression of Acts of Nuclear Terrorism with a view to consider becoming party to the Convention.

While emphasizing the need to conclude the negotiations on a Comprehensive Convention on International Terrorism during this Session, India stated:

Since the draft Convention under consideration does not raise any legal problems and the delay in its conclusion and adoption is by and large associated with the lack of political will of the few, demonstration of the political will is the need of the hour. As we are all aware, the question of the definition of an offence is a matter of precise legal language and is already reflected in the text of the draft Comprehensive Convention on International Terrorism now under consideration by this Committee. The objective of the Convention is to provide legal provisions which can be adopted in the criminal law instrument that would facilitate judicial cooperation, mutual assistance and extradition. The General Assembly has the central role in this process. If it abdicates its role, the Security Council, as in the past, will continue to deal with this issue in a partial piecemeal manner, governed by the political imperatives of the moment. That is not good for the development of law which needs to be broad-based and transparent. We all know the existence of a broadest possible agreement on all the draft provisions of the Comprehensive Convention on International Terrorism. However, the inclusion and exclusion of certain elements in Article 18 of the draft Convention remains a major outstanding issue. The Secretary-General's Report on the present agenda item indicates that, so far, the terrorism issue has been covered by 27 legal instruments. Making legal instruments to enrich a legal field is an ongoing process, be it in terrorism, human rights or in humanitarian law. It is impractical and inefficient to address an issue as complex as terrorism in one document. What is important is the timeliness. When the whole world waits for this Convention, we have to show flexibility and demonstrate political will. The August 2005 informal consultations gave a hope that we are near a compromise solution, which would enable agreement on the important Article 18 of the Convention. However, the issues which do not fit into the configuration of the present Convention, while important, are required to be handled separately in an appropriate format.

\section{Indian Statement in Explanation of Vote on Declaration on Human Cloning ${ }^{27}$}

\section{Agenda item 150: International Convention Against the Reproductive Cloning of Human Beings on 8 March 2005}

India, while expressing its regrets that the Sixth Committee had been unable to recommend to the plenary a text that was acceptable to all member States on a matter

${ }^{27}$ See for the Indian Statement http://meaindia.nic.in or http://www.un.int/india/ 
of paramount importance such as "The International Convention Against the Reproductive Cloning of Human Beings", pointed out that it had voted against the political declaration as some of the provisions of the Declaration could be interpreted as a call for a total ban on all forms of human cloning. India noted that it was:

[T]otally opposed to reproductive cloning owing to the doubtful nature of its safety, success, utility and ethical acceptability. However, we consider the merits of therapeutic cloning on a case by case basis within the bioethical guidelines laid down with the approval of the National Bioethical Committee. The Declaration voted upon today is nonbinding and does not reflect agreement among the wider membership of the General Assembly. Our approach to therapeutic cloning, thus, remains unchanged.

\section{Children and Armed Conflict ${ }^{28}$}

\section{Indian Statement on Children and Armed Conflict at the United Nations Security Council on 23 February 2005}

India noted that children had become increasingly involved, both as targets of violence and as combatants, in conflicts. During the last few years, it further noted, more than 500,000 children, recruited in 87 countries, with around 300,000 actively participating in combat, had been involved in conflict in some form or another.

Terming this as one of the "soft" challenges to international peace and security, India further noted the proposed action that could be initiated:

However, the Council can impose sanctions under Article 41 only if it has established, under Article 39, that there is a sufficient danger to international peace and security to justify them. Only States are Parties to Conventions, non-state actors are not bound by them. More important, most armed groups obey no laws, national or international. In some cases of internal conflict, non-state actors or rival political groupings may make offers of adhering to such instruments precisely to gain legitimacy or a political locus standi. Further, can a violation by a State of the provisions of the Convention on the Rights of the Child be construed as a threat to international peace and security? A body of standards for monitoring, including instruments which do not command universal acceptance, cannot be imposed on Member States. A Member State while otherwise committed to the norms and commitments on the promotion and protection of rights of children would be right in maintaining that it would not be bound by any instrument to which it is not a Party. The use of children in armed conflict has been aggravated by the proliferation of small arms and light weapons worldwide. These weapons are inexpensive, durable, small, lightweight, easy to maintain and small enough for them to handle. Illegal arms trafficking and poor monitoring of the legal trade make it easy for them to access such weapons. We are disappointed to note that the report does not call for the adoption of more legally

28 Ibid. 
binding commitments by Member States such as those on Marking and Tracing of Small Arms and Light Weapons and preventing the sale of arms to non-State groups.

While according national authorities primacy in gathering, vetting and compiling information at the country level as well as in the actions undertaken by UN field teams, India pointed out that it had:

[S] upported the concept of child protection advisors in UN peace-keeping operations as a means to complement the important work of the Special Representative of the Secretary General (SRSG) himself. We would, however, be deeply hesitant to involve the development agencies in developing countries from divesting or diluting their responsibilities in promoting and enhancing development cooperation and technical support. We have taken note of the proposal to constitute a Task Force on Monitoring and Reporting (TFMR) in countries where children and armed conflict is an issue. It has been proposed that the Task Force would involve "key members of the Child Protection Networks," including "UN and NGO actors who have the experience and are most directly concerned with monitoring and reporting." Who would select this 'cohesive group' from among the key members of the Child Protection Networks? It is also not clear to us why this Task Force would be more useful than the existing Child Protection Networks. In our view, the Task Force would only be effective if it can garner the trust and cooperation of all the main stakeholders who are involved in bridging the gulf between initiatives and implementation. We are surprised to note that even after four years of its existence, the Task Force on the subject at UN headquarters has not been able to formulate and compile guidelines on monitoring and reporting. The absence of such guidelines has, no doubt, led to the uneven quality of reporting on compliance and progress in the different situations where children are victims of armed conflict. Efforts towards ending the recruitment and use of children in armed conflict can only be effectively addressed when the guidelines i.e. what the stakeholders have to monitor and report on - are clearly outlined to them. Precise guidelines would not only help gather relevant information but also provide the necessary basis for formulation of policy. We remain wary about the efficacy of establishing "Neighbourhood Initiatives" to address children and armed conflict concerns at crossborder and sub-regional levels. While lessons learnt in one country may be useful in understanding some of the underlying factors behind the phenomenon, contextualising the problem of children in armed conflict is as important as addressing the problem itself. The specific political, social, historical and cultural contexts are unique to each conflict and the reasons why children are recruited or lured to join armed groups in one country may be entirely different from those in another. 


\section{Sustainable Development ${ }^{29}$}

\section{Indian Statement on Agenda Item 52: Sustainable Development at the Second Committee of the $60^{\text {th }}$ Session of the UN General Assembly on 2 November 2005}

India noted that the World Summit on Sustainable Development held at Johannesburg, while re-affirming the Rio Principles and the continued relevance of Agenda 21, focused on concrete action for the implementation of Agenda 21 and achieving sustainable development. The Summit also re-affirmed that addressing poverty was central to the efforts of developing countries in achieving sustainable development.

Noting that Climate Change was a global phenomenon and that developing countries had hardly contributed to the problem, India stated that it was committed:

[T]o the international regime represented by the UN Framework Convention on Climate Change (UNFCCC) and its Kyoto Protocol as the most appropriate tools to guide international efforts to protect global climate systems by reversing climate change in accordance with the principle of common but differentiated responsibilities. The main responsibility for climate change does not lie with developing countries. Yet, it has severe adverse impacts on precipitation patterns, ecosystems, agricultural potential, forests, water resources, and coastal and marine resources, besides increasing the range of several disease vectors in the developing countries.

Linking Intellectual Property Rights (IPRs) to Sustainable Development, India further stated:

One of the major constraints faced by developing countries in the implementation of the Johannesburg Plan of Implementation (JPOI) targets is the availability of necessary technologies. We need to look at this aspect if developing countries are to meet the targets. The IPR issue was successfully addressed with regard to HIV/AIDS. There is similar need for it to be addressed with regard to technologies for energy efficiency and for clean energy as well as for other areas of interest to developing countries. A network of R\&D institutes from developed and developing countries could also be established to engage in research in new technologies, particularly those that would be of interest to developing countries. All collaborative R\&D work done through the network could be made available to developing countries free of charge. Bio-diversity, the variety of life forms, is the foundation for maintaining the life-sustaining systems of this planet and fundamental to the fulfilment of human needs. At the Johannesburg Summit, we collectively agreed to significantly reduce by 2010 the current loss of biological diversity. There was also an acknowledgement that the achievement of this target would require the provision of new and additional financial, technological and technical resources to developing countries. Sharing benefits arising from the utilization of genetic resources is another area that

${ }^{29}$ For the Indian Statement see http://meaindia.nic.in and http://www.un.int/India/ 
requires attention. In this context, we welcome the decision of the Johannesburg Summit to negotiate, within the framework of the Convention on Biological Diversity, an international regime to promote and safeguard the fair and equitable sharing of benefits arising from the utilisation of genetic resources. We welcome the decision taken at the seventh meeting of the Conference of the Parties to the Convention on Biological Diversity to mandate the Ad hoc Open-ended Working Group on Access and Benefit Sharing to negotiate an international regime in implementation of this decision. We hope that, as a practical modality for benefit sharing, this regime will be able to include provisions for mandatory disclosure of the country of origin of genetic resources and prior informed consent in the IPR applications. India strongly supports sui generis systems for the protection of traditional knowledge that have been developed over millennia and ensure that the holders of traditional knowledge fully share in the benefits arising from the commercial utilization of this knowledge.

On desertification, India stated:

In the context of the UN Convention to Combat Desertification, we welcome the inclusion of land-degradation, desertification and deforestation as a focal area for financing by the Global Environment Facility. The effectiveness of these arrangements, however, would depend largely on allocation of additional resources to this focal area for financing the needs of affected countries.

\section{Comprehensive Convention on International Terrorism ${ }^{30}$}

\section{Indian Statement at Informal Consultations of the Sixth Committee on the Draft Comprehensive Convention on International Terrorism on 25 July 2005}

India welcomed the adoption of the International Convention for the Suppression of Acts of Nuclear Terrorism, initiated by the Russian Federation, and looked forward to its early entry into force. India noted that a vast majority of Member States had supported the adoption of the comprehensive Convention at the earliest. We urge all member States to capitalize on the new momentum at the UN and conclude swiftly the draft comprehensive Convention on international terrorism. This will complement the broad legal framework set out in Security Council resolutions and the thirteen UN counter-terrorism Conventions.

\footnotetext{
${ }^{30}$ For the Indian Statement generally see http://meaindia.nic.in
} 


\title{
International Trade and Development ${ }^{31}$
}

\section{Indian Statement on Agenda Item 50: International Trade and Development at the Second Committee of the $60^{\text {th }}$ UN General Assembly on 31 October 2005}

\author{
Referring to the Report of the Secretary-General, India noted:
}

[D]eveloping countries are often denied a level playing field to compete in global trade because developed countries use a variety of tariffs, quotas and subsidies to restrict access to their own markets and shelter their products. The international trading system is full of inequities - developing countries face non-tariff barriers and higher tariffs to their exports; tariffs escalate as the level of processing increases discouraging industrialisation in the developing countries. Besides, it is estimated that non-tariff barriers cost developing countries over USD 100 billion, almost twice the current level of Official Development Assistance. What is needed is to 'un-level' the playing fields in favour of developing countries, which has hitherto been favourable to developed economies, in order to make the multilateral trading system equitable. This would be in line with the call made as early as 1964 at the UNCTAD that "any definition must provide for elimination of all forms of discrimination, even those arising from so-called equal treatment. Treatment must be fair and fairness is not equality; fairness is the inequality needed to enable exploited peoples to attain an acceptable standard of living". The Secretary-General has also reminded us of the need for appropriate balance between national policy space and international disciplines and commitments, enshrined in the Sao Paulo Consensus. For defending livelihoods, sovereignty of the state is important and disciplines that erode the autonomy of policy space need to be reformed. The realisation of the development dimensions of the Doha Work Programme, especially a strong special and differential treatment component in the outcomes of negotiations in all areas - agriculture, NAMA and services - is a categorical imperative.

\section{Referring to Multilateral Trade Negotiations in preparation for the WTO Hong} Kong Ministerial, India stated:

Progress in the trade negotiations has been disappointing, considering the hopes raised after the July Framework Agreement. Time-lines have not been met for advancing technical work substantially, most notably to achieve a "first approximation" of the results targeted for the Hong Kong Ministerial - full modalities in agriculture and non-agricultural market access by end July 2005. A 'First Approximation' proved elusive; the attempts did not even approximate to an approximation. It is widely accepted that agriculture holds the key for unlocking progress in other areas of negotiations. The key issues of the formula for tariff reduction, flexibility for developing countries and the treatment of unbound tariffs remain unsettled in NAMA. There has been no significant movement in the post summer negotiations. Hence a clear political direction to break the current impasse is a categorical

${ }^{31}$ For the Indian Statement generally see http://meaindia. nic.in and http:// www.un.int/india/ 
imperative. As pointed out by the Secretary-General, ambitious steps forward in delivering on the promises made at Doha are needed, especially by developed countries.

India further stated:

The anticipated gains from agricultural reform and trade liberalisation by developed countries have till now eluded the developing countries. Out of the estimated contribution of USD 165 billion annually to global welfare gains by completely removing trade barriers in agriculture, the developing countries would only receive about a quarter. Moreover, agriculture is not only about trade - it has vital development ramifications. Food security and rural livelihood are of immense economic relevance and have a socio-political dimension in many developing countries. Demands for reduction of de minimis payments by countries go back on the July Framework Agreement and is unacceptable to developing countries with subsistence farming and predominantly resource poor farmers. Countries that demand such reductions should be aware of the perilous impact it would have on the food and livelihood security of millions of subsistence farmers in developing countries and in terms of the opportunities for development they would deny to developing countries. The operationalisation of proportionality and progressivity, the issue of flexibilities including the treatment of special products and the special safeguard mechanism for developing countries are, therefore, crucial. The Secretary-General has stressed the need for more equitable and fair conditions and for providing adequate development flexibility for nurturing the vital agriculture sector in developing countries, for agriculture trade to contribute to the achievement of MDGs, and for operationally effective and meaningful special and differential treatment for developing countries. We agree with the SecretaryGeneral. The fundamental objective of any Government is to defend the livelihood of ordinary people and a multilateral system that impinges adversely on it cannot long endure. Earlier this month, over 100,000 farmers rallied in India demanding that agriculture be taken out of the WTO.

On Services negotiations, India pointed out:

Significant results in the services negotiations remain essential to achieve a balanced outcome of the Doha Round. The Secretary-General notes that effective and commercially meaningful access in Mode 4 for developing countries' services suppliers is the area where the largest gain is expected and would contribute to the achievement of MDGs. It could be a win-win situation; restricting the movement of professionals across the world is unnatural and, ultimately, to the detriment of developed countries themselves. In order to protect the interests of developing countries, it is crucial that the basic GATS architecture and the agreed negotiating modalities and procedures are respected in the negotiations. It is equally important to provide for global horizontal disciplines which can protect negotiated gains in market access from arbitrary restrictions. 
Referring to TRIPS, India stated:

An important development issue concerns the amendment in the TRIPS Agreement to give effect to the General Council decision of August 2003 on 'TRIPS and Public Health' meant to address the problems faced by countries in accessing medicines at affordable prices when combating serious public health problems. The deadline set for devising a permanent solution by amending Article 31(f) has been extended several times. Developing countries, in order to receive a fair recompense for their biogenetic resources, have also been seeking amendments to the TRIPS Agreement to fully align it with the Convention on Biological Diversity and, in this context, to have the requirements of disclosure, prior informed consent and equitable benefit sharing incorporated in the TRIPS provisions on patents. On the issue of preference erosion, India believes that the main responsibility lies with the developed economies through implementation of their commitment to lower preferential rates to zero and, more importantly, through enhancing the utilization of GSP schemes by rationalizing the rules of origin. Notwithstanding the constraints of being a developing country, India would soon be finalising a bilateral package of preferential market access for LDCs into the Indian market. We welcome the 'Aid for Trade' initiative of the World Bank, which, we hope, will help loosen the supply side constraints in many developing countries.

\section{$\operatorname{IRAN}^{32}$}

\section{JUDICIAL DECISIONS}

Hæmophilia - Civil liability of State - Moral damages - Material damages

SABERI v. MINISTRY OF HEALTH, TREATMENT AND MEDICAL TRAINING, IRAN'S BLOOD TRANSFUSION ORGANIZATION AND IRAN'S BLOOD RESEARCH AND ANALYSIS COMPANY

\section{Judgment of Branch 1060 of the Tehran Court, 15 July 2004}

\section{Facts}

In 1983, two consignments of blood products were bought from a French company. Consumers of these products were infected with HIV and Hepatitis C because the products were contaminated with these diseases. On 2 November 2003, Counsel for Claimants (974 hæmophilia patients or their heirs) sued the Ministry of Health, Treatment and Medical Training, Iran's Blood Transfusion Organization and Iran's Blood Research Analysis Company under the Civil Liability Act, 1960 (hereinafter referred to as "CLA") and claimed both moral and material damages incurred by

32 Contributed by Jamal Seifi and Alireza Ebrahim-Gol, Shahid Beheshti University, Tehran. 
the victims. The Court ordered the defendants to pay both moral and material damages. An appeal was sought from this decision, but it was rejected. Appeal to the Supreme Court was also unsuccessful.

The Judgment

The judgment of the court is comprised of three parts, as follows:

A. Principle of civil liability of the defendant;

B. Amount of material damages and the mode of assessment of material damages, and

C. Moral damages and the criteria for moral damages.

Concerning the first, the Court based its judgment on the decision in the parallel criminal proceedings in this case and the reports of the General Inspectorate Organization and the Forensic Medicine Organization. The court also took into account the active role played by the Government and its affiliated organizations in the different social, economic and health concerns of its citizens in the present era and the various measures adopted by the Government in this regard. This active role carried the associated risk of Government actions resulting in damage to the citizens. Therefore, ethics, justice and legal logic require citizens to be compensated by the Government when its actions result in damages to the citizens, especially when the damage is highly burdensome.

The Ministry of Health had failed to declare the source of contamination and had subsequently rejected the factum of omission despite its confirmation by the accused in the related criminal case. Furthermore, the Blood Transfusion Organization, as a Governmental body, had the exclusive responsibility for the gathering and production of blood products, the distribution of the blood products, and the supervision of their quality. However, it had not obtained the licence for the production of the blood products; thus, it violated the law relating to their production.

These omissions and violations of law by Governmental bodies resulted in the irreparable moral and material damages incurred by claimants and, therefore, the Court found the defendants liable under Articles 1, 8, 11, and 14 of the CLA.

Regarding the second issue, the Court made a comparative study of precedents in cases involving infected persons demanding damages. The Court examined precedents from various countries such as Canada, Denmark, Brazil, Belgium, Italy, Bulgaria, India, Spain, Finland, Japan, Ireland, England, Sweden, Germany, France, South Africa, and Australia. The Court then classified the Claimants into four groups and awarded separate amounts of compensation for each group. The groups were:

1. Deceased patients infected with HIV;

2. Patients infected with HIV;

3. Patients infected with Hepatitis C, and

4. Persons who had become patients as a result of contact with hæmophilia and other consumers of these products. 
In respect of the final issue, the Court held that the Claimants' becoming infected with hazardous viruses such as HIV and Hepatitis $\mathrm{C}$ had led to their suffering from undefined fears, phobia, permanent anxiety, and feelings of insecurity. These, in turn, had affected their mentality and social interaction with other individuals and even members of their family, thus impairing their social reputation, and leading to the deprivation of their social rights such as the right to marriage, education and medical treatment. In these circumstances, any legal and social protection for these persons could lead to increasing their life expectancy and nourishing a positive spirit in them.

In determining the moral damages, the Court took into account factors such as age, gender, social status, especially professional status, marital status, parental status, education, divorce as a consequence of the infection, loss of marriage opportunities, depression, social pressures, length of illness and possibility of its recurrence, loss of job as a result of the infection, death of patients, and simultaneous infection with both viruses.

In awarding the moral damages, the Court considered obligations under Articles 164, 167, and 40 of Iran's Constitution and Articles 1, 2, 3, 5, and the latter part of Article 11 of the CLA and paragraph 3 of Article 2 of the International Covenant on Civil and Political Rights which was ratified by Iran in 1975 and considered as law under Article 9 of Iran's Civil Code.

Article 11 of the CLA provides:

In case Government officials, municipalities and their affiliated institutions in performance of their duties deliberately or recklessly cause damage to other person, they are themselves responsible. But in case the damages incurred are not attributable to them and [are] related to their negligence, the Government branches and affiliated institutions concerned will be liable.

The Court concluded that since the role of the Government in this case should be categorized as jure gestionis and not jure imperii; based on the general principle of law that no damage must remain uncompensated for, the Claimants were entitled to moral damages. The Court categorized the Claimants as those who were infected with Hepatitis C and those who were infected with HIV; it awarded separate amounts of compensation for each. Moreover, the Court, based on Articles 3-6 of the CLA and the latter part of Article 11, obliged the defendants to issue a formal apology in two widely circulated newspapers and correspondence with each of the Claimants. 


\section{NATIONAL LAWS ON INTERNATIONAL LAW MATTERS}

\section{Elimination of Child Labour}

\section{Council of Ministers Bye-Law in the Execution of the Prohibition and Prompt Action for Eliminating the Worst Form of Child Labour Act (PEWFCL)}

In accordance with its international obligations under the ILO Convention for the Prohibition and Prompt Action for Eliminating the Worst Form of Child Labour, the Iranian Parliament passed an Act called the PEWFCL on 17 May 2004. Subsequently, the Iranian Council of Ministers issued a bye-law for the execution of this Act.

In its first Article, it enumerates the worst form of child labour in 36 items. Article 2 provides that those who violate this bye-law will be sentenced to imprisonment from 91 days to one year, and will be subjected to the payment of compensation and cancellation of their work permit.

\section{Combating human traffic}

\section{Human Traffic Combat Act (HTCA)}

The Iranian Parliament, in pursuance of Iran's international obligations regarding combating human trafficking, passed a law called the HTCA on 19 July 2004. In its first Article, this Act gives a definition of "human trafficking"; in the second article, it defines acts which are constructive human trafficking. Article 3 provides that in the event that the act of the offender is amongst those that are enumerated in Iran's Islamic Penal Code, s/he will be convicted according to that law. Otherwise, $\mathrm{s} /$ he will be convicted to imprisonment for two to ten years and make payment of compensation.

\section{Respect for legitimate freedoms and citizens' rights}

\section{Respect for Legitimate Freedoms and Observance of Citizens' Rights Act}

In pursuance of Iran's international obligations under the human rights instruments, the Iranian Parliament passed an Act on 5 May 2004 named the Respect for Legitimate Freedoms and Observance of Citizens' Rights Act.

Article 1 of this Act provides that the discovery, investigation, and prosecution of crimes must be based on laws and with judicial orders, and it prohibits unnecessary detentions. Other Articles referring to the general principle of law that each person is presumed innocent unless the contrary is proved provide for the observance of the rights of an accused and the complainant. Article 5 provides that the case must be referred to a competent court within the due legal time limit.

During the process of investigation and interrogation, the eyes of the accused must not be closed and officers responsible for the inquiry must not cover their faces 
or sit behind the accused, and must refrain from other acts which may humiliate the accused. Article 9 expressly condemns torture and provides that violators must be seriously punished.

\title{
JAPAN
}

\section{JUDICIAL DECISIONS ${ }^{33}$}

\section{Diplomatic Privileges of the Staff who is National of the Receiving State Vienna Convention on Diplomatic Relations}

\author{
$X$ v. STATE OF JAPAN
}

\section{Tokyo District Court, Decision, 10 November 2004 1893 Hanrei Jihou [Judicial Reports] 160 [2005]}

$\mathrm{X}$ is a Japanese citizen working at the Embassy of Sri Lanka in Tokyo. X was employed by the Embassy as a staff clerk-typist in August 2002. X's major responsibilities are to serve as an interpreter, to work on translations, or to provide help for arrangements to welcome leading figures when they come from Sri Lanka. Driving a car is not part of X's original work profile. One day, in compliance with the visiting Minister of Land of Sri Lanka, and after obtaining the authorization of the Embassy of Sri Lanka, X took the Minister and his family in X's own car, showed them around Tokyo city for shopping, and deposited them at the hotel where they were staying. After that, on his way home from the hotel X caused a traffic accident in which a motorcycle rider suffered severe cuts that took two months to heal completely. X, who was prosecuted because of this traffic accident, claimed that, being on the staff of a foreign Embassy, he should enjoy the privileges and immunities on the basis of Article 38(2) of the Vienna Convention on Diplomatic Relations, and therefore, the public action in the case must be dismissed.

The Tokyo District Court dismissed the claim of the plaintiff and ordered him to pay one hundred and fifty thousand yen as a fine to the plaintiff. Its reasoning is as stated below.

Firstly, Article 38(2) of the Vienna Convention provides that "other members of the staff of the mission and private servants who are nationals of or are permanently resident in the receiving State shall enjoy privileges and immunities only to the extent admitted by the receiving State". X is apparently "other members of the staff of the mission" and "nationals of ... the receiving State". However, a problem remains as regards the wording "the extent admitted by the receiving State". In other words, it is important to determine whether the Japanese Government, as the receiving State, has indeed authorized privileges and immunities to other members of the staff of

${ }^{33}$ Contributed by Tanaka Norio, Professor of International Law, Ryukoku University, Kyoto, Japan. 
the mission and nationals of the receiving State, or it has not. The Court found that there were no such laws and regulations in Japan which authorize privileges and immunities as mentioned above.

Secondly, according to the defence attorney, other members of the staff of the mission and nationals of the receiving State shall enjoy immunities from criminal jurisdiction concerning their acts performed in the course of their duties under custom in conformity with customary international law. However, it is not only obscure as to what is meant by "custom in conformity with customary international law", but there is also no evidence to show the establishment of such customary international law.

On the contrary: according to international lawyers before the Court, the drafting process of Article 38(2) of the Vienna Convention shows that there was no agreement on the extent of privileges and immunities authorized to "other members of the staff of the mission and private servants who are nationals of or permanently resident in the receiving State". Therefore, the Court found that the contention submitted by the defence attorney cannot be accepted.

Nationality Clause of National Pension Law - Non-application of National Pension Law to Korean Residents not having Japanese Nationality - Direct Applicability of Article 2 (2) of International Covenant on Economic, Social and Cultural Rights as a self-executing treaty - Article 26 of International Covenant on Civil and Political Rights

X et al. v. STATE OF JAPAN

Osaka District Court, Decision, 25 May 2005

1898 Hanrei Jihou [Judicial Reports] 75 [2005], 1188 Hanrei Taimu [Law Times Reports] 254 [2005]

All of the plaintiffs are foreigners who have Korean nationality and reside in Japan. The National Pension Act was not made applicable to foreigners who do not have Japanese nationality. After Japan ratified the 1951 Convention on the Status of Refugees, the nationality clause of the National Pension Act was abolished through its amendment. However, Korean people were still excluded from the application of the modified National Pension Law. They claimed that they are victims of discrimination because of the nationality clause of the National Pension Act and this is in violation of Article 14 of the Japanese Constitution, Article 2(1), (2) and Article 9 of the International Covenant on Economic, Social and Cultural Rights, and Article 26 of International Covenant on Civil and Political Rights.

Firstly, the Osaka District Court dismissed the claim of the plaintiffs as regards Article 14 of Japanese Constitution, which stipulates equality of all peoples under law, by stating as follows:

Deciding applicable personal scope or contents of the National Pension Act, the legislative body has discretionary power to some extent. Therefore, the use of power by that is not 
appropriate for judicial judgment, except as it lacks reasonableness and apparently seems to be an egregious deviation or abuse of the discretionary power. Exclusion of Korean people from application of National Pension Act is not necessarily discrimination which is prohibited under [the] Japanese Constitution.

Secondly, the Court considered whether the National Pension Act including the nationality clause is contrary to Article 9 of the International Covenant on Economic, Social and Cultural Rights, and Article 26 of the International Covenant on Civil and Political Rights, or not. On this point, the Court at first noted as follows:

Article 9 of International Covenant on Economic, Social and Cultural Rights does not give a concrete right to individuals without any domestic law based on Article 9, for demanding any particular benefits in social security. As far as Article 2 (1) of the Covenant is concerned, the State Party shall not be immediately obliged to enact domestic law implementing any provisions of the Covenant, but she has the discretionary power for deciding when or what laws and regulations should be enacted.

However, if a domestic law has been enacted to put the Covenant's provisions into effect, any discrimination shall be prohibited under Article 2(2) of the International Covenant on Economic, Social and Cultural Rights in all aspects of the application of its domestic law. Article 2(2) is a self-executing provision regardless of one of the provisions of the Covenant, and can be directly applied in a domestic court, just as can Article 26 of the International Covenant on Civil and Political Rights.

As shown above, the Court found that the International Covenant on Economic, Social and Cultural Rights can be applied directly in a domestic court of Japan, and if a domestic law has been enacted for the purpose of implementing the Covenant, any discrimination on the basis of nationality shall be prohibited in the stage of application of the law concerned. However, the Court dismissed the claim of the plaintiffs.

\section{NATIONAL LAWS ON INTERNATIONAL LAW MATTERS ${ }^{34}$}

\section{Entry into force of the Law to implement the Geneva Conventions and Addi- tional Protocols}

On 28 February 2005 the Law concerning the Punishment of the Grave Violations of International Humanitarian Law (Law No.115, 2004) entered into force some ten months after its promulgation. This Law was enacted at the same Diet session in 2004 as the accession to the 1977 Geneva Protocols I and II Additional to the Geneva

\footnotetext{
${ }^{34}$ Contributed by Aoki Takashi, Faculty of Law, Seiwa University, Chiba, Japan.
} 
Conventions of 1949 was approved. ${ }^{35}$ An additional clause of the Law provides that it comes into effect on the date of the entry into force of the Geneva Protocol I for Japan.

Articles 3 to 6 of the Law lay down the following four criminal acts and the corresponding penalties for them:

(a) A person who during his act of hostilities destroys such important cultural property as specified by a Government ordinance is liable to imprisonment with hard labour for seven years or less;

(b) A person who, with power of repatriation of prisoners of war, delays such repatriation without good reason is liable to imprisonment with hard labour for seven years or less;

(c) A person who transports nationals or residents of the occupied State for their settlement in its occupied area is liable to imprisonment with hard labour for five years or less;

(d) A person who, with powers to manage emigration, interferes without good reason in civilians emigrating from the occupied area is liable to imprisonment with hard labour for three years or less.

In accordance with Article 7, all these crimes are made punishable even when they are committed outside Japan under Article 4bis of the Penal Code which provides that "[i]n addition to those provided for in Articles 2 to 4, this Code shall also apply to every person who has committed the crimes provided in Part 2 for which Japan is under a treaty obligation to punish even when they are committed outside Japan" [unofficial translation]. This clause was added in 1987 to implement the Hostage Convention and the Convention for Protection of Internationally Protected Persons to which Japan was about to become party. In the Diet deliberations, an additional effect of the new article was referred to as the facilitation of the prompt participation of Japan to the conventions which stipulate the obligation to punish the extraterritorial crimes, by making it possible that any crime specified in Part 2 be punished by applying the conventions to the acts committed outside Japan as requested by such conventions. ${ }^{36}$

As to the Four Geneva Conventions of 1949, Japan acceded to them in 1953 in conformity with its declaration at the San Francisco Peace Conference of 1951, yet no legislative action was found to be required to bring them into effect. However,

\footnotetext{
35 For the outline of the legislation and comment, see http://www.ritsumei.ac.jp/acd/cg/law/lex/ rlr22/Legi.pdf, pp.155-7. The statement of the Foreign Ministry on the legislation can be found at $<$ http://www.mofa.go.jp/policy/security/legistlation.html $>$.

${ }^{36}$ Minutes of the Diet, the House of the Representatives, Committee on Judicial Affairs, No.3, 15 May 1987, the 108th Session of National Diet, at 29
} 
now extraterritorial crimes to be punished under the Geneva Conventions have been added to the application of Article 4bis of the Penal Code. ${ }^{37}$

\section{OTHER RELEVANT STATE PRACTICE ${ }^{38}$}

Bilateral Talks with China concerning the Seabed Development in the East China Sea

In May 2004, it was reported in the press that China had commenced construction of installations for the commercial production of natural gas from the offshore field Chunxiao located a few miles west of the Japanese-claimed median line in the East China Sea. The distance between the baselines of the two countries is less than 400 nautical miles. The Japanese legislation prescribes the limit of maritime areas in relation to neighbouring States as the median line. ${ }^{39}$ China has conducted extensive exploration in the waters around the line since the mid-1990s, ${ }^{40}$ and reportedly discovered six gas fields, including Chunxiao and Duangqiao, near the median line. Some of them have already been in the commercial production stage.

In June 2004, the news led the Japanese Government to express its grave concern and to request for information on the geological facts and Chinese activities. The Government stated, inter alia, that the sites where commercial drillings were about to begin under the Chinese licence and the gas deposit in the sites might well extend into the Japanese side of the median line. In the next month, Japanese companies conducted a series of physical explorations of the seabed area in the Japanese side of that line under the licence issued by the Japanese Government; the results clarified the probable unity of the deposits. China had, reportedly, protested the Japanese action as a violation of Chinese sovereignty and interest, and mobilized their naval fleet to the waters near the gas fields.

Since October 2004, both Governments have had three rounds of consultations concerning the disagreement on the East China Sea and other matters. The second and the third meetings were held in May and September-October of 2005.

At the first consultation, China only explained the geological features, in general, of the Chunxiao structure on which Japan had requested the detailed information, and China stated that production in the structure would not affect the resources in the Japanese waters. Concerning the other licensed sites, China stated that although

\footnotetext{
37 An additional clause to the code amended (Law No. 52, 1987) expressly enlarged the application of the provision of Article 4 bis to the crimes to be punished under the Geneva Conventions even when they were committed outside Japan.

38 Contributed by Aoki Takashi, Faculty of Law, Seiwa University, Chiba, Japan.

39 Arts. 1 and 2, Law on the EEZ and the Continental Shelf (Law No.74, 1996), <http: //www.un. org/Depts/los/LEGISLATIONANDTREATIES/PDFFILES/JPN_1996_Law74.pdf. >

40 Japan has lodged a protest against the activities engaged in on the Japanese side of the median line. In 2001, a framework of the mutual prior notification of marine research activities was established for research taking place in the waters near the other country in the East China Sea, and notes exchanged to bring it into effect.
} 
it had the right to place the site in the waters covered by Chinese sovereign rights, it is abstaining from carrying out practical work on site.

The second meeting was reported to contribute to understanding each other. However, the Japanese demand for information and suspension of Chinese development work at Chunxiao Gas Field was not accepted by China. As regards the boundary delimitation, it became clear that fundamental differences existed in both sides' respective positions, including in the disputed area. It was agreed that a consultation of legal experts should promptly be held. Whereas China proposed principles on joint development, Japan pointed out its inherent difficulties. It was decided that each country should examine the possibility to resolve the issue through joint development.

The third round results, as announced by the Japanese Foreign Ministry on the web, ${ }^{41}$ need briefly to be stated.

(a) As regards the development of natural resources by the Chinese side: although both sides shared the common recognition that this was a matter to be resolved urgently, the Japanese side demanded that the Chinese side provide information and discontinue the development work. However, the Chinese side responded that the development had been conducted in the undisputed waters and that it could consider the provision of information after an agreement in principle had been reached on the joint development.

(b) To the Japanese proposal regarding the joint development and the demand for suspension of Chinese development work, China replied that they would seriously study the proposals and present their views at the next consultations.

(c) On the debate over the joint development, both sides shared the view that any joint development to be carried out as an interim arrangement should not affect future negotiations over maritime demarcation, and should be mutually beneficial.

(d) The legal experts exchanged their interpretations of international law applicable to the case in the East China Sea. Although opinions differed, both sides deepened their understanding of the other's stance.

Although the issues between the parties are being identified gradually through negotiations, even more intensive consultations seem to be required for them to reach an equitable solution. For the legally justified resolution of this matter, additionally, the political ramifications between the two countries have to be ameliorated, including the increasing frictions over the "past history', ${ }^{42}$ and the rivalry on the economic and naval balance in the East Asia. Continuing observation is called upon on this case.

${ }^{41}$ See Japan-China Consultations on the East China Sea and Other Matters (30 September to 1 October, Tokyo), <http://www.mofa.go.jp/region/asia-paci/china/consult0509.html>

${ }^{42}$ For the Prime Minister's statement on the point, see $<\mathrm{http}: / /$ www.mofa.go.jp/announce/announce/ 2005/8/0815.html> 
KOREA $^{43}$

JUDICIAL DECISIONS

\author{
Trade Agreement - Right to Property - Right to Freedom of Information \\ AGREEMENT FOR TRADE OF GARLIC BETWEEN THE REPUBLIC OF KOREA \\ AND THE PEOPLE''S REPUBLIC OF CHINA
}

\title{
16-2(B) Korean Constitutional Court 568, 2002Hun-Ma579, 16 December 2004
}

\section{Background}

In order to settle the disputes regarding the South Korean measure restricting the import of garlic produced in China and the termination of import by China of South Korean mobile telephones, the Korean Government trade representative, with the Chinese counterpart, signed on 31 July 2000 an agreement concerning the trade of garlic between the Republic of Korea and the People's Republic of China to the effect that the restriction upon the import of garlic produced in China that had already been imposed by South Korea for the previous three years would be maintained. The Government, thereupon, disclosed through a press release that the amount of garlic to be imported from China was practically frozen for the three years to reach the level of the amount imported in 1999, or less. However, in fact, the supplemental document to the above agreement with China contained the additional agreement stating that the "private enterprises of the Republic of Korea may freely import garlic from the date of 1 January, 2003", which the Government did not disclose. The Complainants, who were cultivating garlic, filed the constitutional complaint in this case claiming that their right to know and right to property had been infringed by the above additional agreement and the failure to notify such additional agreement.

The Judgment

The Constitutional Court, in the opinion of all justices with the exception of the separate concurring opinion of one justice, dismissed the constitutional complaint. The summary of the judgments is stated below.

\section{Summary of the Majority Opinion of Eight Justices}

The measure restricting the import of garlic produced in China is merely to provide a certain amount of extra time for countermeasure by temporarily protecting the agricultural households that have failed to adjust themselves to the concrete economic situation that confronts them, and not to secure a legal situation beneficial

43 Contributed by Professor Eric Yong-Joong Lee, at Dongguk University College of Law, Seoul, Korea. 
to the agricultural households cultivating garlic by maintaining the import barrier against the garlic produced in China for a long term or without a temporal limit. Therefore, no legally justifiable expectation or interest whatsoever can be endowed to the agricultural households cultivating garlic with respect to the renewal of the above import restriction measure; neither may the property right of the agricultural households cultivating garlic be deemed to be restricted by the Government's decision to not renew the import restriction measure. In addition, the opportunity to cultivate garlic in an economically manageable way with constant profit is not an entity guaranteed as a basic right. Thus, even if they should discontinue the cultivation of garlic due to the exacerbation of the business situation, the freedom to choose an occupation may not be deemed to have been affected thereby. Therefore, as there is no question of an infringement of the basic rights of the Complainants such as their property right, the constitutional complaint challenging the above agreement is unjustified.

The Government's obligation to disclose, which is derived from the right to know, exists only upon the citizen's act of active collection of information and especially the request for disclosure of specific information unless there is an exceptional situation. Therefore, in this case where there was no request for disclosure of information, the Government was under no obligation to disclose in advance the import liberalization measure part of the agreement concerning the trade of garlic between the Republic of Korea and the People's Republic of China.

In addition, although an obligation to disclose corresponding to the right to know may be recognized as an exception in the case of certain categories of treaties for which there exists the obligation to disclose even without request for disclosure, the above agreement with China may not be deemed as the final decision over the renewal of the emergency import restriction measure even pursuant to the supplemental document at issue in this case because such a decision should go through the process of investigation and recommendation of the Trade Committee under the applicable law. Thus, it may not be deemed that the Government as the matter of the Constitution should necessarily give such agreement the effect identical to that of domestic law by way of promulgation.

As such, there is no obligation on the part of the Government to disclose the supplemental agreement with respect to the import of garlic. Therefore, the constitutional complaint challenging the failure to act that is based on the premise of the Government's obligation to disclose is unjustified.

\section{Summary of the Separate Concurring Opinion of One Justice}

The above agreement concerning the trade of garlic is equivalent to the so-called public notice-type treaty, which under the domestic law has the status equivalent to public notice and does not have the status of a statute. The authority of the executive branch of the Government to enter into such public notice-type treaties accompanies in its own nature a very broad discretion. Such discretion of the executive branch is fundamentally strategic and tactical; further, it may not depart from mutualism. Therefore, the constitutional complaint in this case should be dismissed, 
as the exercise of the authority by the Government and the content thereof with respect to the conclusion of the public notice-type treaty may not be the subject matter of review on a constitutional complaint unless there is a clear digression from or abuse of the procedure determined by the Constitution and the statute.

\section{Freedom of Renunciation of Nationality - Military Service}

THE UNCONSTITUTIONALITY OF THE NATIONALITY LAW ARTICLE 12, PROVISION 1

\section{Korean Constitutional Court, 26 August 2004 (No. 2002Hunba3)}

Background

The Applicant was born in the United States and his parents were both Korean nationals. The Applicant had dual nationality of Korea and America. Having reached the age of 19, the Applicant applied for renunciation of Korean nationality.

The Minister from the Ministry of Justice decided that the Applicant was over 18 and had been inducted into the first national military service by the time he had applied for renunciation; in accordance with Article 12 of the Nationality Law of the Republic of Korea and under paragraphs 3 and 4 of Article 16 of the Regulations for the Implementation of Nationality Law, the Applicant should not apply for renunciation of Korean nationality unless his duty of military service had been fulfilled or exempted lawfully. Therefore, the decision was for the dismissal of the application for renunciation of Korean nationality. The Applicant applied to the Court for retraction of the above-mentioned decision.

In the Court proceedings, the Applicant also requested the Court to decide whether the Proviso in paragraph 1 of Article 1 of the Nationality Law of the Republic of Korea was in violation of the Constitution. The Court rejected the submissions of the Applicant. Then, the Applicant presented a petition to the Constitutional Court.

\section{The Judgment}

It is stipulated in paragraphs 3 and 4 of Article 16 of the President Order on the Implementation of the Nationality Law (hereinafter referred to as the "President's order") that male citizens over the age of 18 with dual nationality who have been inducted into the first national military service should not apply for renunciation of Korean nationality unless their duty of military service had been fulfilled or exempted lawfully.

In accordance with paragraph 1 of Article 12 of the Nationality Law of the Republic of Korea, citizens of the age of 20, with dual nationality, shall select one nationality before the age of twenty-two.

As for the duty of military service, the legal provisions provided that citizens with dual nationality and in accordance with the circumstances provided in the President Order shall select one nationality within two years after the removal of 
the circumstances. It is implied that some more provisions in relation to selection of nationality shall be added under other specified circumstances. However, if there are so far no relevant provisions applied to such circumstances, it makes a reservation to authorize the concerned department to promulgate the order under the name of the President, that is, if there are some circumstances related to the fulfilment of the duty of the military service, the selection of nationality shall be made within two years after the removal of the circumstances, but the provisions on the circumstances shall be made by the authorized department under the name of the President's order.

In this case, as there is no relevant provision directly applied to restrictions on the selection of nationality for citizens with dual nationality and duty of military service, the reservation has been made to authorize the concerned department to promulgate the order under the name of the President to make the provisions on nationality selection. Therefore, to make a judgment on whether the legal provisions of this case are unconstitutional means to make a judgment as to whether the authorizing procedure is unconstitutional. This would be different from making a judgment on whether the provisions of the President's order on the Implementation of Nationality Law are unconstitutional or not.

Article 75 of the Constitution of Republic of Korea provides that the President shall provide a clearly defined scope in the President's order. This would mean that the basis of enabling legislation has been determined and, at the same time, the authorization is limited in the clearly defined scope.

The Constitution of Republic of Korea clearly provides that National Defense and Military Service are inevitable and intrinsic constitutional values and in accordance with the Military Service Law it is the duty of every male citizen of the Republic of Korea to perform military service. Therefore, any person with dual nationality, one of them being Korean, shall not be exempted from the duty of Military Service.

In this case, it is the premise of the legal provisions that every Korean male citizen, even those with dual nationality, shall fulfil the duty of military service. The legislative purpose is to prevent the usage of the nationality selection system as means of avoiding the obligation of military service. Therefore, the legal provisions in this case do not violate the Constitution. 


\title{
JUDICIAL DECISIONS \\ NEPAL $^{44}$
}

Right to equality - Positive discrimination should not be used irrationally

\begin{abstract}
ADV. SHYAM KRISHNA MASKEY AND OTHERS V. HIS MAJESTY'S GOVERNMENT OF NEPAL, MINISTRY OF LAW, JUSTICE AND PARLIAMENTARY AFFAIRS AND OTHERS
\end{abstract}

\section{Special Bench of the Supreme Court of Nepal on 6 December 2005 13 Supreme Court Bulletin 20}

\section{Introduction}

The Supreme Court of Nepal has emphasized that the State should not discriminate between men and women while giving effect to international law or implementing domestic laws. The writ petitioner had brought a writ petition before the Supreme Court of Nepal asking to declare null and void the eleventh amendment to the National Code, 1963 of Chapter 12 sections 4(a) ${ }^{45}$ and 4(c $)^{46}$ on Husband and Wife, which allow a married woman to obtain partition out of the property of a husband even after getting divorced. The writ petitioner had claimed that a married woman would gain more property than a man when she divorces and remarries (as many times as she does so). Under such a situation, according to the writ petitioner, the woman could obtain a double right to partition whereas a man would be responsible for sharing his property irrespective of the fact of the divorce. On the other hand, men are responsible for providing alimony to a divorced wife until she remarries or for a period of five years, whereas women having an income are not responsible to provide alimony to a divorced husband even though the husband has no source of income. The amended provisions of the National Code were introduced to give

\footnotetext{
${ }^{44}$ Contributed by Surendra Bhandari, Executive Director, Law Associates Nepal, Kathmandu.

${ }^{45}$ Section 4(a) of Husband and Wife provides that, "When a husband and wife get divorced pursuant to Section 1 of this chapter, the court shall decide the divorce only after the property of husband is partitioned between them. If the husband who is getting divorce has not acquired ancestral property, the court shall order a partition between the coparceners and out of the share of the husband, grants partition to the wife who is getting divorced. Until partition is accomplished, the wife should be provided monthly maintenance by the husband. If such woman does not remarry or if she does not bear children after she remarries, the children from her former husband shall be entitled to have a share in the property that she had obtained from her former husband. If there are no children from her former husband, the former husband shall be entitled to her property after her death".

${ }^{46} I d$. Section 4(c) stipulates that if a man divorces who does not have property but does have an income, in such a situation, the court shall provide from her former husband on the basis of his income maintenance to the divorced woman until she remarries.
} 
effect to the Convention on Elimination of All Forms of Discrimination against Women, 1979 (CEDAW). But unlike CEDAW, the amended provisions were discriminatory to men. Therefore, according to the writ petitioner, the discriminatory provisions had to be declared null and void.

The Supreme Court acknowledged that the issues raised by the petitioner were important in terms of law and justice. The Constitution guarantees that no discrimination shall be made against any citizen in the application of general laws on the ground of sex. The tendency of enacting laws which discriminate between men and women is against the rule of law. No son, daughter, husband or wife should be denied an equal share to property. A legal provision which makes a man liable for providing a share of property more than once to a woman or providing alimony to a wife having equal or greater income in the case of divorce cannot be considered as fair, just and reasonable.

The Supreme Court further noted that it is a special duty of the State to respect and give effect to the provisions of the international human rights instruments, including CEDAW to which Nepal is a party, without maintaining any discrimination between men and women. The Court directed the Government to carry out a comprehensive study on the discriminatory provisions in the different Acts relating to family law and property rights and to review their consistency with the Constitution of the Kingdom of Nepal, $1990^{47}$ for ending any form of discrimination between men and women.

The Court noted that the legal provisions in question seem inconsistent with the Constitution and related human rights instruments to which Nepal is a party and also appear discriminatory. However, to declare them ultra vires on the basis of their visible inconsistency with the Constitution and related human rights instruments was not a viable remedy to the problem as it could immediately lead to multiple problems in society. It would also be interfering with legislative wisdom and competency. It would also affect the sub judice divorce cases in different courts. It would also create discrimination against women since there were no legal provisions that could remove discrimination against women. Therefore, while the Court considered the matter at hand a very serious issue of public concern and importance, it held that it would be unwise to test the constitutionality of the impugned legal provisions. Against this background, the Court issued a directive to the Government to review the relevant provisions through obtaining input from an expert body and to initiate a process of enacting new laws or to amend the existing laws to make them consistent with the Constitution and related international human rights instruments. The Court also ordered the Government to submit a study report prepared by an expert committee before the Inspection and Supervision Division of the Supreme Court of Nepal.

${ }^{47}$ Recently, in January 2007, the 1990 Constitution has been withdrawn by an Interim Constitution 2007. However, provisions on non-discrimination and equality in the Interim Constitution are similar to those in the 1990 Constitution. 


\section{Gender Justice - International law prevails over domestic law in case of in- consistency between domestic law and international law}

\section{LILY THAPA AND OTHERS v. PRIME MINISTER AND OTHERS}

\section{Special Bench of the Supreme Court of Nepal on 15 December 2005}

In this case, the Supreme Court of Nepal declared Section 2 of the Chapter on Women's Property Rights of the National Code, 1963 ultra vires of Articles 11(1 $)^{48}$ and $17^{49}$ of the Constitution of the Kingdom of Nepal, 1990, Article $26^{50}$ of the International Covenant on Civil and Political Rights (ICCPR) 1966, Articles $2^{51}$ and $3^{52}$ of the International Covenant on Economic, Social and Cultural Rights (ICESCR) 1966, and Article1, ${ }^{53} 2,{ }^{54} 3,{ }^{55}$ and $15^{56}$ of CEDAW 1979.

The impugned Section 2 provides that unmarried, married or widowed women who live separately from their family can on their own sell or transfer the whole moveable property and half of the immovable property without obtaining the consent

48 Article $11(1)$ of the Constitution of the Kingdom of Nepal, 1990 provides, "All citizens shall
be equal before the law. No person shall be denied the equal protection of the laws."
49 Id. Art. 17 (1) provides, "All citizens shall, subject to the existing laws, have the right to acquire, own, sell and otherwise dispose of, property."

50 Art. 26 of the International Covenant on Civil and Political Rights, 1966 provides, "All persons are equal before the law and are entitled without any discrimination to the equal protection of the law. In this respect, the law shall prohibit any discrimination and guarantee to all persons equal and effective protection against discrimination on any ground such as race, colour, sex, language, religion, political or other opinion, national or social origin, property, birth or other status."

51 Art. 2(2) of the International Covenant on Economic, Social and Cultural Rights, 1996 provides, "The States Parties to the present Covenant undertake to guarantee that the rights enunciated in the present Covenant will be exercised without discrimination of any kind as to race, colour, sex, language, religion, political or other opinion, national or social origin, property, birth or other status."

52 Id. Art. 3 provides, "The States Parties to the present Covenant undertake to ensure the equal right of men and women to the enjoyment of all economic, social and cultural rights set forth in the present Covenant."

53 Art. 1 of the Convention on the Elimination of All Forms of Discrimination against Women, 1979 provides, 'For the purposes of the present Convention, the term 'discrimination against women' shall mean any distinction, exclusion or restriction made on the basis of sex which has the effect or purpose of impairing or nullifying the recognition, enjoyment or exercise by women, irrespective of their marital status, on a basis of equality of men and women, of human rights and fundamental freedoms in the political, economic, social, cultural, civil or any other field."

54 Id. Art. 2(a) provides, "States Parties condemn discrimination against women in all its forms, agree to pursue by all appropriate means and without delay a policy of eliminating discrimination against women and, to this end, undertake: (a) To embody the principle of the equality of men and women in their national constitutions or other appropriate legislation if not yet incorporated therein and to ensure, through law and other appropriate means, the practical realization of this principle."

55 Id. Art. 3 provides, "States Parties shall take in all fields, in particular in the political, social, economic, and cultural fields, all appropriate measures, including legislation, to ensure the full development and advancement of women, for the purpose of guaranteeing them the exercise and enjoyment of human rights and fundamental freedoms on a basis of equality with men."

${ }^{56}$ Id. Art. 15(1) provides, "States Parties shall accord to women equality with men before the law." 
of the family members; they do, however, need to obtain the consent of their family members (from parents in the case of unmarried women, the consent of the husband for married women, and the consent of the adult children for a widow) to sell or transfer the whole immovable property.

The question before the Supreme Court concerned whether or not the impugned provision had acknowledged an independent personality and personhood of women. Further, the writ petitioner had raised an issue: that when women are subjected to the requirement of obtaining the consent of family members to selling or transferring their personal property, this amounts to discrimination against women and violates the provisions of the 1990 Constitution and various provisions of different international instruments including the ICCPR and CEDAW. Therefore, according to the writ petitioner, the impugned provision had to be declared ultra vires.

The Court agreed with the submission of the petitioner and delivered a judgment declaring the impugned Section 2 ultra vires to the Constitution, ICCPR, ICESCR and CEDAW.

\section{Policy Matter - Court cannot intervene in policy matter but can test compatibil- ity of domestic law with international law}

\section{ADV. PRAKASH MANI SHARMA AND OTHERS v. PRIME MINISTER AND OTHERS}

\section{Special Bench of the Supreme Court of Nepal on 15 December 2005}

In this case, the Supreme Court of Nepal declined to intervene in the wisdom of legislature, especially on the choice of options in formulation of a law. However, the Court issued a directive order to His Majesty's Government of Nepal to review Section 16 of the Chapter on "Partition" in the National Code, 1963 in the light of CEDAW, ICCPR and ECESCR.

Section 1 of Chapter on "Partition" in the National Code, 1963 provides that each member of a family irrespective of sex and age shall have equal rights to ancestral property. However, the impugned Section 16 provides that the property received by a daughter from partition reverts (restitution in integrum) back to the maternal family members when she marries. The writ petitioner had challenged the impugned Section 16 claiming that it discriminated between men and women in the context of the exercise of proprietary rights; for the impugned Section 16 makes the proprietary right of women a contingent right whereas it prescribe no similar conditions to the property rights of men. According to the writ petitioner, this provision of domestic law (National Code, 1963) was inconsistent with Article 11 (equality provision) of the Constitution of the Kingdom of Nepal, 1990 and Articles 1, 2, 3, 15 and $16^{57}$ of CEDAW, Article 26 of ICCPR, and Articles 2 and 3 of ICESCR.

\footnotetext{
57 Id. Art. 16 provides, "States Parties shall take all appropriate measures to eliminate discrimination against women in all matters relating to marriage and family relations and in particular shall ensure, on a basis of equality of men and women."
} 
Unlike Lili Thapa's case (discussed above), the Court declined to declare Section 16 of the Constitution ultra vires to international law, but issued a directive to the Government to review the impugned Section 16 in the light of CEDAW, ICCPR and ICESCR. It may be noted that both the decisions in the Lili Thapa case and the Prakash Mani Sharma case were delivered by the same judges of the Supreme Court of Nepal.

\begin{abstract}
Abortion - Penalty higher for women than for men in cases of abortion is discriminatory, and therefore, men should be penalized on the same level as women are penalized
\end{abstract}

\title{
ADV. SAPANA PRADHAN MALLA AND OTHERS V. HIS MAJESTY'S GOVERNMENT, COUNCIL OF MINISTERS AND OTHERS
}

\section{Special Bench of the Supreme Court of Nepal on 25 February 2005 14 Supreme Court Bulletin 4}

In this case, the Supreme Court of Nepal found the existing system of penalty for men and for women in cases of abortion discriminatory and inconsistent with CEDAW, yet it did not order the Government to amend the discriminatory law by bringing down the penalty for women to the level of the penalty for men. Rather, it ordered the Government to penalize men at the higher level of penalty such as that which is given to women. In this way, the Court on the one hand validated the higher level of punishment and on the other denied the reproductive health rights of women.

Section 28 of the Chapter on "Homicide" in the National Code, 1963 provides that if a woman terminates her pregnancy on her own, she may be sentenced to up to five years of imprisonment subject to the period of maturity of the pregnancy. For example, if the pregnancy is of less than twenty-five weeks, she shall be imprisoned for up to three years, and if the pregnancy is of more than twenty-five weeks, she shall be imprisoned for up to five years. However, Sections 28 (A) and 32 of the same law provide up to three months' imprisonment for less than twenty five weeks' pregnancy and up to six months' imprisonment for pregnancy of more than twenty five weeks to any other persons (both men and women) who terminate pregnancy, except where it is terminated by the pregnant woman herself. Therefore, according to the writ petitioner, these provisions were discriminatory not only between men and women, but also among women.

The Court acknowledged that the provisions regarding the punishment of a pregnant woman charged with abortion, on the one hand, and other men and women accused of the same charge, on the other, seem different. However, the Court further said that those provisions were added only later by the eleventh amendment of the National Code. Therefore, they needed wider study, research, discussion, and deliberation before any conclusion could be reached about their impact on inequality between women and men, and on the state of unconstitutionality. In such a situation, the Court had to give proper consideration to the competency and wisdom of the legislature. 
A declaration of these provisions as unconstitutional and void as per the demand of the petitioner could therefore create a legal vacuum.

The writ petitioner had two major demands before the Court: first, to end the discrimination between men and women regarding the penalty for abortion; the second was to provide the reproductive health right to women by ending the system of penalty to women for abortion. The Court found the impugned provisions discriminatory yet declined to declare them null and void. On the contrary: the Court denied the reproductive health right of women and also validated the higher level of punishment by directing the Government to make the necessary amendments to the provisions that provide a lower level of punishment for men, in order to increase for men the level of punishment.

\section{Passport - Executive orders and decisions cannot contravene the Constitution and rules of international law to which Nepal is a party}

\section{PUNYAWATI PATHAK v. HIS MAJESTY'S GOVERNMENT, MINISTRY OF FOREIGN AFFAIRS AND OTHERS}

\section{Division Bench of the Supreme Court of Nepal on 25 November 2005}

The writ petitioners were two widowed women under 35 years of age. Before they approached the Supreme Court of Nepal, they had approached the District Administration Office (DAO), Kathmandu to obtain a passport. The DAO had, however, refused to register their application on the ground that His Majesty's Government had already on 25 December 1995 made a mandatory decision which required a woman below 35 years of age to submit a written affidavit from their guardians permitting them to obtain a passport. After being denied, the petitioners had approached the Supreme Court of Nepal asking it to declare the Cabinet decision null and void.

Under no circumstances did the Passport Act prohibit men and women from obtaining a passport except when they were under age (i.e., below sixteen years of age). However, the Passport Regulations, 2002 required for minor and mentally retarded persons an affidavit from their guardians. Neither the Act nor the Regulations prohibited any woman from obtaining a passport after coming of age.

The writ petitioners claimed that the decision of His Majesty's Government not only violated the equality clause of the Constitution of the Kingdom of Nepal, but had also curtailed their personal freedom and liberty, which violated Article 12(2) of the Constitution of the Kingdom of Nepal, 1990; Article 13(2) ${ }^{58}$ of the Universal Declaration of Human Rights, 1948, and different provisions of CEDAW. Therefore, the Court was requested to quash the decision of His Majesty's Government.

The Supreme Court, agreeing with the petitioners, said that Articles 11 and 12 of the 1990 Constitution, Passport Act, and Passport Regulations provide no authority

58 Art. 13(2) of the Universal Declaration of Human Rights, 1948 provides that "Everyone has the right to leave any country, including his own, and to return to his country." 
to the Government to impose any restrictions or to lay down conditions discriminatory between men and women regarding the issuance of passports. Therefore, the impugned decision of His Majesty's Government was clearly outwith the ambit of the executive power. The Court also noted that the decision of Government was an executive decision and not a law, but it had superseded the existing laws. Therefore, the Government had gone beyond its authority in curtailing the fundamental rights of citizens, and had also discriminated between men and women. The impugned decision had violated the equality clause of Article 11 and the rights to freedoms of Article 12 of the Constitution as well as the provisions of the International Covenant on Civil and Political Rights, 1966. Against this background, the Court quashed the discriminatory decision of the Government. Further, the Court also issued an order of mandamus to the opponents to provide every Nepali woman with a passport without the requirement of the approval of her guardian.

\section{Physical Punishment - Inhuman torture to child - Inconsistency with Constitu- tion and rules of international law}

\section{DEVENDRA ALE v. HIS MAJESTY'S GOVERNMENT, COUNCIL OF MINISTERS}

\section{Special Bench of the Supreme Court of Nepal on 15 December 2005}

The writ petitioner had challenged Section 7 of the Children Act, 1991 of Nepal that allowed parents, family members, guardians and school teachers to reprimand and mete out normal physical punishment to children as inconsistent with Article 14(4) of the Constitution of the Kingdom of Nepal, 1990; Article $7^{59}$ of the International Covenant on Civil and Political Rights, 1966, and Article $19^{60}$ of the Convention on the Rights of the Child, 1989 (CRC).

Article 14(4) of the Constitution of the Kingdom of Nepal, 1990 states that "No person ... shall be subjected to physical or mental torture, nor shall be given any cruel or inhuman or degrading treatment..." Section 7 of the Children Act, 1991 also protects children from torture. But the proviso to Section 7 of the Children Act provides that reprimand or normal physical punishment from their parents, family members, guardians or teachers to children shall not be considered as torture. The writ petitioner claimed that the impugned proviso would afford impunity to certain people who punish or torture children. The Human Development Report in South

\footnotetext{
59 Art. 7 of the International Covenant on Civil and Political Rights, 1966 provides, "No one shall be subjected to torture or to cruel, inhuman or degrading treatment or punishment. In particular, no one shall be subjected without his free consent to medical or scientific experimentation."

60 Art. 19 (1) of the UN Convention on the Rights of Child, 1989 provides, "States Parties shall take all appropriate legislative, administrative, social and educational measures to protect the child from all forms of physical or mental violence, injury or abuse, neglect or negligent treatment, maltreatment or exploitation, including sexual abuse, while in the care of parent(s), legal guardian(s) or any other person who has the care of the child."
} 
Asia, 1998 of the United Nations Development Program (UNDP) had found that 14 per cent of the school children in Nepal had dropped out of school due to fear of teachers. The National Report, 2002 submitted by Government of Nepal to the Child Rights Committee of the United Nations had also admitted the fact of the tendency of teachers to punish school children. Various countries including India and Pakistan had banned physical punishment at school; in Nepal, however, the respondents had made no efforts to control the torture or other inhuman treatment of school children. Against the backdrop of these facts, the petitioners had sought the Supreme Court to declare the impugned proviso null and void. Further, the petitioners had sought an order of mandamus or other necessary orders to make the Government take effective steps to control all kinds of torture and the inhuman and degrading treatment of school children.

The Supreme Court of Nepal emphasized that the Constitution of the Kingdom of Nepal, 1990 guarantees the right against torture as a fundamental right. Therefore, if any law was found inconsistent with that constitutional guarantee, the law could be declared void to the extent of that inconsistency. In addition, Section 9 of the Treaty Act, 1990 of Nepal provides that the Government give effect to the obligations of Nepal under international law by enacting necessary and appropriate laws. Further, Section 9 of the Treaty Act provides that in case of inconsistency between domestic laws and international treaties to which Nepal is a Party, the provisions of treaty law shall prevail over the domestic laws. Thus, in the context of the restriction on children's being subjected to any type of torture and inhuman or degrading practices under the CRC, the impugned proviso could not be found compatible with the Constitution and the Convention. Therefore, the Court found that the proviso to Section 7 of the Children Act, 1991 was inconsistent with Articles 14(4) and 25 (8) of the Constitution and Article 19 of the CRC.

\section{Racial Discrimination - Effective implementation of domestic law - Objectives of the Convention on Elimination of All Forms of Racial Discrimination}

\section{ADV. RATNA BAHADUR BAGCHAND AND OTHERS v. HIS MAJESTY'S GOVERNMENT, COUNCIL OF MINISTERS}

\section{Special Bench of the Supreme Court of Nepal on 21 April 2005}

The writ petitioner had asked the Supreme Court of Nepal to order the respondents to take necessary steps to make effective law and penalties for any act of racial discrimination, especially as regards untouchability, which is pervasively prevalent in Nepalese society. Although discrimination in respect of untouchability is prohibited and penalized by law, discrimination based on untouchability is widely rooted in Nepalese society. For example, Article $11(4)^{61}$ of the Constitution of the

${ }^{61}$ Art. 14(4) of the Constitution of the Kingdom of Nepal provides, "No person shall, on the basis of caste, be discriminated against as untouchable, be denied access to any public place, or be deprived of the use of public utilities. Any contravention of this provision shall be punishable by law." 
Kingdom of Nepal, 1990 prohibits all forms of discrimination including those based on untouchability and declares any such activities punishable by law. Further, Section 10(A) of the Chapter on "Social Values" in the National Code, 1963 penalizes untouchability. However, according to the writ petitioner, Section 10(A) did not give effect to the Constitutional provision since the Constitution mandates that "any contravention ... shall be punishable by law" whereas Section 10(A) stipulates that "...untouchability may be punishable". It was because of this "may" concept incorporated in Section 10(A) that the objectives of the "shall" concept of the Constitution and Articles $1,{ }^{62} 2^{63}$ and $4^{64}$ of the International Convention on Elimination of all Forms of Racial Discrimination (ICERD), 1966 to which Nepal was a Party had been defeated. As a consequence, there was not a single case of conviction under the impugned Section 10(A). Based on the provisions of the Constitution, and ICERD, the writ petitioner had asked the Supreme Court of Nepal to order the Government to make penalty for untouchability mandatory and effective.

The Supreme Court of Nepal observed that untouchability is a crime under Section 10(A) of the Chapter on "Social Values" in the National Code, 1963. Nevertheless, it gives discretionary power to the Court while penalizing the offender according to the seriousness of the crime. If the crime is serious, the Court can administer a higher penalty and when the crime is less serious, the Court can administer a lesser degree of penalty. It is because the nature of a crime is not always the same, thus it is wrong to award the same punishment to all offenders. This provision provides merely the flexibility to the Court to use judicial wisdom on the basis of the nature and seriousness of the crime. It does not provide to the Court any authority to provide immunity to an offender. The Court said that the petitioners had not mentioned any examples in the past of such immunity and impunity provided by the court. Therefore,

${ }^{62}$ Art. 1(1) of the International Convention on the Elimination of All forms of Racial Discrimination, 1966 provides, "In this Convention, the term 'racial discrimination' shall mean any distinction, exclusion, restriction or preference based on race, colour, descent, or national or ethnic origin which has the purpose or effect of nullifying or impairing the recognition, enjoyment or exercise, on an equal footing, of human rights and fundamental freedoms in the political, economic, social, cultural or any other field of public life."

${ }^{63}$ Id. Art. 2.1(d) provides, "States Parties condemn racial discrimination and undertake to pursue by all appropriate means and without delay a policy of eliminating racial discrimination in all its forms and promoting understanding among all races, and, to this end: (d) each State Party shall prohibit and bring to an end, by all appropriate means, including legislation as required by circumstances, racial discriminations by any persons, group or organization."

${ }^{64}$ Id. Art. 4(b) provides, "States Parties condemn all propaganda and all organizations which are based on ideas or theories of superiority of one race or group of persons of one colour or ethnic origin, or which attempt to justify or promote racial hatred and discrimination in any form, and undertake to adopt immediate and positive measures designed to eradicate all incitement to, or acts of, such discrimination and, to this end, with due regard to the principles embodied in the Universal Declaration of Human Rights and the rights expressly set forth in Article 5 of this Convention, inter alia: (b) shall declare illegal and prohibit organizations, and also organized and all other propaganda activities, which promote and incite racial discrimination, and shall recognize participation in such organizations or activities as an offence punishable by law." 
it was not logical and fair to term the impugned Section 10(A) erroneous on a subjective basis.

The Supreme Court further observed that discriminatory practices of untouchabilitiy cannot be controlled only by making a provision that would provide higher and stricter punishment to the offender. Nonetheless, to eliminate such practices, punishment is necessary. It is, nevertheless, equally necessary to develop a social mindset and opinion against untouchability and firmly establish the value in society that every individual is equal as a birthright. Therefore, untouchability is a concept wrongly and immorally practised in the Nepalese society, one that needs to be uprooted by society itself. The Court said that the degree of punishment is a policy matter of the Legislature and therefore the Court could not interfere in it. However, the Court issued a directive order to the Ministry of Law, Justice and Parliamentary Affairs, His Majesty's Government to make necessary laws and other arrangements consistent with Article 11(4) and Articles 1, 2 and 4 of the International Covenant on Elimination of all kinds of Racial Discrimination, 1965 after carrying out a study and consultation with key stakeholders including national-level civil society organizations.

\section{PHILIPPINES ${ }^{65}$}

\section{JUDICIAL DECISIONS}

Legality of service contracts with foreign companies involving national mineral resources - Obligations under bilateral investment agreements

LA BUGAL-B'LAAN TRIBAL ASSOCIATION, INC. et al. v. VICTOR RAMOS, SECRETARY, DEPARTMENT OF ENVIRONMENT AND NATURAL RESOURCES et al.

\section{[G.R. No. 127882. 27 January 2004]}

The Supreme Court struck down as unconstitutional certain portions of the Republic Act No. 7942 (otherwise known as the Philippine Mining Act of 1995) providing for Financial and Technical Assistance Agreements (FTAAs) between the Government and foreign-owned corporations. In this case, the Mining Act, its Implementing Rules and Regulations, and the FTAA between the Republic of the Philippines and WMC Philippines, Inc. (WMCP) were assailed by an association of ethnic and indigenous communities.

In holding that the Philippine Mining Act was invalid insofar as the said Act authorizes FTAAs, the Court declared that although the statute employs the phrase "financial and technical assistance agreements" in accordance with the 1987 Constitu-

${ }^{65}$ Contributed by Harry Roque Jr., Faculty Member, College of Law, University of Philippines, Diliman, Quezon City. 
tion, ${ }^{66}$ it actually treats these agreements as 'service contracts' that grant beneficial ownership to foreign contractors in contravention of the fundamental law. Private respondent WMCP, which is owned by WMC Resources International Pvt., Ltd., is a wholly owned subsidiary of Western Mining Corporation Holdings Limited, a publicly listed major Australian mining and exploration company. According to information provided by WMCP, it is a 100 per cent owned subsidiary of WMC Limited and is, therefore, disqualified from undertaking any "exploration, development, and utilization of natural resources" of Philippines.

Moreover, the Court found that the WMCP FTAA is indeed a service contract, as it grants WMCP "the exclusive right to explore, exploit, utilize, process and dispose of all mineral products and by-products that may be produced in the contract area." Its contractual stipulations, taken together, grant WMCP beneficial ownership over natural resources that properly belong to the state under the Constitution and are intended for the sole benefit of its citizens. Consequently, the Court struck down the WMCP FTAA.

In arguing against the annulment of the FTAA, WMCP invoked the Agreement on the Promotion and Protection of Investments between the Philippines and Australia, which was signed in Manila on 25 January 1995 and which entered into force on 8 December 1995. Article 3(1) of the Agreement provides that "[e]ach Party shall encourage and promote investments in its area by investors of the other Party and shall admit such investments in accordance with its Constitution, Laws, regulations and investment policies." The Agreement, in Article 3(2), also provides that "[e]ach Party shall ensure that investments are accorded fair and equitable treatment."

WMCP argued that under the said Agreement, Philippines could not rely upon the inadequacies of its own laws to deprive an Australian investor of fair and equitable treatment through the invalidation of WMCP's FTAA without similarly nullifying the other service contracts entered into before the enactment of the Mining Act. An invalidation of the FTAA would constitute a breach of Philippines' obligations under the Agreement, which would in turn amount to a violation of the generally accepted principle of pacta sunt servanda, which requires states to perform their treaty obligations in good faith.

The Court ruled against WMCP's assertion by declaring that assuming arguendo that WMCP was indeed correct in its interpretation of the treaty, the annulment of the FTAA would not constitute a breach of the treaty invoked. According to the Court, judicial decisions - including the decision herein invalidating the subject FTAA form part of the legal system of Philippines. The equal protection clause of the Constitution would then require that the decision apply to all contracts belonging

\footnotetext{
${ }^{66}$ Art. XII, § 2 reads: “...The President may enter into agreements with foreign-owned corporations involving either technical or financial assistance for large-scale exploration, development, and utilization of minerals, petroleum, and other mineral oils according to the general terms and conditions provided by law, based on real contributions to the economic growth and general welfare of the country. In such agreements, the State shall promote the development and use of local scientific and technical resources..."
} 
to the same class. The decision would then uphold, and not violate, the fair and equitable treatment stipulation contained in the agreement.

Effect of Treaty of Paris (ceding Spanish sovereignty over Philippines to the United States of America) on citizenship

MARIA JEANETTE C. TECSON and FELIX B. DESIDERIO, JR. v. The COMMISSION ON ELECTIONS, RONALD ALLAN KELLY POE (a.k.a. FERNANDO POE, JR.) and VICTORINO X. FORNIER

[G.R. No. 161434. 3 March 2004]

ZOILO ANTONIO VELEZ v. RONALD ALLAN KELLY POE (a.k.a. FERNANDO POE, JR.)

[G.R. No. 161634. 3 March 2004]

VICTORINO X. FORNIER v. HON. COMMISSION ON ELECTIONS and RONALD ALLAN KELLY POE (a.k.a. FERNANDO POE JR.)

\section{[G.R. No. 161824. 3 March 2004]}

In this case, the citizenship of Presidential candidate Ronald Allan Poe, also known as Fernando Poe, Jr., or FPJ, was questioned before the Supreme Court in several petitions. The petitioners alleged that FPJ made a material misrepresentation in his certificate of candidacy by claiming to be a natural-born Filipino citizen in spite of both his parents' being foreigners. They, therefore, argued that his certificate of candidacy should be denied due course or cancelled under Section 78 of the Omnibus Election Code, and that he be disqualified from the 2004 presidential elections.

In order to resolve the issue of Poe's citizenship, the Court looked into the history of the concept of citizenship under Philippine law.

On 10 December 1898, Spain and the United States entered into the Treaty of Paris. Article IX of the treaty provides:

Spanish subjects, natives of the Peninsula, residing in the territory over which Spain by the present treaty relinquishes or cedes her sovereignty may remain in such territory or may remove therefrom, retaining in either event all their rights of property, including the right to sell or dispose of such property or of its proceeds; and they shall also have a right to carry on their industry, commerce and professions, being subject in respect thereof to such laws as are applicable to foreigners. In case they remain in the territory they may preserve their allegiance to the crown of Spain by making, before a court of record, within a year from the date of the exchange of ratifications of this treaty, a declaration of their decision to preserve such allegiance; in default of which declaration 
they shall be held to have renounced it and to have adopted the nationality of the territory in which they reside.

The civil rights and political status of the native inhabitants of the territories hereby ceded to the United States shall be determined by the Congress.

According to the Court, the Treaty had the effect of depriving native inhabitants of Philippines of their status as Spanish subjects upon ratification of the treaty. Although they did not become American citizens, they, however, also ceased to be "aliens" under American laws and were issued passports describing them to be citizens of Philippines entitled to the protection of the United States.

The first comprehensive legislation by the US Congress on Philippines was the Philippine Bill of 1902, which was also referred to as the Philippine Organic Act of 1902. Under the Organic Act, a citizen of Philippines was one who was an inhabitant of Philippines, and a Spanish subject on the eleventh day of April, 1899.

In 1916, the Philippine Autonomy Act of the Jones Law virtually restated the provisions of the Philippine Bill of 1902. Under the former law, a native-born inhabitant of Philippines was deemed to be a citizen of Philippines as of 11 April 1899 if he was a subject of Spain on 11 April 1899, was residing in Philippines on the said date, and has since that date not become a citizen of another country.

The Supreme Court held that under the aforementioned laws, FPJ's paternal grandfather Lorenzo Pou must be deemed a Filipino citizen. As Pou's death certificate indicated that he died on 11 September 1954 at the age of 84 years in San Carlos, Pangasinan, it could, thus, be assumed that he was born sometime in the year 1870 when Philippines was still a colony of Spain. The Court also made use of the presumption that in the absence of evidence to the contrary; the place of residence of a person at the time of his death was also his residence before his death. Pou was, thus, a Filipino citizen, as he remained a Spanish subject on 11 April 1899, residing in Philippines on the said date, and since that date has not become a citizen of another country.

Pou consequently transmitted his Filipino citizenship to FPJ's father, Allan F. Poe. FPJ then is a Filipino citizen himself since, under the 1935 Constitution, which was in effect at the time FPJ was born, all persons whose fathers are Filipino citizens, regardless of whether such children are legitimate or illegitimate, are Filipino citizens. The Court disposed of the petitions by holding that FPJ therefore could not be deemed guilty of making a material misrepresentation in his certificate of candidacy. 


\section{Primacy of municipal law over international agreements - Protection of trade- marks and trade names}

MIGHTY CORPORATION and LA CAMPANA FABRICA DE TABACO, INC. v. E. \& J. GALLO WINERY and THE ANDRESONS GROUP, INC.

\section{[G.R. No. 154342. 14 July 2004]}

The Respondents Gallo Winery, a foreign Corporation not doing business in Philippines, and Andresons Group, Inc. - Gallo Winery's exclusive wine importer and distributor in the Philippines - sued the Petitioners Mighty Corporation and their sister company, Tobacco Industries, for damages, trademark infringement and unfair competition. The Respondents alleged that the Petitioners violated Article 6 of the Paris Convention for the Protection of Industrial Property and specific sections of Republic Act 166 (otherwise known as the Trademark Law) on trademark infringement, unfair competition and false designation of origin. They claimed that petitioners adopted the GALLO trademark to benefit from Gallo Winery's GALLO and ERNEST \& JULIA GALLO trademarks' established reputation and popularity, thus causing confusion, deception, and mistake on the part of the purchasing public.

Taking exception to the rulings of the Trial Court and the Court of Appeals, the Supreme Court held that the applicable laws were the Paris Convention and the Trademark Law, and not the Intellectual Property Code, as Respondents had filed the suit on 12 March 1993, at which time only the Convention and the Trademark Law were in effect. The Intellectual Property Code took effect only on 1 January 1998, about five years after the filing of the complaint.

The Paris Convention is an international agreement binding on the Philippines and the United States. Article 6 of the Convention prohibits "the registration or use of a trademark which constitutes a reproduction, imitation or translation, liable to create confusion, of a mark considered by the competent authority of the country of registration or use to be well-known in that country as being already the mark of a person entitled to the benefits of the Paris Convention and used for identical or similar goods." The Convention provides the following elements of trademark infringement:

a) registration or use by another person of a trademark which is a reproduction, imitation or translation liable to create confusion,

b) of a mark considered competent by the country of registration or well-known in that country as being already the mark of a person entitled to the benefits of the Paris Convention, and

c) such trademark is used for identical or similar goods.

The Supreme Court concluded that the Paris Convention protects well-known trademarks only (which are to be determined by domestic authorities), while the Trademark Law protects all trademarks, whether well known or not, provided that they are in actual commercial use in the Philippines. The Court declared that following universal 
acquiescence and comity, a municipal law would prevail in case of domestic legal disputes involving any conflicting provisions between an international agreement and a municipal law. Between the Paris Convention (an international agreement) and the Trademark law (a municipal law), therefore, the latter will prevail.

Furthermore, under both the Paris Convention and the Trademark Law, the protection of a registered trademark is limited only to goods identical or similar to those in respect of which such trademark is registered and only when there is likelihood of confusion. Under both, estoppel or laches may defeat the registrant's otherwise valid cause of action, and the time element in commencing infringement cases is material in ascertaining the registrant's express or implied consent to another's use of its trademark or a colourable imitation thereof.

The Court found that the actual commercial use of the GALLO wine trademark by the Respondents was subsequent to its registration in 1971 as well as to Tobacco Industries' commercial use of the GALLO cigarette trademark in 1973. It ruled that respondents never enjoyed the exclusive right to use the GALLO wine trademark to the prejudice of Tobacco Industries and its successors-in-interest, either under the Paris Convention or the Trademark Law.

It was also noted that the GALLO trademark registration certificates in the Philippines and in other countries expressly state that they cover wines only, without any evidence or indication that registrant Gallo Winery expanded or intended to expand its business to cigarettes. By strict application of Section 20 of the Trademark Law, therefore, Gallo Winery's exclusive right to use the GALLO trademark should be limited to wines, such being the only product indicated in its registration certificates.

The Court concluded that the Petitioners were not liable for trademark infringement, unfair competition or damages. The court also found no likelihood of confusion, mistake or deceit as to the identity or source of Petitioners' and Respondents' respective goods and businesses. The word "GALLO" was used as a family surname for the Gallo Winery's wines, while "GALLO" for Petitioners' cigarettes referred to the Spanish word for rooster. The various different features - such as colour schemes, art works and other markings - of both products also preclude any similarity between them. Lastly, wines and cigarettes do not belong to the same class of goods, nor are they identical or competing products. 


\section{Principle of equality under human rights - Existence of a positive obligation of states parties to eradicate discrimination}

CENTRAL BANK (now Bangko Sentral ng Pilipinas) EMPLOYEES ASSOCIATION, INC. v. BANGKO SENTRAL NG PILIPINAS and the EXECUTIVE SECRETARY

\section{[G.R. No. 148208. 15 December 2004]}

Almost eight years after the Republic Act No. $7653^{67}$ abolishing the old Central Bank of the Philippines and creating the new Bangko Sentral ng Pilipinas (BSP), the Petitioner Central Bank Employees Association, Inc., assailed the constitutionality of the last proviso in Section 15(c), Article II of which Act provides:

Section 15. Exercise of Authority - In the exercise of its authority, the Monetary Board shall:

(c) establish a human resource management system which shall govern the selection, hiring, appointment, transfer, promotion, or dismissal of all personnel. Such system shall aim to establish professionalism and excellence at all levels of the Bangko Sentral in accordance with sound principles of management.

A compensation structure, based on job evaluation studies and wage surveys and subject to the Board's approval, shall be instituted as an integral component of the Bangko Sentral's human resource development program: Provided, that the Monetary Board shall make its own system conform as closely as possible with the principles provided for under Republic Act No. 6758 [Salary Standardization Act]. Provided, however, that compensation and wage structure of employees whose positions fall under salary grade 19 and below shall be in accordance with the rates prescribed under Republic Act No. 6758.

The Petitioner alleged that the proviso establishes an unconstitutional classification of the employees of the BSP. The proviso divides BSP employees into two classes, namely: the BSP officers or those exempted from the coverage of the Salary Standardization Law (SSL); ${ }^{68}$ and the rank-and-file not exempted from the coverage of the SSL.

The proviso was assailed as not being based on substantial distinctions which make real differences, but solely on the salary grade of the BSP personnel's position. It was also questioned as not being germane to the purposes of Section 15(c), Article II of R.A. No. 7653, the most important of which is to establish professionalism and excellence at all levels in the BSP. The classification was, therefore, unreasonable, arbitrary, and in contravention of the equal protection clause of the Constitution.

The Supreme Court found that under present standards of equal protection the questioned proviso is valid. The exemption of certain officers from the SSL was intended to address the BSP's lack of competitiveness in terms of attracting competent

67 Republic Act No. 7653, The New Central Bank Act, 14 June 1993.

${ }^{68}$ Republic Act no. 6758, An Act prescribing a Revised Compensation and Position Classification System in the Government and for Other Purposes. 1 August 1989. 
officers and executives. It was not intended to discriminate against the rank-and-file. If the application of the proviso did in fact lead to a disparity of treatment between the officers and the rank-and-file in terms of salaries and benefits, the discrimination or distinction has a rational basis and is not arbitrary in the legislative sense. A statute valid at one time may, however, become void at another time because of altered circumstances.

The Court took judicial notice of the fact that after the enactment of the new BSP charter in 1993, Congress also undertook the amendment of the charters of the Government Service Insurance System (GSIS), the Land Bank of the Philippines (LBP), the development Bank of the Philippines (DBP) and the Social Security System (SSS), as well as those of other Government financial institutions (GFIs), from 1995 to 2004. The amended charters of the GSIS, LBP, DBP and SSS exempted all the personnel of the latter GFIs from the coverage of the SSL. The rank-and-file employees of seven other GFIs were granted the exemption that was specifically denied to their rank-and-file counterparts in the BSP. Within the class of rank-and-file personnel of GFIs, therefore, the BSP rank-and-file employees were discriminated against.

The Court concluded that the disparate treatment of the BSP rank-and-file employees from their counterparts in the other GFIs cannot stand judicial scrutiny, as no substantial distinctions exist between the two to justify denying the exemption to the BSP rank-and-file. Philippine legal history further shows that GFIs have long been recognized as comprising one distinct class, separate from other Governmental entities.

The Court also drew on the principle of equality under International Law, which has long been recognized and embodied in numerous regional and international instruments and conventions. ${ }^{69}$ Article 1 of the Universal Declaration of Human Rights $^{70}$ proclaims that all human beings are born free and equal in dignity and rights. Non-discrimination, together with equality before the law and equal protection of the law without any discrimination, constitutes basic principles in the protection of human rights.

The Court also noted that the equality provisions in these instruments do not merely function as traditional "first generation" rights commonly viewed as concerned

69 The decision cites the following international human rights instruments that contain general international provisions pertinent to discrimination and/or equality: the International Covenant on Civil and Political Rights (ICCPR); the International Covenant on Economic, Social and Cultural Rights (ICESCR); the International Convention on the Elimination of all Forms of Racial Discrimination (ICERD); the Convention on the Elimination of all Forms of Discrimination against Women (CEDAW); and the Convention on the Rights of the Child (CRC). The regional instruments looked into by the Court were the American Convention on Human Rights; the African Charter on Human and People's Rights; the European Convention on Human Rights; the European Social Charter of 1961 and revised Social Charter of 1996; and the European Union Charter of Rights and the Arab Charter on Human Rights of 1994.

${ }^{70}$ Universal Declaration of Human Rights Adopted and proclaimed by General Assembly resolution 217 A (III) of 10 December 1948. Available at: http://www.un.org/Overview/rights.html. Last visited 30 May 2006. 
only with constraining rather than requiring State action; rather, they impose a positive obligation on States parties to take steps to eradicate discrimination. Article 26 of the International Covenant on Civil and Political Rights requires "guarantee[s]" of "equal and effective protection against discrimination" while Articles 1 and 14 of the American and European Conventions oblige States Parties "to ensure ... the full and free exercise of [the rights guaranteed] ... without any discrimination" and to "secure without discrimination" the enjoyment of the rights guaranteed. With regard to employment, basic detailed minimum standards ensuring equality and prevention of discrimination are laid down in the International Covenant on Economic Social and Cultural Rights and in very large number of Conventions administered by the International Labour Organization, a United Nations body. Many other international and regional human rights instruments also have specific provisions relating to employment.

The Court held that a classification may be struck down if it has the purpose or effect of violating the right to equal protection and adopted the international law consensus on the principle that discrimination may occur indirectly, ${ }^{71}$ and pronounced that the two-tier analysis made in this case of the challenged provision, and its resulting conclusion of unconstitutionality by subsequent operation, are in consonance with the progressive trend of law in other jurisdictions and in international law.

\section{Treaty-making process - Ratification and signature - Duty of executive depart- ment to submit treaties to legislature for ratification}

SENATOR AQUILINO PIMENTEL, JR., et al. v. OFFICE OF THE EXECUTIVE SECRETARY represented by HON. ALBERTO ROMULO, and the DEPARTMENT OF FOREIGN AFFAIRS, represented by HON. BLAS OPLE

\section{[G.R. No. 158088, 6 July 2005]}

In this case, the Supreme Court resolved the question of whether the Executive Secretary and the Department of Foreign Affairs have a ministerial duty to transmit to the Senate the copy of the Rome Statute signed by a member of the Philippine Mission to the United Nations even without the signature of the President. The petition, which was filed by a Senator of the Philippines (Pimentel), a member of the House of Representatives, and a number of human rights advocacy groups and law students, was denied and the issue ruled in the negative.

\footnotetext{
71 The decision cites the Human Rights Committee's declaration, inspired by the definitions of discrimination adopted by the CERD and the CEDAW, that:

“... 'discrimination' as used in the [ICCPR] should be understood to imply any distinction, exclusion, restriction or preference which is based on any ground such as race, color, sex, language, religion, political or other opinion, national or social origin, property, birth or other status, and which has the purpose or effect of nullifying or impairing the recognition, enjoyment or exercise by all persons, on an equal footing, of all rights and freedoms."
} 
The Petitioners argued that the executive department was duty bound to transmit the signed copy of the Rome Statute to the Senate to allow it to exercise its discretion with respect to ratification of treaties. Invoking the Vienna Convention on the Law of Treaties, they also submit that Philippines has a ministerial duty to ratify the Rome Statute under treaty law and customary international law, and should refrain from acts which would defeat the object and purpose of signing the Rome Statute unless they have made their intention clear not to become a party to the treaty.

In interpreting Article 7, 221 of the 1987 Constitution, ${ }^{72}$ the Supreme Court held that contrary to the Petitioners' submission, ratification is a function of the President as the head of state and not of the Senate. Citing Executive Order No. 459 (EO 459) issued by President Fidel V. Ramos on 25 November 1997, the Court also pronounced guidelines for the negotiation and ratification of international agreements. EO 459 mandates that after the treaty has been signed by the Philippine representative, the same shall be transmitted to the Department of Foreign Affairs. The Department then prepares the ratification papers and forwards the signed copy of the treaty to the President for ratification. Only after the President has ratified the treaty does the Department submit the same to the Senate for concurrence. Upon receipt of the concurrence of the Senate, the Department of Foreign Affairs complies with the provisions of the treaty to render it effective.

The Court underscored the distinction between the signing of the treaty and the ratification as two separate and distinct steps in the treaty-making process. The signature, which is usually performed by the state's authorized representative in the diplomatic mission, is primarily intended as a means of authenticating the instrument and as a symbol of the good faith of the parties. Ratification, on the other hand, is the formal act by which a state confirms and accepts the provisions of a treaty concluded by its representative. It is generally held to be an executive act, undertaken by the head of the state or of the Government.

The Court ruled against the Petitioners' submission that Philippines is bound under treaty law and international law to ratify the treaty which it has signed. The signature neither binds the state nor signifies its final consent to the treaty. The President, being accountable to the people, has the responsibility and the duty carefully to study the contents of any treaty signed by the state's authorized representatives and ensure that it is not inimical to the interests of the state and its people. The President retains the discretion on whether or not to ratify the treaty even after its signing by the Philippine representative. The Court declared that the Vienna Convention on the Law of Treaties does not contemplate the defeat or even restraint of this power of the head of states, as to rule otherwise would be to render the requirement of ratification of treaties pointless and futile. The pronouncement that Philippines is under no legal obligation to ratify a treaty, however, was accompanied by the caveat that the refusal must be based on substantial grounds and not on superficial or whimsical reasons.

72 “... [N]o treaty or international agreement shall be valid and effective unless concurred in by at least two-thirds of all the Members of the Senate..." 


\title{
NATIONAL LAWS ON INTERNATIONAL LAW MATTERS
}

\section{Violence against Women and Children}

\begin{abstract}
An Act defining Violence against Women and their Children (VACW), providing for Protective Measures for Victims, prescribing Penalties thereof, and for Other Purposes
\end{abstract}

\section{Republic Act No. 9262}

Signed into law on 8 March 2004, Republic Act No. 9262 (also referred to as the Anti-VAWC law) addresses the realities of Philippine domestic life and recognizes the need to protect the family and its members, particularly women and children, from violence and threats to their personal safety and security. Under this Act, the Philippine Government binds itself to undertake efforts to address violence committed against women and children in keeping with the fundamental freedoms guaranteed under the Constitution and the provisions of the Universal Declaration of Human Rights, the Convention on the Elimination of All Forms of Discrimination Against Women, Convention on the Rights of the Child, and the various other international human rights instruments to which the Philippines is a party.

The Act criminalizes "violence against women and their children," which it defines as "any act or a series of acts committed by any person against a woman who is his wife, former wife, or against a woman with whom the person has or had a sexual or dating relationship, or with whom he has a common child, or against her child whether legitimate or illegitimate, within or without the family abode, which results in or is likely to result in physical, sexual, psychological harm or suffering, or economic abuse including threats of such acts, battery, assault, coercion, harassment or arbitrary deprivation of liberty."

Section 5 of the Act contains an extensive enumeration of the various acts through which violence against women and children is committed, namely:

(a) Causing physical harm to the woman or her child;

(b) Threatening to cause the woman or her child physical harm;

(c) Attempting to cause the woman or her child physical harm;

(d) Placing the woman or her child in fear of imminent physical harm;

(e) Attempting to compel or compelling the woman or her child to engage in conduct which the woman or her child has the right to desist from or to desist from conduct which the woman or her child has the right to engage in, or attempting to restrict or restricting the woman's or her child's freedom of movement or conduct by force or threat of force, physical or other harm or threat of physical or other harm, or intimidation directed against the woman or child. This shall include, but is not limited to, the following acts committed with the purpose or effect of controlling or restricting the woman's or her child's movement or conduct: 
(1) Threatening to deprive or actually depriving the woman or her child of custody or access to her/his family;

(2) Depriving or threatening to deprive the woman or her children of financial support legally due to her or her family, or deliberately providing the woman's children insufficient financial support;

(3) Depriving or threatening to deprive the woman or her child of a legal right;

(4) Preventing the woman from engaging in any legitimate profession, occupation, business or activity or controlling the victim's own money or properties, or solely controlling the conjugal or common money, or properties;

(f) Inflicting or threatening to inflict physical harm on oneself for the purpose of controlling her actions or decisions;

(g) Causing or attempting to cause the woman or her child to engage in any sexual activity which does not constitute rape, by force or threat of force, physical harm, or through intimidation directed against the woman or her child or her/his immediate family;

(h) Engaging in purposeful, knowing, or reckless conduct, personally or through another that alarms or causes substantial emotional or psychological distress to the woman or her child. This shall include, but not be limited to, the following acts:

(1) Stalking or following the woman or her child in public or private places;

(2) Peering in the window or lingering outside the residence of the woman or her child;

(3) Entering or remaining in the dwelling or on the property of the woman or her child against her/his will;

(4) Destroying the property and personal belongings or inflicting harm to animals

or pets of the woman or her child; and

(5) Engaging in any form of harassment or violence;

(i) Causing mental or emotional anguish, public ridicule or humiliation to the woman or her child, including, but not limited to, repeated verbal and emotional abuse, and denial of financial support or custody of minor children or denial of access to the woman's child/children.

The Anti-VAWC Law also covers a wide range of offensive acts that have historically been committed against women and children, but have evaded effective prosecution and punishment. Among its provisions include definitions of physical, sexual, and psychological violence, battery, as well as economic abuse and deprivation, and a recognition of battered women's syndrome "scientifically defined pattern of psychological and behavioural symptoms found in women living in battering relationships" as a defence. Its protection extends not only to women in relationships formalized by marriage, but also to those in "dating relationships".

The Anti-VAWC law also provides for the issuance of protection orders, which may be filed by the offended parties, their relatives, as well as concerned public and social welfare officers, and enforced by law enforcement agencies, for the purpose of preventing further acts of violence against women and their children who have become victims of the criminalized acts. The protection order also provides for other necessary measures which serve the purpose of safeguarding the victim from further 
harm, of minimizing any disruption in the victim's daily life, and facilitating the opportunity and ability of the victim independently to regain control over her life.

The law also empowers the various local law enforcement and social welfare authorities to deal with instances of violence against women and children, and provides for comprehensive training, information, education programmes, and other institutional assistance and support programmes.

\section{Quarantine and International Health Surveillance}

\section{An Act Strengthening the Regulatory Capacity of the Department of Health in Quarantine and International Health Surveillance Repealing for the Purpose Republic Act No. 123 of 1947, As Amended Republic Act No. 9271}

The Quarantine Act of 2004, signed on 19 March 2004, grants the Bureau of Quarantine under the Department of Health (DOH), a nationwide scope of function and international commitment in accord with the International Health Regulations (IHR) of the World Health Organization (WHO). The Act imposes upon the Bureau the responsibility for conducting examinations of incoming and outgoing vessels and aircraft, their cargoes, passengers, crews, and all personal effects, and the issuance of quarantine certificates, bills of health or other equivalent documents at ports of entry and exit in Philippines, as well as for conducting the necessary surveillance over their sanitary conditions. The Bureau also has authority over both domestic and foreign incoming and outgoing vessels and, including those of the army and navy, their anchorage, and over aircraft and airports, insofar as necessary for the proper enforcement of the provisions of the Act.

The Act emerged as a response to various international epidemics that affected a number of Southeast Asian states, and grants the bureau broad powers to prevent the introduction, transmission or spread of "public health emergencies of international concern" from foreign countries into the Philippines or from one of its domestic seaports and airports to another.

The law authorizes the authorities to undertake necessary intervention strategies, such as health education and advisories, inspections, fumigation, disinfection, pest extermination, vaccination for international travel, medical examination of aliens/ foreigners for immigration purposes, and the destruction of animals or articles found to be infected or contaminated as sources of infection to human beings in coordination with other concerned quarantine agencies, such as veterinary and plant quarantine, and other measures as adjudged to be necessary.

Some of the law's core prevention measures include the imposition of mandatory immunization and preventive treatment for all persons arriving at Philippine ports of entry, and the isolation of persons examined to have been infected or exposed to infection aboard vessels or in hospitals and quarantine stations. The law also authorizes the Director of the Bureau, in cooperation with the Bureau of Customs, to prohibit the entry of cargo into the Philippines in the event of any public health 
emergency of international concern in a foreign country where there is imminent danger of the introduction of hazardous cargoes or materials into the Philippines.

\section{An Act to Institutionalize the Use of an Alternative Dispute Resolution System in the Philippines and to Establish the Office for Alternative Dispute Resolution, and for Other Purposes}

\section{Republic Act No. 9285}

Signed into law on 2 April 2004, the Alternative Dispute Resolution Act of 2004 binds the Philippine Government to actively promote the freedom of parties to a dispute to make their own arrangements and resolve their disputes. The Act encourages and actively promotes the use of Alternative Dispute Resolution (ADR) as an alternative procedure for the resolution of appropriate cases and an important means to achieve speedy and impartial justice and to reduce court dockets. That private sector participation plays an active role in the settlement of disputes through ADR is recognized in the Act, which is without prejudice to the introduction by the Supreme Court of any ADR system, such as mediation, conciliation, arbitration, in the near future.

The Act imposes strict principles and guidelines of confidentiality on the handling of information obtained from mediation proceedings which it outlines in Section 9:

(a) Information obtained through mediation shall be privileged and confidential.

(b) A party, a mediator, or a non-party participant may refuse to disclose and may prevent any other person from disclosing a mediation communication.

(c) Confidential information shall not be subject to discovery and shall be inadmissible in any adversarial proceeding, whether judicial or quasi-judicial. However, evidence or information that is otherwise admissible or subject to discovery does not become inadmissible or protected from discovery solely by reason of its use in mediation.

(d) In such an adversarial proceeding, the following persons involved or previously involved in a mediation may not be compelled to disclose confidential information obtained during the mediation: (1) the parties to the dispute; (2) the mediator or mediators; (3) the counsel for the parties; (4) the non-party participants, (5) any persons hired or engaged in connection with the mediation as secretary, stenographer, clerk, or assistant; and (6) any other person who obtains or possesses confidential information by reason of his/her profession.

(e) The protections of this Act shall continue to apply even if a mediator is found to have failed to act impartially.

(f) A mediator may not be called to testify to provide information gathered in mediation. A mediator who is wrongfully subpoenaed shall be reimbursed the full cost of his/her attorney's fees and related expenses. 
Chapter 4 of the Act on International Commercial Arbitration defines commercial arbitration as arbitration covering matters arising from all relationships of a commercial nature, whether contractual or not. ${ }^{73}$ It also adopts the Model Law on International Commercial Arbitration adopted by the United Nations Commission on International Trade $\mathrm{Law}^{74}$ to govern international commercial arbitration in the country. Significantly, the Act provides for the interpretation of the Model Law by stating that resort be made to the travaux preparatories and the report of the Secretary General of the United Nations Commission on International Trade Law. ${ }^{75}$

Chapter 5 of the Act deals with Domestic Arbitration and Republic Act No. $876,{ }^{76}$ otherwise known as "The Arbitration Law" as the governing law applicable to all domestic arbitrations - arbitrations not considered international in the sense of Article 1(3) of the Model Law.

The Act similarly provides that the Arbitration of Construction Disputes shall continue to be governed by Executive Order No. $1008,{ }^{77}$ otherwise known as the Construction Industry Arbitration Law. The Construction Industry Arbitration Commission (the "Commission") created by the said Executive Order shall continue to exercise its original and exclusive jurisdiction over arbitrations of construction disputes in spite of the arbitration being "commercial" pursuant to Section 21 of the Act. The construction disputes which also fall within the original and exclusive jurisdiction of the Commission include those between or among parties to, or who are otherwise bound by, an arbitration agreement, directly or by reference whether such parties are project owner, contractor, subcontractor, fabricator, project manager, design professional, consultant, quantity surveyor, bondsman or issuer of an insurance policy in a construction project. ${ }^{78}$ The Commission shall continue to exercise original and exclusive jurisdiction.

\footnotetext{
${ }^{73}$ Under $\$ 21$ of the Act, relationships of a commercial nature include, but are not limited to, the following transactions: any trade transaction for the supply or exchange of goods or services; distribution agreements; construction of works; commercial representation or agency; factoring; leasing; consulting; engineering; licensing; investment; financing; banking; insurance; joint venture and other forms of industrial or business cooperation; carriage of goods or passengers by air, sea, rail or road.

${ }^{74}$ Adopted on 21 June 1985 (United Nations Document A/40/17), the Model Law was also recommended for enactment by the General Assembly in Resolution No. 40/72 (approved on 11 December 1985).

75 "International Commercial Arbitration: Analytical Commentary on Draft Text." Ref. No.a/CN. 9/264, 25 March 1985.

76 "An Act To Authorize The Making Of Arbitration And Submission Agreements, To Provide For The Appointment Of Arbitrators And The Procedure For Arbitration In Civil Controversies, And For Other Purposes," 19 June 1953.

77 "Creating An Arbitration Machinery In The Construction Industry Of The Philippines," 4 February 1985.

${ }^{78}$ Chapter 6, § 35 .
} 


\section{OTHER RELEVANT STATE PRACTICE}

\section{Opinion of the Secretary of Justice}

Opinion no. 045, s. 2004, 5 May 2004, "On whether the records custodians of the Philippine telecommunications entities should comply with the subpoenas duces tecum issued by the United States District Court of Hawaii, requiring such records custodians to appear and bring with them documents and records, in connection with the Grand Jury proceedings in Honolulu, Hawaii, initiated by the US Department of Justice for alleged violations of the US Antitrust Laws."

Commissioner Ronald Olivar Solis of the National Telecommunications Commission requested advice on the issue of whether the records custodians of Philippine telecommunications entities should comply with the subpoena duces tecum issued by the United States District Court of Hawaii, in connection with Grand Jury proceedings for alleged violations of US Anti-Trust Laws.

Acting Justice Secretary Ma. Merciditas Gutierrez stated that the RP-US Mutual Legal Assistance Treaty (MLAT) in Criminal Matters remains in force. The Treaty obligates the contracting parties to provide mutual assistance, in accordance with the provisions of the treaty, in connection with the prevention, investigation and prosecution of criminal offences, and in proceedings related to criminal matters. It provides that assistance shall include, inter alia, providing documents, records and items of evidence.

It was noted that the principal incentive for many Governments to negotiate MLATs with the United States was the desire to curtail US prosecutors, police agents, and courts from having to resort to unilateral and extraterritorial means of collecting evidence from abroad. This incentive would be rendered useless if procurement of evidence through a subpoena duces tecum would be allowed.

The Secretary concluded that the procurement of documents, records and pieces of evidence should, therefore, be done through the existing MLAT, subject to the conditions and limitations spelled out in Article 39 thereof - which require due consideration and the application of pertinent provisions of our Constitution and existing municipal laws such as Presidential Decree no. $1718 .^{79}$ 


\section{Mutual Legal Assistance in Criminal Matters}

\section{RP-Hong Kong Agreement Concerning Mutual Legal Assistance in Criminal Matters}

Philippine Senate Resolution No. 342

\section{February 2004}

The Philippine Senate expressed its concurrence with the RP-HONG KONG Agreement on Mutual Assistance on Legal and Criminal Matters, signed in 2001, in a 2004 Senate Resolution. The treaty, which governs matters of judicial cooperation between the two parties, covers a wide range of matters including the service of documents, the obtaining of evidence, the conduct of searches and seizures and the effecting of witness testimonies. It excludes extradition, however, and merely allows cooperation between the two countries in the tasks of "identifying and locating persons" and "effecting the temporary transfer of persons in custody to appear as witnesses".

The Agreement carries safeguards such as the political offence exception (Article IV, Limitations on Compliance, paragraphs 1.b, 1.c, and 1.d) and the double criminality requirement (id., paragraph $1 . \mathrm{g}$ ). It also expressly designates the Department of Justice as the executing authority in Philippines.

Negotiated by both parties from as early as 1998, the agreement allows the two Governments to cooperate and provide mutual assistance in the investigation and prosecution of criminal offences and in proceedings related to criminal matters.

The Governments of the two countries pledge to help each other in identifying and locating persons, serving documents, obtaining evidence, articles or documents, executing requests for search and seizure, and facilitating the appearance of witnesses. The agreement also enables the two parties to effect the temporary transfer of persons in custody to appear as witnesses; to obtain judicial or official records; to trace, restrain, forfeit and confiscate the proceeds and instruments of criminal activities; to recover pecuniary penalties for offences; and to deliver property as well as provide information, documents and records.

\section{Extradition}

\section{RP-China Extradition Treaty Philippine Senate Resolution No. 343}

\section{February 2004}

The Senate expressed its concurrence with the new extradition treaty the Philippines signed with the People's Republic of China in 2001. The treaty enshrines 
the double criminality principle - which requires offences to be "punishable under the laws of both parties" for them to be extraditable - under Article 2, paragraph 1. The article similarly carries a list of the crimes for which a person can be extradited.

Article 4 of the treaty, however, acknowledges the political offence exception, which prevents a state from using extradition as a weapon to bring back political rebels and dissenters within its coercive power. The treaty also incorporates a Rule of Specialty under Article 16. Under this article, a person extradited by the Philippines to China for a specified offence can be tried by China only for that offence and for no other. This rule ensures that the requesting state will not be able to defeat the "political offence exception" by requesting extradition for a common crime, and subsequently turning around and charging the extraditee for a different offence.

The treaty also provides for the non-extradition of a party's own nationals under Article 3, paragraph 1, and includes a surrender provision obligating the two parties to arrest and surrender fugitives from the requesting state.

\section{Organic Pollutants}

\section{Stockholm Convention on Persistent Organic Pollutants Philippine Senate Resolution No. 676}

\section{February 2004}

The Stockholm Convention on persistent organic pollutants (POPs) forms a framework - based on the precautionary principle ${ }^{80}$ - which seeks to guarantee the safe reduction and elimination of the production and use of POPs. The Convention initially covers twelve priority POPs, formed intentionally or unintentionally through industry and waste combustion, with the intent to cover other substances in the long run as well. It defines the substances in question, while leaving open the possibility of adding new ones, and also defines the rules governing the production, importing and exporting of those substances.

The twelve priority POPs covered by the Convention are aldrin, chlordane, dichlorodiphenyltrichlorethane (DDT), dieldrin, endrin, heptachlor, mirex, toxaphene, polychlorobiphenyls (PCBs), hexachlorobenzene, dioxins and furanes.

Initially, the Convention aims at prohibiting the production and use of nine POPs and minimizing the production and use of a tenth substance. In the case of the last

\footnotetext{
${ }^{80}$ The precautionary principle states that "Where there are threats of serious or irreversible damage, lack of full scientific certaintyshall not be used as a reason for postponing cost-effective measures to prevent environmental degradation." Preamble to the Rio Declaration on Environment and Development, U.N. Conference on Environment and Development, Princs. 15, 7, 3, U.N. Doc. A/ Conf.151/26/Rev.1 (Vol.1) (1992), available at <http:// www.unep.org/Documents/Default.asp? DocumentID=78\&ArticleID=1163>.
} 
two POPs, the objective is to minimize the occurrences of their unintentional production and release into the environment. The rules laid down in the Convention do not apply to quantities of a chemical to be used for laboratory-scale research. The Convention also allows for certain exemptions from the provisions on the elimination or minimization of production or use of these substances and, consequently, from the rules on imports and exports. Such exemptions are specific to each POP and are defined, case by case, in the Annexes to the Convention.

The Convention provides for ending imports and exports of banned POPs. However, chemicals classified as POPs may be imported for environmentally sound disposal of existing POPs (destruction of waste, etc.) or in the case of a grant of an exemption authorizing production and use of the substances in question. Exports are similarly authorized for the environmentally sound disposal of existing POPs (destruction of waste, etc.), in the case of a grant of an exemption authorizing production and use of the substances in question, and in exports to States which have not signed the Convention but provide annual certification to the exporting party in expressing compliance with the objectives of the Convention.

The Parties to the Convention are also required to develop a national, regional or sub-regional action plan for implementing the Convention which they must submit to the Conference of parties, the principal body assigned the task of implementing the Convention. The plan must include an evaluation of releases and an evaluation of the efficacy of the existing laws and policies on management of such releases, as well as strategies for meeting the objectives of the Convention. The Convention includes general guidelines on best available techniques and best environmental practices for preventing or minimizing releases, and provides for measures to reduce or eliminate releases containing POPs from stockpiles and wastes.

The Convention was adopted by 150 Governments during a conference held in Stockholm from 22 to 23 May 2001. The Convention entered into force soon after the Philippine Senate's concurrence on 17 May 2004.

\section{Mutual Legal Assistance in Criminal Matters}

\section{RP-Swiss Confederation Treaty on Mutual Legal Assistance in Criminal Matters Philippine Senate Resolution No. 743}

\section{February 2004}

The Senate concurred with a Treaty on Mutual Legal Assistance in Criminal Matters between the Philippines and the Swiss Confederation signed on 9 July 2002, similar to that entered into with Hong Kong SAR. 


\section{Other Agreements Concurred by the Philippine Senate in 2004}

The Philippine Senate has also concurred with various health and agriculturalrelated agreements in 2004, namely: the Agreement Between the Philippines and the International Plant Generic Resources Institute Acting in Administration of the International Network for the Improvement of Banana and Plantain (INIBAP) Relating to the INIBAP Office for Asia and the Pacific, ${ }^{81}$ the Agreement on the Establishment of the International Vaccine Institute, ${ }^{82}$ and the Agreement on the Establishment of the International Network for Bamboo and Rattan. ${ }^{83}$

\section{Tobacco Control}

\section{Framework Convention on Tobacco Control (FCTC) ${ }^{84}$ Philippine Senate Resolution No. 195}

\section{April 2005}

The Philippine Senate expressed its concurrence with the WHO Framework Convention on Tobacco Control (WHO FCTC), the first treaty negotiated under the auspices of the World Health Organization. The WHO FCTC has been widely hailed as marking a paradigm shift in developing a regulatory strategy to address addictive substances. In contrast to previous drug control treaties, the WHO FCTC now asserts the importance of demand reduction strategies as well as supply issues.

The WHO FCTC developed as a response to the globalization of the tobacco epidemic, which was facilitated through a variety of complex factors with cross-border effects, including trade liberalization, direct foreign investment, global marketing, transnational tobacco advertising, promotion and sponsorship, and the international movement of contraband and counterfeit cigarettes.

The Convention employs both price and tax related mechanisms, as well as nonprice measures, to reduce the supply and demand of tobacco in national markets. The non-price measures imposed by the Convention ${ }^{85}$ to reduce the demand for tobacco include measures to ensure protection from exposure to tobacco smoke; regulation of the contents of tobacco products; regulation of tobacco product disclosures; packaging and labelling of tobacco products; education, communication, training and public awareness; tobacco advertising, promotion and sponsorship; and demand-reduction measures concerning tobacco dependence and cessation. The core

\footnotetext{
81 P.S. Res. No. 739 - 2 February 2004.

82 P.S. Res. No. 740 - 2 February 2004.

83 P.S. Res. No. 741 - 2 February 2004.

84 Available at: http://www.who.int/tobacco/framework/WHO_FCTC_english.pdf. Last visited 30 May 2006.

85 Arts. 6 to 14 .
} 
supply reduction measures include regulations against illicit trade in tobacco products and sales to and by minors and provision of support for economically viable alternative activities.

The Convention includes provisions that address liability and outline mechanisms for scientific and technical cooperation and information exchange. ${ }^{86}$

\section{Conservation and Management of Highly Migratory Fish Stocks}

\section{Convention on the Conservation and Management of Highly Migratory Fish Stocks in the Western and Central Pacific Ocean ${ }^{87}$ Philippine Senate Resolution No. 242}

\section{May 2005}

After four years of complex negotiations between the coastal States of the Western and Central Pacific and other States fishing in that region, the Convention on the Conservation and Management of Highly Migratory Fish Stocks in the Western and Central Pacific Ocean was opened for signature in Honolulu on 5 September 2000. The Convention is one of the first regional fisheries agreements to be adopted since the conclusion of the UN Fish Stocks Agreement in 1995. The Philippines, which was among the states that participated in the Multilateral High-Level Conference on the Conservation and Management of Highly Migratory Fish Stocks in the Western and Central Pacific, expressed its concurrence with the Convention in 2005.

The Convention aims to ensure, through effective management, the long-term conservation and sustainable use of highly migratory fish stocks in the western and central Pacific Ocean in accordance with the 1982 United Nations Convention on the Law of the Sea and the 1995 UN Fish Stocks Agreement. For this purpose, the Convention establishes a Commission for the Conservation and Management of Highly Migratory Fish Stocks in the Western and Central Pacific Ocean - with the Contracting Parties being designated as ipso facto members of the Commission. In accordance with the provisions of Article 36, the Convention entered into force on 19 June 2004, six months after the deposit of the thirteenth instrument of ratification, acceptance, approval or accession.

Convention applies to all species of highly migratory fish stocks (all fish stocks of the species listed in Annex I of the 1982 Convention occurring in the Convention Area $^{88}$ and such other species of fish as the Commission may determine), with the

\footnotetext{
86 Arts. 20 to 22 .

87 Available at http://www.oceanlaw.net/texts/westpac.htm. Last visited 30 May 2006.

88 The Convention Area, as defined in article 3 of the Convention, comprises all waters of the Pacific Ocean bounded to the south and to the east by a line drawn from the south coast of Australia due south along the $141^{\circ}$ meridian of east longitude to its intersection with the $55^{\circ}$ parallel of south latitude; thence due east along the $55^{\circ}$ parallel of south latitude to its intersection with the $150^{\circ}$ meridian of east longitude; thence due south along the $150^{\circ}$ meridian of east longitude to its
} 
exception of sauries, within the Convention area. The conservation and management measures under the Convention are to be applied throughout the range of the stocks, or to specific areas within the Convention Area, as determined by the Commission.

The Convention remains open for accession ${ }^{89}$ by the States referred to in Article 34, paragraph 1, and by any entity referred to in Article 305, Paragraph 1(c), (d) and (e) of the United Nations Convention on the Law of the Sea situated in the Convention Area. The Contracting Parties may also, by consensus, invite other States and regional economic integration organizations whose nationals and fishing vessels wish to conduct fishing for highly migratory fish stocks within the Convention Area to accede to the Convention.

\section{Forced or Compulsory Labour}

\section{ILO Convention Concerning Forced or Compulsory Labour (Forced Labour Convention) $)^{90}$ \\ Philippine Senate Resolution No. 195}

\section{May 2005}

The Forced Labour Convention, 1930 (N. 29) requires the suppression of forced or compulsory labour in all its forms. The Convention defines forced labour as "all work or service which is exacted from any person under the menace of any penalty and for which the said person has not offered himself voluntarily". "Forced labour", however, does not include such obligations as military service; work or service which is part of normal civic obligations; work or service exacted as a consequence of a conviction in a court of law, under certain conditions; work exacted in cases of emergencies such as wars, fires, earthquakes, etc.; and minor communal services as defined. The Convention requires the Contracting Parties to impose and strictly enforce "really adequate" penal sanctions in cases of illegal exaction of forced or compulsory labour that take place within their territories. ${ }^{91}$

Countries that have ratified the Forced Labour Convention undertake "to suppress the use of forced or compulsory labour in all its forms within the shortest possible period". ${ }^{92}$ The Convention has been the most widely ratified of all the Fundamental ILO Conventions, since it was adopted in Geneva on 28 June 1930. It entered into

\footnotetext{
intersection with the $60^{\circ}$ parallel of south latitude; thence due east along the $60^{\circ}$ parallel of south latitude to its intersection with the $130^{\circ}$ meridian of west longitude; thence due north along the $130^{\circ}$ meridian of west longitude to its intersection with the $4^{\circ}$ parallel of south latitude; thence due west along the $4^{\circ}$ parallel of south latitude to its intersection with the $150^{\circ}$ meridian of west longitude; thence due north along the $150^{\circ}$ meridian of west longitude.

${ }^{89}$ In accordance with paragraph 1 of Article 35,

90 Available at http://www1.umn.edu/humanrts/instree/n0ilo29.htm. Last visited 30 May 2006.

91 Id.

${ }^{92} I d$.
} 
force generally on 1 May 1932, and entered into force within Philippines on 15 July 2005, upon registration of its ratification with the International Labour Office. Out of the 178 ILO Member States, Philippines became the 168th Member State to have ratified the instrument as of 2005.

\section{SRI LANKA ${ }^{93}$}

\section{JUDICIAL DECISIONS}

Fundamental Rights - Death of détenue in Police custody in consequence of alleged torture - Acquired right to enforcement - Locus standi of the widow to prosecute such right - Time bar - Interpretation of statutes

SRIYANI SILVA (WIFE OF JAGATH KUMARA-DECEASED) v. IDDALMAGODA, OFFICER-IN-CHARGE, POLICE STATION, PAYAGALA AND OTHERS

\section{Supreme Court, 10 December 2002}

S N Silva, CJ., Bandaranayake, J. and Edussuriya, J. [2003] 1 Sri Lanka Law Reports 14

This case was an application filed by the wife of a deceased detainee pleading for a declaration that her husband's fundamental rights guaranteed under Articles $11,,^{94} 13(1)^{95}$ and $13(2)^{96}$ of the Constitution had been violated. The question before the Court was "whether the wife or a third party of a deceased person has a right to institute proceedings in this Court in terms of the provisions of the Constitution, seeking relief for the alleged infringement of a deceased person's fundamental rights."

The Respondents argued that under the provisions of the Constitution, ${ }^{97}$ only a person whose rights have been infringed can make an application to vindicate those rights. "Therefore a relative of a person, whose death was caused by torture, would to be able to obtain redress through the fundamental rights jurisdiction enshrined

${ }^{93}$ Contributed by Camena Guneratne, Senior Lecturer, Department of Legal Studies, Open University of Sri Lanka.

${ }^{94}$ No person shall be subjected to torture or to cruel, inhuman or degrading treatment or punishment.

95 "No person shall be arrested except according to procedure established by law. Any person arrested shall be informed of the reason for his arrest."

96 "Every person held in custody, detained or otherwise deprived of personal liberty shall be brought before the judge of the nearest competent court according to procedure established bylaw, and shall not be further held in custody, detained or deprived of personal liberty except upon and in terms of the order of such judge made in accordance with procedure established by law."

97 The relevant provision is Article 126 (2) of the Constitution which reads "Where any person alleges that any such fundamental right or language right relating to such person has been infringed 
in our Constitution." The Court, by a majority of two to one rejected this argument based on the principle "there is no right without a remedy." Bandaranayake, J., pointed out that the Constitution guaranteed a person, inter alia, protection from torture, and from arbitrary arrest and detention. Consequently, the deceased detainee who was arrested, detained and allegedly tortured and who subsequently died had acquired a right to seek redress from the Court for the alleged violation of his rights. She went on to say

\begin{abstract}
It could never be contended that the right ceased and would become ineffective due to the intervention of the death of the person, especially in circumstances where the death is itself the consequence of injuries that constitute the infringement. If such an interpretation is not given it would result in a preposterous situation in which a person who is tortured and survives could vindicate his rights in proceedings before this Court, but if the torture is so intensive that it results in death, the rights cannot be [so vindicated]. In my view a strict literal construction should not be resorted to where it produces such an absurd result. ... Hence, when there is causal link between the death of a person and the process, which constitutes the infringement of such person's fundamental rights, anyone having a legitimate interest could prosecute that right in a proceeding instituted in terms of Article 126(2) of the Constitution.
\end{abstract}

However, in a dissenting judgement, Edussuriya J., while referring to the International Convention on Torture, held that it could not have retrospective application in Sri Lanka. He stated that Article 126(2) is unambiguous and does not permit anyone other than the person whose rights have been infringed from seeking redress. $\mathrm{He}$ noted that Counsel for the Petitioner had drawn the attention of the Court to the fact that Sri Lanka had ratified the International Convention Against Torture and Other Cruel, Inhuman and Degrading Treatment or Punishment and is obliged to grant redress to victims of torture, and had argued that in the event of the death of such a victim the dependants are entitled to compensation, and Article 126 should be construed accordingly.

Edussuriya, J. took the view that the Convention had been ratified in 1994, while the Constitution had been promulgated in 1978. He stated "[i]t certainly cannot be said that one can read into Article 126(2) of the Constitution of 1978 a legislative intention in 1978 to grant relief to a widow of a person whose fundamental rights have been infringed because Sri Lanka ratified the International Convention Against Torture sixteen years later in 1994, containing a provision to grant relief to dependants of victims of torture in the event of the death of the victim as a result of torture." 98

\footnotetext{
or is about to be infringed by executive or administrative action, he may himself or by an attorney-atlaw on his behalf, within one month thereof, in accordance with such rules of court as may be in force, apply to the Supreme Court by way of petition in writing addressed to such Court praying for relief or redress in respect of such infringement. Such application may be proceeded with only [when] leave to proceed first had [been] obtained from the Supreme Court, which leave may be granted or refused, as the case may be by not less than two Judges."
} 


\title{
Right to Housing - International Covenant of Economic, Social and Cultural Rights
}

INTER-RELIGIOUS PEACE FOUNDATION AND CENTRE FOR SOCIETY AND RELIGION v. DIRECTOR GENERAL, URBAN DEVELOPMENT AUTHORITY AND OFFICER-IN-CHARGE, POLICE STATION WATTALA

\author{
Human Rights Commission of Sri Lanka \\ 23 February 2004 \\ HRC/803/01/7(i)
}

The Petitioners in this case were a group of people occupying small houses or tenements given to them or to their predecessor in title by the then Member of Parliament for the Wattala area. ${ }^{99}$ They claimed that the Member of Parliament gave them an assurance that their ownership would be regularised in due course. However, they further claimed that at the present time, due to political reasons, they faced eviction from the land. The petition was based on three grounds: that the relevant procedure laid down in the law ${ }^{100}$ had not been followed; that they had rights to the land under the doctrine of legitimate expectation, and that the principles of natural justice had been violated in that they had not been given an opportunity to be heard.

While the Commission addressed these issues under Sri Lankan law, it also referred to Sri Lanka's obligations under the International Covenant on Economic, Social and Cultural Rights (ICESCR), in the context of the right to housing. The Commission pointed out that as a Party to the Covenant, Sri Lanka undertook to "take steps, to the maximum of its available resources, to achieve progressively the full realisation of the rights recognised in the Covenant." It noted that General Comment 3 of the Committee on Economic, Social and Cultural Rights (CESCR), while acknowledging the constraints to realization due to the availability of resources also imposed obligations which are of immediate effect. Furthermore, General Comment 9 of CESCR required Parties to use all means at their disposal to give effects to the rights. General Comment 3 also requires States to provide the "minimum essential levels of each right." The Commission also cited General Comment 4 of CESCR on the right to housing. Therefore, the Sri Lankan Government is bound to take active steps to the maximum of its available resources to achieve the full realization of the rights.

\footnotetext{
98 In a subsequent decision (Sriyani Silva v. Iddalmagoda, Officer-in-Charge, Police Station, Payagala and Others [2003] 2 Sri L R 63), in which the substantive issues were considered, the Court held that the rights of the deceased had been infringed and that such rights had devolved upon or accrued upon the Petitioner and their minor child, who were awarded damages.

99 Locus standi before the Commission is more liberal than before the courts. Under Section 14 of the Act any person may bring a motion or complaint before the Commission on behalf of any other aggrieved person or persons.

100 The Urban Development Authority (Special Provisions) Act No. 44 of 1984.
} 
The Commission went on to hold:

As illustrated above, the recognition of the existence of minimum essential levels of each right means State parties cannot use the lack of adequate resources as justification for the realisation of Covenant rights. In this particular instance, by forcibly evicting the resident of Oliyamulla, the Sri Lankan State has violated its obligations under the ICESCR. It is, therefore, imperative that the Sri Lankan State recognise the right to housing and the need to recognise minimum essential levels of each right including the right to housing.

The Commission held that the Urban Development Authority had violated Sri Lanka's obligations under the ICESCR.

\section{NATIONAL LAWS ON INTERNATIONAL LAW MATTERS}

\section{Citizenship (Amendment) Act No. 16 of 2003}

The Citizenship Act of 1948 was discriminatory of women in that it did not permit a Sri Lankan woman married to a non-Sri Lankan man to pass on her nationality to her children, while permitting a Sri Lankan man married to a non-Sri Lankan woman to do so. Effectively, Sri Lankan nationality could be passed down only through the father.

Women's rights activists had campaigned for many years for this law to be amended, and the issue was also raised by the Committee on the Convention for the Elimination of All Forms of Discrimination Against Women in 2002 when Sri Lanka presented its combined Third and Fourth Report. In its Concluding Comments, the Committee expressed its concern at "the nationality law which precludes Sri Lankan women from passing nationality to their children on an equal footing with men."101 The Committee urged the State party "to review all existing laws and amend discriminatory provisions so that they are compatible with the Convention and the Constitution." 102

In 2003, the provisions regarding citizenship by descent were amended to eliminate the discrimination against women. Part II of the original Act entitled "Citizenship by descent" provided that a person born in or outside Ceylon (as it then was) could acquire citizenship if at the time of his/her birth, his/her father was a citizen of Ceylon. The amending law has amended that provision so that he/she may obtain citizenship "if either of his parents is or was a citizen of Sri Lanka."

\footnotetext{
101 Office of the High Commissioner for Human Rights - Concluding Observations of the Committee on the Elimination of Discrimination against Women: Sri Lanka - 07/05/2002 - A/57/38 (Part I) - Paragraph 274.

102 Ibid., Paragraph 275.
} 
Acquisition of citizenship through the mother has also been given retrospective application. A new provision, Section 5A, provides that a person born after the appointed date (15 November 1948) but before the date of commencement of the amending Act, and (1) whose mother only was a citizen of Sri Lanka or (2) neither of whose parents was a citizen at the time of his/her birth but one of them subsequently acquired citizenship, may apply for citizenship.

In other provisions of the Act too, the word "father" wherever it occurs has been substituted with the word "parents" or the words "father or mother".

\section{TAJIKISTAN ${ }^{103}$}

NATIONAL LAWS ON INTERNATIONAL LAW MATTERS

\section{State Guarantees - Equal Rights for Men and Women - Equal Opportunities in the Exercise of Such Rights}

\section{Law on State Guarantees of Equal Rights for Men and Women and Equal Opportunities in the Exercise of Such Rights Adopted 1 March 2005}

The Law on State Guarantees of Equal Rights for Men and Women and Equal Opportunities in the Exercise of Such Rights was enacted in Tajikistan to comply with its obligations following the ratification of the Convention on the Elimination of All Forms of Discrimination against Women. The preamble of the law stipulates that the legislation primarily focuses on securing constitutional guarantees for men and women in the social, political, cultural, and any other area, and is directed to prevent discrimination on the basis of gender.

General provisions provide terminological definitions of categories such as gender, gender policy, equality, gender equality, equal opportunities, and discrimination. The law defines equality as equality in the rights, obligations and accountability of both men and women before the law. As for the equality of opportunities: the law under this term entails the guarantee of conditions for the exercise of rights by men and women in accordance with the Constitution and laws of Tajikistan and international standards adhered to by Tajikistan. Discrimination is any distinction, exclusion or limitation on the basis of gender that is aimed at the abatement or nullification of the equality of men and women in the political, economic, social, cultural or any other spheres. Discrimination of men and women is prohibited. ${ }^{104}$ Violation of this

\footnotetext{
103 Contributed by Tahmina Karimova, Intern, International Criminal Court, The Hague.

104 Article 3 of the Law on State Guarantees of Equal Rights for Men and Women and Equal Opportunities in the Exercise of Such Rights accessed at legal database "Pravo i consultant".
} 
principle which is laid down as the foundation of gender equality, e.g., violation through enforcing state policy and other actions that place men and women in unequal positions, is considered discrimination and shall be eliminated in accordance with the provisions set by the law. ${ }^{105}$ The provisions of the law further spell out that special measures envisaged to protect the health of both men and women, and special protection afforded to women in relation to pregnancy and childbirth as well as other measures to implement the law, shall not constitute discrimination.

State authorities are obligated within their competence to ensure equal opportunities for both men and women in the following areas: ${ }^{106}$

- execute gender education of state officials by means of human resources training;

- promote and facilitate the exercise of equal opportunities by both men and women inter alia through adoption of legal instruments, and establishment of procedures and other specific measures including the elimination of causes and conditions preventing men and women from exercising the right to equality;

- develop and implement special programmes directed at the elimination of discrimination based on gender;

- introduce into state programmes measures aiming at ensuring constitutional rights and guarantees and reinforcing the stability of society, and measures to ensure gender equality.

The state guarantees equal participation of men and women in state governance. The state ensures equal representation of men and women in the legislature, executive, and judiciary through legal, administrative, and other mechanisms. ${ }^{107}$

The law, in addition to the general guarantees formulated in the form of principles, provides additional sets of guarantees under different sets of rights. Article 6 , in particular, regulates equal opportunities rights in the area of education. All educational and academic institutions are obligated to:

- ensure equal conditions for men and women to pursue general, vocational and professional education, all types of professional training and refresher courses;

- incorporate special gender courses to promote research in the area of gender equality, and assist citizens in their gender education;

- employ educational programmes and materials that exclude discrimination on the basis of gender;

105 Ibid.

106 Supra n. 99, Article 4.

107 Supra n. 99, Article 5. 
- set up preferential conditions of admission to secondary and higher professional education institutions for girls from mountainous regions and rural areas.

Chapter II of the law sets out provisions in Articles 8 and 9 on state guarantees of the equal opportunities of men and women in the exercise of their electoral rights. The provision of law in this regard states that the "electoral system of Tajikistan ensures equal electoral rights and guarantees and equal participation of both men and women in the political process". Equal opportunities guarantees for men and women in the formation of electoral commissions are set out in Article 9.

Chapter III standardizes state guarantees in the area of state civil service. The law provides that no direct and indirect restrictions or privileges on the basis of gender shall be permitted for entry into the state civil service system and for the length of such service. ${ }^{108}$ Furthermore, Article 10 stipulates that heads of state bodies and relevant state officials shall ensure equal access for all citizens to the state civil service in accordance with their abilities and professional qualification notwithstanding the gender of the candidate for the position. Vacancies shall be taken up following recruitment on equal conditions of participation for men and women. The provision concludes that vacancy announcements shall not be made solely for persons of either sex.

State guarantees on equal opportunities of men and women in social and economic spheres are laid down in Chapter IV. State agencies, municipalities, and heads of organizations of all forms of property are obliged to ensure that men and women have equal access to economic resources including immovable and movable properties, land, financial actives, and credits, and guarantee freedom of entrepreneurship and other types of activities in accordance with the laws of Tajikistan. ${ }^{109}$

In order to promote gender equality in labour relations, employers (head of a state agency or head of an organization) shall ensure

- equal opportunities for men and women regarding labour contracts;

- equal access of men and women to vacancies;

- equal remuneration for men and women having the same position or equal remuneration for men and women who perform work of equal value;

- $\quad$ safe labour conditions. ${ }^{110}$

Article 14 provides that in the case of a legal action on the ground of alleged sex discrimination against an employer by an employee, trade union or other public association, the burden of proof regarding the absence of malice (intention) lies with

108 Supra n.99, Article 10.

109 Supra n. 99, Article 12.

110 Supra n. 99, Article 13. 
the employer. In the case of a massive employee redundancy, the number of suspended employees of one gender shall be proportional to the general number of the staff involved in the specific object in question. ${ }^{111}$ Collective labour contracts should include measures providing equal rights and opportunities for men and women and should contribute towards improving conditions for men and women to combine their professional and family lives. ${ }^{112}$ The monitoring mechanisms in this regard are vested in trade unions, other representatives of employees, union of employers, and relevant state authorities.

Admittance to work, promotion, re-training, the setting-up of the work schedule, and dismissal shall be carried out in accordance with the requirements of the law on equal rights and opportunities for men and women and with due consideration of their family situation. Employers are obligated to have a system of retraining for employees of both genders related to vacations permitted by laws, the birth and bringing up of a child, military service, and other state service-related assignments. ${ }^{113}$

Article 17 stipulates the implementation of the monitoring of equal rights and opportunities in the area of economic and social life. In accordance with the provision of this article, an authorized body shall organize continuous monitoring of the implementation of equal rights and opportunities for men and women. The monitoring shall be organized, inter alia, for the purposes of the systematic analysis of the exercise of equal rights and opportunities for men and women in social and labour areas, the forecasting of changes to the current situation in order to evaluate whether measures are needed to prevent and impede facts of gender-based discrimination, and for the purpose of the development of proposals on state social programmes in the area of concern. Results of the monitoring shall be reflected in the mass media. ${ }^{114}$

Chapter V provides for a general monitoring mechanism to ensure the implementation of equal rights and opportunities for both men and women. The Government defines the following measures within its mandate to ensure the exercise of equal rights and opportunities:

- the establishment of a state body on gender development in Tajikistan;

- the development of a unified state policy aimed at the achievement of the social equality of men and women in all areas of state and public lives, and to ensure the implementation of such a policy;

- the development of target (subject area) programmes and their implementation to promote the equality of men and women;

111 Supra n. 99, Article 15.

112 Supra n. 99, Article 16.

113 Supra n. 99, Article 7.

114 Supra n. 99, Article 17. 
- the direction and control of executive bodies and municipalities on the protection and exercise of equal rights of men and women, the appointment of women in authoritative positions, and the education of the young generation of key staff from among women. ${ }^{115}$

The participation of trade unions and public associations in the implementation of equal rights and opportunities is confined to the process of decision making in economic and social spheres, and to the representation and protection of the rights of men and women in accordance with Article 20 of the law. The general monitoring of precise and unified implementation of laws and other normative instruments ensuring equal rights and opportunities for men and women in exercise of such rights is vested in the Office of General Prosecution of Tajikistan. ${ }^{116}$

\section{Fight against Corruption}

\section{Law on the Fight against Corruption Adopted 25 July 2005}

The introductory part of the Law on the Fight against Corruption lays down that the law sets out a legal framework aimed at the protection of human rights and freedoms, ensuring public interest, national security, good governance, integrity, and impartiality in the state and public service; it also sets out the legal and administrative framework for preventing, investigating, and reducing the consequences of violations related to corruption. In addition, the law envisages the types of violations and punitive measures related to corruption. This is the second anti-corruption law adopted by Tajikistan. The previous legal instrument failed to incorporate some important principles set by international standards in the fight against corruption.

Under the new law, corruption is defined as the (in)actions of persons authorized to fulfil Governmental functions or equivalent persons using their position and related opportunities to gain material and non-material benefits and advantages not envisaged by law, and other advantages for himself or herself or another person, as well as promising, offering or giving the aforementioned persons (public officials or equivalent persons) advantages in order that the public official or the person abuse his or her real or supposed influence with a view to obtaining an advantage for individuals or legal entities. ${ }^{117}$ The new definition of corruption has attempted to integrate practically all international standards concerning the definition of "corruption". Furthermore, under the new law, the definition of corruption includes, in addition to "material gains" (as stipulated by the previous law), "non-material gains" and "benefits", "promises and offers", thus introducing the concept of "trade of

\footnotetext{
115 Supra n. 99, Article 18.

116 Supra n. 99, Article 21.

117 Article 1 of the Law on the Fight against Corruption, accessed at legal database "Pravo i Consultant".
} 
influence" as opposed to the previous legal standards in the area. The law also provides a comprehensive definition of a "state official". ${ }^{118}$ The new law also criminalizes the bribery of legal entities and of foreign or international public officials. $^{119}$

Under the new law, state authorities predominantly involved in the fight against corruption are the office of prosecution, internal affairs, security, military service, border control, drug control, and tax and customs agencies. The Office of the Prosecutor has the coordinating role among the state authorities. ${ }^{120}$ Furthermore, the Prosecution is mandated with the implementation of analytical activities and statistical monitoring of anti-corruption activities in Tajikistan.

Article 6 provides for the protection of those who cooperate with state agencies in the detection of corruption. While international standards in this area specifically mention two categories of witnesses and whistleblowers, Tajik legislation in this regard provides for the concept of "persons cooperating" as an addition.

The Law on the Fight against Corruption imposes special requirements and restrictions on those who hold a state office as a measure to prevent abuse of official status or use of influence for personal, group or other unrelated purposes deriving from an official status. ${ }^{121}$ Therefore, in accordance with the law, state officials declare their income to tax authorities on an annual basis. A person may not be selected, appointed or hold a state office if:

- he or she is sentenced for a deliberate crime (unless such a crime has been expunged or cancelled in accordance with the law);

- he or she is declared incapable or limitedly capable by decision of a court;

- he or she is declared incapable due to lack of education, professional skills and necessary experience if such criteria be deemed necessary by the laws of Tajikistan;

- he or she is in direct subordination to or reporting to posts held by close relatives;

- he or she is a citizen of a foreign country unless such an arrangement is provided by an international agreement adhered to by Tajikistan. ${ }^{122}$

A person holding a state or public office must follow additional restrictions. $\mathrm{He}$ or she may not:

118 Ibid.

119 Supra n. 112, Article 3.

120 Supra n. 112, Article 5.

121 Supra n. 112, Article 7.

122 Supra n. 112, Article 9. 
- occupy another paid post apart from those related to academic, artistic and teaching jobs;

- participate in entrepreneurial activities personally or through third parties;

- make use of financial, technical, material and other state or public means and resources, as well as corporate information, for purposes not related to the occupying post;

- accept rewards for services provided within functional duties, gifts and the provision of out-of-office services to senior staff with the exception of symbolic presents and souvenirs provided in the course of an official event;

- undertake tours and health-related travels at the expense of individuals and legal entities both domestic and foreign with the exception of travels supported by close relatives and travels provided for by international treaties and agreements concluded among relevant Tajik and foreign state authorities;

- perform the orders and requests of political parties, public associations, religious organizations and use official position for their interests;

- communicate regionalism or prejudice contrary to the interest of the work or favour organizations, public associations or a specific individual;

- receive honorariums for publications and speeches at official events transmitted by radio and television that are part of the service performed in the official post. ${ }^{123}$

A further provision stipulates that violation of aforementioned restrictions shall be subject to legal responsibility provided in Chapter III which reflects issues of violations related to corruption and accountability for such offences. In this regard, the law distinguishes two types of offences: 1) offences creating conditions for corruption, and 2) administrative offences related to corruption. The offences relevant to the first category and committed by individuals authorized to perform state functions are as follows: ${ }^{124}$

- use of official status to resolve issues related to personal interests, close relatives and third persons;

- impede or illegally interfere in law enforcement or controlling activities in a specific territory in relation to specific objects or persons;

- participation in the capacity of chargé d'affaires of individuals and legal entities in relation to cases of an agency he or she is being employed by, or subordinate to or supervised by;

- participation in gambling or games of material character with senior, junior or other work-related staff;

- entrepreneurship, participation in entrepreneurial organizations or in their governing bodies;

124 Supra n. 112, Article 11. 
- provision of advantages (protectionism) not envisaged by laws in appointment and promotion in state service, in education, academic or any other similar activity;

- violation of public complaint procedure set by the laws of Tajikistan, disregard of advantages, subventions or rotation provided by laws in resolving such complaints;

- delegation of authority in the area of state regulation or control of entrepreneurship to individuals or legal entities engaged in such an activity.

Administrative offences related to corruption are reflected in Article 12 of the law and present a very comprehensive list of actions that do not contain criminal elements and, therefore, are considered violations of an administrative nature. Article 14 of the Law refers to the Criminal Code of Tajikistan as regards the definition of the crimes of corruption and liability for the commission of such crimes.

The last substantive part of the law, Chapter V, deals with the confiscation of property and annulment of normative acts. In accordance with Article 15, the property and value of services received as a result of a violation related to corruption are subject to confiscation in accordance with the relevant laws and rules of Tajikistan. As for normative acts adopted as a result of violation related to corruption, they are required to be annulled by the decision of an official or collegial body authorized, or by court or by the objection of the prosecutor.

\section{OTHER RELEVANT STATE PRACTICE}

\section{State Military Policy}

\section{Military Doctrine of Tajikistan Adopted 3 October 2005}

The Military Doctrine of Tajikistan is a compilation of the official views that determine the military, political, strategic and economic bases for military security in Tajikistan. ${ }^{125}$ The document spells out that the present doctrine is a transitional outcome, since it determines directions at the stage of democratic state building, transitional economy, re-organization of the military system, and the dynamic transformation of international relations. The Military Doctrine develops and concretizes the concept of the national security of Tajikistan.

The political and military foundations of the Doctrine are set out in Chapter II. This part of the Doctrine acknowledges the danger an armed conflict may pose Tajikistan and the Central Asian region as a whole. Hence, taking into consideration

\footnotetext{
125 Chapter I of the Military Doctrine of the Republic of Tajikistan accessed at legal database "Pravo i Consultant".
} 
this perspective, this part of the Doctrine determines the following fundamental principles:

- It is indispensable to abide by principles of peaceful coexistence, use political means to find solutions to regional and international disputes and conflicts, respect the sovereignty and territorial integrity of other countries, not interfere in internal affairs, and maintain the integrity of state borders;

- It is crucial to avoid wars, and to refrain from usage of armed violence and the threat of use of force for achievement of political, economic and other goals;

- It is important to condemn acts of terrorism, political extremism, separatism, and drug trafficking.

The Doctrine further stipulates that military power remains significant for the protection of the territorial integrity and sovereignty of Tajikistan from international terrorism, political extremism, separatism, and drug smuggling. In addition, military power is a means to prevent interference by other states in the internal affairs of Tajikistan. Therefore, Tajikistan reserves a right to ensure the security of its interests and the right of self-defence and collective defence in the case of the threat or use of force against Tajikistan and its allies in accordance with the Charter of the United Nations.

Section I of the Doctrine provides the political principles and means to ensure state security. In ensuring its security, Tajikistan will give priority to political, diplomatic and other peaceful means. Tajikistan refrains from animosity and the threat or use of force in its policy towards other states, and abstains from territorial claims as regards neighbouring states. According to the Doctrine, Tajikistan promotes further development of the rules of international law, supports the development and adoption of complex means and actions on military and technical issues by all states, and promotes the prevention of armed conflicts in the potential areas of violence outbreak.

Aiming at the preservation of national and international security and the prevention of different types of threats, Tajikistan will strive for:

- de-escalation of the arms race in the region and debarment of its transportation to outer space;

- a ban on the placement and nuclear testing in its territory;

- dismantling of nuclear, chemical, and biological weapons;

- a ban on the export of (transfer) materials and equipment facilitating the creation and proliferation of any type of weapon of mass destruction and means of its delivery;

- the steady reduction of the armed forces to the level necessary for defence by all states, in particular, Central Asian states;

- mutual respect, transparency, and preparedness in military activities and on this basis, create effective measures of trust and control; 
- timely information sharing among countries of the Central Asian Region, the Commonwealth of Independent States, the Collective Security Treaty Organization (CSTO), and the Shanghai Security Organization in preventing trans-national conflicts, and fighting with drug criminality, international terrorism, and extremism in all its forms and manifestation;

- the transformation and integration of existing military and political unions into more effective structures of collective security.

The policy of Tajikistan in the area of diminution and restriction of weapons as an element of international security is built upon the following principles:

- Priority is given to ensure the security interests of Tajikistan with due consideration for the security of other countries;

- Support to strategic stability in countries neighbouring Tajikistan and its strategic partners.

Tajikistan cooperates with all countries to strengthen international and national stability and security. It struggles for the prevention of armed conflicts in the region by means of integration into a system of collective security and the coordination of international efforts in this area. Peace and stability shall be achieved by peaceful means. On a regional basis, peace and stability shall be pursued on the level of states members of the Collective Security Treaty Organization, Shanghai Cooperation Organization, and states parties to the Commonwealth of Independent States. On a global level, Tajikistan will strive for peace and security with all those countries which are members of the United Nations Organization. These efforts shall be directed, in particular, at strengthening the world community in its fight against new challenges and threats to security from terrorism, drug dealing, and religious extremism.

Cooperation in the prevention of armed conflicts shall be carried out with all countries of the world community where the policies of cooperating states do not contravene the interests of Tajikistan and do not breach the UN Charter or its principles.

Section III of the Military Doctrine provides a background for the causes of potential and existing conflicts, factors and current challenges to security in relation to the Central Asian Region. The text, inter alia, states:

[D]espite the positive changes in the world in some separate regions, in particular, in the Central Asian region, social, political, economic, territorial, regional, and ethnic tensions are increasing; there are cases of international terrorism, religious extremism, proliferation of drugs and illegal migration that are the main causes of military insecurity not only for Tajikistan but also for all countries in general. Accumulation of these contradictions may bring about conflicts and local wars that directly concern the national interests of Tajikistan and its security. 
Factors contributing towards military danger include or may include:

- disparate economic development of states in the region in the period of transition to the new market economy relations and the acceleration of the social and economic stratification process of population;

- maintenance and growth of regional, ethnic and religious contradictions destabilizing situations both inside the country and in the Central Asian Region in general;

- internal armed conflicts;

- the growth of the drug business, international terrorism, extremism, and illegal migration;

- the tendencies of separate counties to establish their exceptional military and political influence in the Central Asian region and their inclination to resolve conflict situations by forceful means;

- the creation of massive violent/armed groups and military bases in the countries bordering with Tajikistan;

- territorial claims to Tajikistan.

A separate section is dedicated to the political aims of Tajikistan and provides a set of rules applicable to the use of force in conflict situations.

According to the document, the political aim of Tajikistan is to maintain and safeguard the constitutional rights of its citizens, protect its population, sovereignty, territorial integrity of the country, and the re-establishment and development of peace and friendly relations with all countries of the world.

In the case of violence or an armed conflict between the countries of the Commonwealth of Independent States or internal conflicts in these countries, Tajikistan will strive firsthand to achieve cease-fires and to resolve conflicts by diplomatic or other non-military means. Armed force can be used only in very exceptional cases on the basis of special decisions undertaken by the Council of Head of States of the Commonwealth of Independent States or the Collective Security Council of the Collective Security Treaty in order to support stability and create the conditions for the peaceful resolution of conflicts. Tajikistan recognizes the legality of the use of force for the following objectives:

- collective defence within the framework of bilateral or multilateral treaties with other countries;

- the maintenance and building of peace in accordance with the decisions of the UN Security Council and other structures of collective security, if not in contradiction with the vital interests of Tajikistan.

The use of the armed forces and other military structures of Tajikistan shall be carried out in exceptional cases as defined by the Constitution of Tajikistan and other laws in force or by the decision of the parliament. 
Furthermore, the Doctrine defines the characteristics of contemporary armed conflicts, e.g., armed conflicts nowadays are defined by their military and political aims, means of achievement of objectives and scope of military actions. The Doctrine provides that an armed conflict may be in the form of a military incident, armed action or other armed conflicts of limited scope, and may be as a result of an attempt to resolve economic, national, ethnic, religious, or other contradictions by means of armed force. The Doctrine further specifies that a cross-border conflict constitutes a special type of an armed conflict. An armed conflict is characterized by the following:

- the vulnerability of the population;

- the involvement of irregular armed structures;

- the vast usage of sabotage and terrorist methods;

- a complex moral and psychological environment in which armed forces are operating;

- the forced diversion of significant forces, provision of security means for areas and dislocation of armed forces;

- the danger of the transformation of a local armed conflict into an international one.

Moreover, the document sets rules on the dislocation, types, and nature of armed forces of Tajikistan, as well as providing principles by which the armed forces of Tajikistan are ruled.

The Doctrine elaborates the tasks of the State in the area of state defence as well as envisioning the purpose and missions of the armed forces of Tajikistan. These features are reflected in the relevant provisions of chapters dedicated to defence construction, training of armed forces, means and methods of defence, military leadership and cooperation on military issues. The concluding section of the Military Doctrine provides that cooperation of Tajikistan in this area is built upon collaboration with other countries for the prevention of armed conflicts and maintenance of the peace and security as well as the defence of the country, and such cooperation shall be carried out in accordance with the United Nations Charter.

\section{Humanitarian Cooperation}

\section{Declaration of Commonwealth of Independent States (CIS) countries on Human- itarian Cooperation}

\section{Adopted 8 May 2005}

On 8 May 2005, Tajikistan, Azerbaijan, Moldova, Armenia, the Russian Federation, Byelorussia, Georgia, Turkmenistan, Kazakhstan, Uzbekistan, Kyrgyzstan, and Ukraine signed a joint declaration on humanitarian cooperation in areas including culture, 
national traditions, languages, science, education, archives, information, communication, sports, tourism, and youth development. Cooperation and development in the aforementioned areas are deemed by the Declaration as the main component of the integration process in the territory of Commonwealth of Independent States. Humanitarian cooperation shall be organized based on good practice and the principles of relevant international organizations, including UNESCO. The document underlines the determination of CIS countries to further develop modules and mechanisms of cooperation in these areas through the conclusion of a general agreement. 